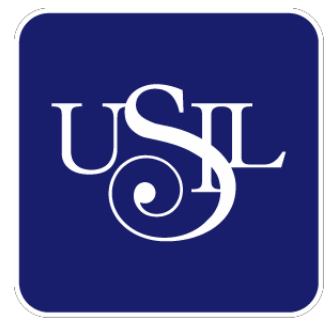

UNIVERSIDAD

SAN IGNACIO

DE LOYOLA

FACULTAD DE HUMANIDADES

Carrera de Arte y Diseño Empresarial

\title{
ANÁLISIS DE LA PÉRDIDA DE JUEGOS INFANTILES COMO TRADICIONES CULTURALES QUE GENERAN UN SEDENTARISMO TECNOLÓGICO EN NIÑOS DE 10 A 12 AÑOS PERTENECIENTES A LOS SECTORES SOCIOECONÓMICOS C Y D DE LIMA METROPOLITANA
}

Tesis para optar el Título Profesional de Licenciado en Arte y Diseño Empresarial

ISMAEL JOSUÉ LEÓN MATOS

Asesor:

Mg. Rafael Ernesto Vivanco Álvarez

Lima - Perú

2019 


\section{Dedicatoria}

Le dedico esta tesis a Brillyt, Luz María, Fiorella, Diego, Andrea, Karina,

Chicho, Zayra, Yamileth, María Inés y Perolo: mis amigos de la infancia.

Gracias por las tardes de verano jugando matagente, 7 pecados, kiwi y sobre todo mi juego preferido: las escondidas.

Gracias a la vecina Pacasi por ser la encargada de refrescarnos luego del juego con sus deliciosos marcianos de fruta.

Y una dedicatoria especial a la vecina María, por siempre amenazarnos de reventar la pelota cada vez que caía a su jardín. Gracias por nunca llegar a romperla.

Sin ustedes mi infancia no hubiese sido la misma. 
Agradecimientos

Deseo agradecer a mi mamá por apoyarme desde la emoción, y a mi papá por apoyarme desde el raciocinio. Gracias a mi hermana Karina por brindarme una mano, un cartón y una cuchilla cuando más lo necesitaba.

Gracias a mis abuelitos desde el cielo. A mi abuelito Ismael, por haberme contado desde niño sus amanecidas trabajando, me inspiraste a que todo esfuerzo tiene su recompensa. A mi abuelita Margarita por enseñarme a ayudar al que más lo necesita, la solidaridad hacía el prójimo fue clave en este proceso. A mi abuelito Daniel, gracias por heredarme tu vena artística y a mi Litis, gracias por enseñarme a ver el lado humorístico y optimista de las cosas. Sin coraje, solidaridad, talento y optimismo no hubiese podido desarrollar esta tesis con tanta plenitud.

Gracias a todos los que colaboraron para que este proyecto sea exitoso. Hablar con cada uno de ustedes sobre los juegos infantiles tradicionales hizo que se les esbozara una sonrisa en el rostro. Nunca olviden a su niño interior.

Gracias. 
ANÁLISIS DE LA PÉRDIDA DE JUEGOS INFANTILES COMO TRADICIONES CULTURALES QUE GENERAN UN SEDENTARISMO TECNOLÓGICO EN NIÑOS DE 10 A 12 AÑOS PERTENECIENTES A LOS SECTORES SOCIOECONÓMICOS C Y D DE LIMA METROPOLITANA 


\section{ÍNDICE}

\section{Resumen}

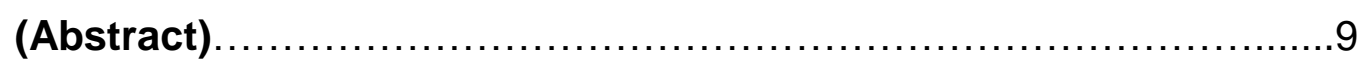

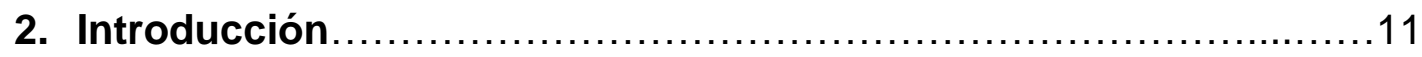

\section{CAPÍTULO I}

3.1. Descripción del problema encontrado.............................12

3.2 Problema principal...............................................

3.3 Problemas secundarios.........................................

\section{CAPÍTULO II}

4.1. Justificación de la investigación...............................14

4.2 Objetivo principal...............................................

4.3 Objetivos secundarios...........................................

\section{CAPÍTULO III}

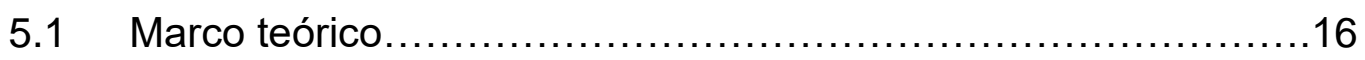

A. Tradición.....................................................

a. Definición............................................. 16

b. Contextos................................................ 17

i. Tradición en la sociología........................17

ii. Tradición en la etnología...........................19

iii. Tradición en la historia..........................20

iv. Tradición en la jurisprudencia....................20

v. Tradición en la filosofía..........................20

c. Tradiciones culturales................................21

i. Tradición cultural verbal............................23

ii. Cultura material................................... 24

d. Importancia de las tradiciones culturales...............25

e. Tradiciones en el Perú...................................26

i. Tradiciones festivas.............................. 27

ii. Tradiciones culinarias..........................29 


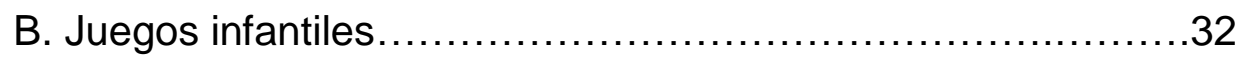

a. Tradicionales................................................ 33

i. Teoría del juego infantil............................33

ii. Importancia del juego infantil.......................35

iii. Juegos infantiles clásicos...........................36

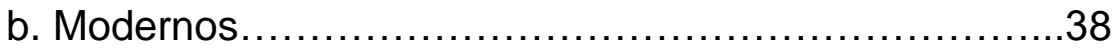

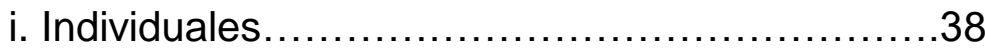

ii. Colectivos.......................................... 38

C. Seguridad ciudadana y la calle

a. Cómo influencia la seguridad y jugar en la calle..........41

D. Lima ........................................................ 42

a. Barrios populares.................................... 43

b. Contexto social en los barrios populares.................43

E. Comunicación personal........................................

a. Comunicación tradicional...................................44

i. Teoría de la comunicación..............................47

ii. Tipos de comunicación...............................47

b. Comunicación tecnológica....................................51

i. Características...................................53

ii. Beneficios............................................54

iii. Desventajas.................................... 54

c. Los niños y las tecnologías de comunicación.............55

F. Teléfonos móviles y entretenimiento digital......................56

a. Smartphones..........................................56

i. Características........................................57

ii. Ventajas y desventajas..........................57

b. Tablets...................................................... 59

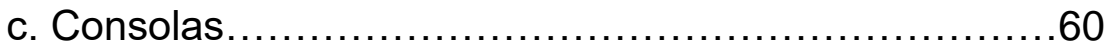

d. Problemas generados a causa del mal uso de la tecnología.....................................................61

i. Físico ..................................................

ii. Emocional................................................64 
iii. Relación entre la tecnología y el comportamiento

en niños de 9 a 10 años .65

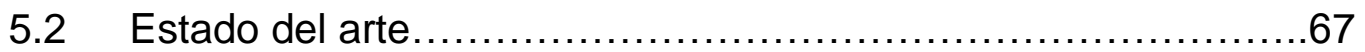

A. Antecedentes nacionales....................................... 67

B. Antecedentes internacionales...................................69

6. CAPÍTULO IV

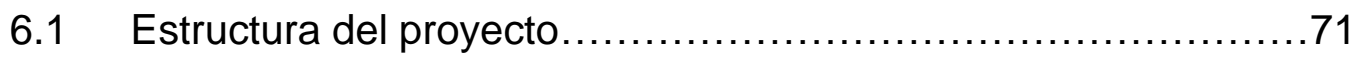

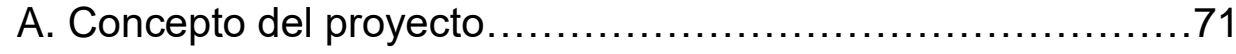

B. Nombre del proyecto................................................

C. Fundamentación del proyecto.....................................72

6.2 Público objetivo.................................................. 73

A. Actores involucrados en el problema............................73

B. Fundamentación del público objetivo elegido....................75

C. Descripción del público objetivo elegido...........................75

\section{CAPÍTULO V}

7.1 Análisis del diseño
A. Simbolismo. .75
B. Pragmatismo. .76
C. Estética. .77
D. Sintaxis. .77

7.2 Diseño de la comunicación

\section{CAPÍTULO VI}

8.1 Análisis de los resultados

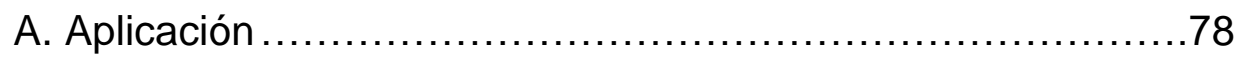

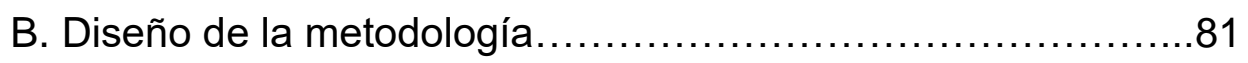

C. Evaluación de la metodología........................................ 83

D. Registro de la implementación.......................................84

F. Documentos que acrediten.......................................92

\section{CAPÍTULO VII}

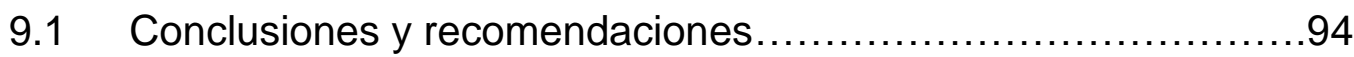

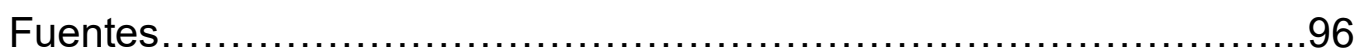




\section{Resumen}

Los yaces, las escondidas, las chapadas y el mata gente son algunos juegos infantiles tradicionales, transmitidos de generación en generación, los cuales lamentablemente están desapareciendo poco a poco.

Los acelerados cambios tecnológicos y culturales han afectado profundamente la manera en que los niños viven y pasan su tiempo libre. Por diversas razones, estamos experimentando una fuerte caída de la actividad que mejor define la infancia: el juego al aire libre.

La tecnología digital ciertamente ofrece buenas oportunidades educativas, pero a su vez reduce la capacidad de estimular, imaginar y crear del niño. El uso excesivo de dispositivos digitales reduce su capacidad de concentración, haciéndola dependiente de la híper-estimulación, promoviendo así un sedentarismo tecnológico.

El rescatar estos juegos de antaño es necesario para el desarrollo de la interacción social del niño permitiendo la socialización y estimulación para una sana convivencia. 


\section{Abstract}

Knucklebones, Hide-and-seek, Tag, and Dodge ball are some traditional children's games, transmitted from generation to generation, which unfortunately are disappearing through the time.

Technological and cultural changes have profoundly affected the way children live and spend their free time. For various reasons, we are experiencing a sharp drop in the activity that best defines childhood: outdoor play.

Digital technology certainly offers good educational opportunities, but in turn reduces the ability to stimulate, imagine and create the child. The excessive use of digital devices reduces their capacity for concentration, making it dependent on hyper-stimulation, thus promoting a technological sedentary lifestyle.

Rescuing these traditional games is necessary for the development of social interaction of the child allowing socialization and stimulation for a healthy coexistence. 


\section{Introducción}

El juego, a pesar de estar estrechamente ligado a la infancia y a los niños, siempre ha sido una actividad significativa en la vida de los hombres en diferentes épocas y lugares. Está marcado por la continuidad y el cambio, por no ser simplemente reproducido, sino recreado a partir de lo que el niño trae de nuevo con su poder de imaginar, crear, reinventar y producir cultura. Por lo tanto, jugar es una experiencia de cultura importante no sólo en los primeros años de la infancia, sino durante todo el recorrido de vida de cualquier ser humano. Al jugar, se aprende el lenguaje de los símbolos y se entra en el espacio original de todas las actividades sociales y culturales, atribuyéndoles nuevos significados.

Antes el niño solía ser visto como un ser marcado por la ingenuidad y la ignorancia, cuyo desarrollo dependía estrictamente del adulto, hoy por hoy asume el lugar de protagonista, blanco preferente de la sociedad de consumo; si antes la familia y la escuela eran instituciones privilegiadas para la socialización de los niños, hoy ellas cuentan con el aporte de los medios electrónicos, con la que han interactuado diariamente. En este contexto, el mundo contemporáneo, marcado por la falta de espacio, por la prisa, la influencia de los medios, el consumismo y la violencia, se acaba reflejando en la forma en que los niños juegan.

Hace menos de tres décadas la gran mayoría de las relaciones amicales ocurrían entre amigos de un mismo barrio, niños del mismo edificio o colegio. Solían pasar el tiempo juntos para distraerse, jugar e intercambiar experiencias. Los juguetes necesitaban de una gran dosis de imaginación. Las calles eran ambientes un poco más seguras, con menos flujo de vehículos, lugar ideal para todo tipo de juegos. En los últimos años, sin embargo, la experiencia del juego ha cambiado radicalmente. Los juegos infantiles tradicionales están tan olvidados que muchos niños ni siquiera los conocen. Estos juegos, transmitidos de generación en generación, como mundo, saltar la liga, las escondidas y las chapadas, están siendo reemplazados por juegos electrónicos, los cuales se pintan como atractivos. Los niños de hoy viven una especie de insatisfacción permanente, pues es cada vez más difícil acompañar el ritmo del juguete o del juego que está de moda, debido a su velocidad de actualización. 
El internet es un medio importante para la evolución humana, sin embargo, cabe reconocer que así como viene ampliando la capacidad de interacción social de forma virtual, también viene reduciendo esas mismas capacidades presencialmente. Incluso viviendo inmersos en nuevas tecnologías se considera necesario recordar que los juegos colectivos son de gran valor para el desarrollo de la interacción social del niño.

El juego debe tomarse en serio, aplicando todas las edades. Lo que antes era tan simple y natural en los niños, hoy necesita ser estimulado. Además de construir conocimiento y dar sentido al mundo, es en el juego, que el niño resuelve problemas, lidia con reglas, interactúa con otros niños, explora diferentes movimientos y amplía las posibilidades comunicativas. Por estos motivos, jugar al aire libre es parte fundamental del desarrollo infantil. 


\section{CAPÍTULO I}

\subsection{Descripción del problema encontrado}

Actualmente no es difícil encontrar niños usando smartphones, viendo videos en tablets o jugando a videojuegos por horas. Hoy por hoy hay una gran facilidad en obtener dispositivos electrónicos. La pregunta es ¿Hasta qué punto es saludable que un menor de edad pase el día hipnotizado frente a una pantalla? Según el "New York Times ", los jefes y empleados de compañías como Google, Apple, Yahoo y Amazon, inscriben a sus hijos en escuelas que prohíben el uso de computadoras, teléfonos celulares o cualquier otra tecnología portátil. Esta actitud se basa en estudios recientes, que muestran cómo la conectividad puede causar daños tanto físicos como emocionales a los niños.

La psicóloga educativa Lic. Marisol Medina defiende que los menores de 12 años no deben tener contacto con smartphones, tablets y otros aparatos tecnológicos, pues los mismos son perjudiciales para el desarrollo y el aprendizaje infantil. El niño tiene que saltar, correr, gastar energía. Medina toca otro punto muy común: la mayoría de papás tienen pereza de jugar con los niños. "Muchos padres no interactúan con sus hijos, no participan en la infancia, no juegan juntos. El Internet no puede ser más importante que interactuar socialmente con tus propios hijos", enfatiza.

Cuando no existían tablets y smartphones, ¿cómo hacían los padres para entretenerse cuando eran niños?: Jugar al aire libre. Los juegos tradicionales, como las chapadas, las escondidas, los yaces, son juegos que existen desde hace siglos. La pregunta es: ¿Por qué se están perdiendo ahora?

\subsection{Problema principal}

La pérdida de juegos infantiles como tradiciones culturales que generan un sedentarismo tecnológico en niños de 10 a 12 años pertenecientes a los sectores socioeconómicos C y D de Lima Metropolitana

\subsection{Problemas secundarios}

Obesidad causada por la pérdida de juegos infantiles como tradiciones culturales que generan un sedentarismo tecnológico en niños de 10 a 12 años pertenecientes a los sectores socioeconómicos C y D de Lima Metropolitana. 
Falta de comunicación interpersonal debido a la pérdida de juegos infantiles como tradiciones culturales que generan un sedentarismo tecnológico en niños de 10 a 12 años pertenecientes a los sectores socioeconómicos C y D de Lima Metropolitana. 


\section{CAPÍTULO II}

4.1. Justificación de la investigación

Los yaces se inventaron en la Antigua Grecia (David, 1998), el mundo o rayuela era muy popular en el siglo XVII (Shadwell, 1668), los pequeños romanos jugaban con canicas antes de la llegada de Cristo (González, 2010). Sin embargo estos juegos se comenzaron a extinguir rápidamente, siendo burlado sus años de experiencia. La llegada de la era digital acarrea un cuestionamiento que se enfoca en la relevancia de las tradiciones culturales en este nuevo siglo.

Por otro lado, ¿tiene la madurez suficiente un niño de 10 años para tener un smartphone? Un estudio de publicado por la revista estadounidense The Lancet reveló que niños de 8 a 11 años pasaban 3,6 horas al día usando dispositivos para jugar a videojuegos, ver videos y en otras diversiones. Estos resultados son "un motivo de preocupación", afirma el fisiólogo Jeremy Walsh. El investigador también vincula la cantidad de tiempo que pasan los menores con sus dispositivos móviles a sus capacidades intelectuales.

A través de sus vínculos culturales, los juegos tradicionales tienen un impacto en reforzar la identidad, un factor de resiliencia. Participan activamente en el bienestar de los niños haciéndoles sentir que pertenecen a un grupo, una comunidad y una historia colectiva. La versión adaptada de un juego tradicional debe preservar tanto como sea posible sus raíces culturales y sus antecedentes básicos. Sin embargo, la historia se modifica cuando es necesario, para crear nuevas dinámicas que tengan en cuenta ciertos aspectos importantes de las actividades psicosociales, como abandonar todas las formas de exclusión e individualismo y promover la cooperación y participación.

\subsection{Objetivo principal}

Analizar la pérdida de juegos infantiles como tradiciones culturales que generan un sedentarismo tecnológico en niños de 10 a 12 años pertenecientes a los sectores socioeconómicos C y D de Lima Metropolitana

\subsection{Objetivos secundarios}

Prevenir la obesidad causada por la pérdida de juegos infantiles como tradiciones culturales que generan un sedentarismo tecnológico en niños de 10 
a 12 años pertenecientes a los sectores socioeconómicos C y D de Lima Metropolitana.

Advertir la falta de comunicación interpersonal debido a la pérdida de juegos infantiles como tradiciones culturales que generan un sedentarismo tecnológico en niños de 10 a 12 años pertenecientes a los sectores socioeconómicos C y D de Lima Metropolitana. 


\section{CAPÍTULO III}

\subsection{Marco teórico}

\section{A. Tradición}

\section{a. Definición}

La palabra tradición se define como la "transmisión de noticias, composiciones literarias, doctrinas, ritos, costumbres, etc., hecha de generación en generación" (RAE, 2018). Una tradición se considera como una creencia o comportamiento trasmitido a un grupo o sociedad con un significado simbólico y/o especial. Cabrera de Córdova (1611) sostiene: "De la tradición, según esto es hija la historia, y la escrita que primero fue vocal, y lo son todas, pues tradición es narración, opinión y doctrina derivada vocalmente, sin haber escrito, con el uso de padres a hijos, y de los que vieron las cosas, a los que no las vieron". Ejemplos comunes de estas tradiciones incluyen días festivos o trajes típicos, también aplican normas sociales como saludar.

La palabra tradición deriva del Latín traditio, que significa trasmitir, entregar. Fue originalmente usado en la antigua Roma para referirse al ámbito de transferencias legales y herencias. Según Anthony Giddens (1999) el significado tradición en la llustración tuvo una connotación contrapuesta a modernidad y progreso.

El término tradición también se asocia a creencias, objetos o costumbres desarrolladas o establecidas en el pasado, originadas y trasmitidas a través del tiempo, de generación en generación hasta la actualidad.

Originalmente las tradiciones fueron trasmitidas oralmente, sin necesidad de un sistema escrito. Las herramientas que ayudaban a este proceso incluyen sistemas poéticos como la rima y la aliteración. Las historias preservadas de esta manera también se conocen como tradición, o como tradición oral, sin embargo, estas también pueden ser adaptadas dependiendo de las necesidades de la época, y los cambios que estás acarran conllevan a que la tradición sea aceptada y modificada. Esto último es un proceso que se genera lentamente, aquellos que llevan a cabo las tradiciones no serán conscientes del cambio, e incluso si una tradición experimenta cambios importantes durante muchas generaciones, se verá como si estos cambios necesarios no hubiesen sido modificados nunca. 
Existen varios campos y orígenes a los que el término tradición puede ser referido:

1. Las formas del patrimonio artístico de una cultura en particular.

2. Creencias o costumbres instituidas y mantenidas por sociedades y gobiernos.

3. Creencias o costumbres mantenidas por denominaciones religiosas y cuerpos eclesiásticos que comparten historia, costumbres, cultura y enseñanzas.

Muchos objetos, creencias y costumbres pueden considerarse como tradicionales. Rituales e interacciones sociales pueden ser tradicionales también, con frases y gestos como un "muchas gracias", dar saludo de cumpleaños, etc. Tradiciones también se consideran actos y conceptos practicados por determinados grupos, como tradiciones navideñas. Alguna de las tradiciones más antiguas incluye el monoteísmo (tres milenios) y la ciudadanía (dos milenios).

\section{b. Contextos}

\section{i. Tradición en la sociología}

Dado que la tradición es uno de los fundamentos de la vida social y el comercio, la sociología en particular se ha ocupado del fenómeno de la tradición, Robert Spaemann (1952) ve en el tradicionalismo francés una de las raíces de la sociología misma. El análisis sociológico de la tradición ha dado forma a las humanidades y los estudios culturales. Particularmente la comprensión de la tradición hecha por el sociólogo Max Weber se define como uno de los cuatro tipos básicos de acción social que nunca se deben sobreestimar. Weber distingue la orientación a la tradición del propósito y la orientación de la acción basada en el valor racional. "La acción estrictamente tradicional va más allá de lo que se puede llamar una acción significativa "orientada". (Weber, 1920). Esta tradición contrasta la tradición pre-racional y la modernidad orientada a finales del siglo XIX. Así mismo esta yuxtaposición es también el resultado de un alejamiento crítico de la tradición del tradicionalismo. Cristóbal Torres (1994) afirma acerca las tradición sociologíca "bajo ese rótulo, con lo que ello significa de estructurar de forma permanente un determinado campo de problemas" 
Además de sus intentos de comprender el concepto de tradición con cuatro tipos básicos de acción social, Weber formula una teoría del gobierno político, distinguiendo entre el gobierno carismático, el racional, el legal y el tradicional. En esta teoría se estableció el concepto de tradición estrechamente a un individuo dominante. La característica principal de esta regla basada en la tradición es que el orden político se basa principalmente en el conocimiento tradicional, en la obediencia personal y, a diferencia de la regla carismática, tiene un carácter cotidiano. (Ursprung, 2007 p. 27)

Sin embargo, la comprensión de la tradición por parte de Max Weber solo tiene un valor limitado para describir adecuadamente el fenómeno de la transmisión intergeneracional y la influencia en la formación de grupos sociales. La yuxtaposición de tradición pre-racional y modernidad racional no funciona, el proceso de modernización erosionaría gradualmente. El proceso de modernización ofrece una imagen diferenciada: algunas tradiciones son reemplazadas por desarrollos y percepciones modernas, llamadas también demolición tradicional, algo de modernidad y tradición en un conflicto insuperable, llamado tradicionalismo; en parte, la tradición y la modernidad coexisten sin conflicto e incluso de complementan, como es el caso de la medicina alternativa. La función social de la tradición en las sociedades modernas y posmodernas es organizar la memoria colectiva de una sociedad (Giddens, 1993). Para el análisis sociológico del fenómeno de la tradición hay tres aspectos según el sociólogo Edward Shils: formal, por contenido y estructuralmente. Desde un punto de vista formal. La tradición depende del proceso de la misma. El contenido que pasó o no se transmite puede ser de interés cultural e histórico, pero sociológicamente no es interesante para ser considerada una tradición. En términos de contenido, las tradiciones se caracterizan por una apreciación especial o un reclamo especial basado en la orientación al pasado. Estructuralmente la tradición se basa en la repetición, transmisión y ritualización. En la perspectiva de estos tres aspectos, se puede observar cómo los patrones de orientación cultural de la tradición, la tradición y el pasado se adentran en el presente y lo influye. (Shils, 1991, p. 32)

Siguiendo el ejemplo de Shils, el psicólogo organizacional estadounidense Karl E. Weick define la tradición como algo que se ha generado, llevado o creído en 
el pasado, o que se cree que ha existido, ejecutado o creído en el pasado, y el de uno. Shils y Weick coinciden además: "Para calificar como una tradicón, una acción debe entregarse al menos dos veces en tres generaciones" (Weick, 1995, p. 124)

\section{ii. Tradición en la etnología}

La antropología formó su propio debate sobre el tema en 1982 en la que la tradición se caracteriza por la comprensión de la tradición como una construcción cultural. A principios de la década de 1980, el punto de partida de estos principios fue en el trabajo del historiador Eric Hobsbawm y del antropólogo Roger Keesing. La tesis "La tradición inventada", publicada en 1983, de los dos historiadores sociales Eric Hobsbawm y Terence Osborn Ranger, critica que muchas tradiciones son atribuidas a un fondo antiguo las cuales son comparativamente joven, como lo ejemplifican las culturas escocesas y galesas, cuyas raíces se encuentran en el siglo XIX. El ejemplo más conocido es la llamada tradición del típico escocés con falda escocesa y gaita, la cual se presentó como vestimenta de protesta solo después de la unión con Inglaterra, pero se considera como tradición original de Escocia. (Hobsbawm y Keesing, 1983, p.15). Un año antes, Roger Keesing y Robert Tonkinson tuvieron en su ensayo reinventar la cultura tradicional sobre la base de la investigación etnológica en Melanesia. El término kastom (una palabra de Pijin derivada de la costumbre inglesa, traducible como "tradición") intenta mostrar que la autoimagen cultural está fuertemente influenciada por influencias coloniales y difiere significativamente de las costumbres pre-coloniales. En 1984, Jocelyn Linnekin y Richard Handler entendieron la tradición como construcción y representación simbólica. (Linnekin y Handler, 1984). Estos antropólogos demarcaron el uso analítico de la palabra de la comprensión cotidiana, según la cual la tradición parece ser algo que puede transmitirse. Por otro lado, enfatizaron que las tradiciones, como construcciones simbólicas de la generación actual, las cuales siempre son interpretaciones y podrían ser cambiadas dependiendo de la comprensión dada. Esto da lugar a lo que Linnekin y Handler Ilaman "la paradoja de la tradición", lo cual afirma que tratar de preservar auténticamente una tradición requiere una interpretación de esa tradición, y eso es precisamente lo que la cambia. El fin de esta construcción 
simbólica se basa en usar el material del pasado para comprender las acciones, el comportamiento y las relaciones en el presente.

\section{iii. Tradición en la historia}

En la ciencia histórica, se entiende por "tradición" la transmisión oral o escrita de información con el fin de preservarla para la posteridad. El término se usa para distinguir la tradición como una tradición consciente del remitente. El concepto de "tradición inventada" introducido en la historia social toma en consideración la perspectiva inversa de la construcción tradicional, consciente o inconsciente, de la posteridad en oposición al par de conceptos "tradición remanente" y enfatiza la construcción social de la historiografía en sí. (Hobsbawm y Keesing, 1983, p. 18).

\section{iv. Tradición en la jurisprudencia}

En el antiguo lenguaje legal (la ley romana), la tradición era el acto de transferencia de una cosa móvil, por ejemplo, la herencia y la compra. Por lo tanto, todavía se emplea el uso de la tradición al momento de efectuarse la entrega. En la jurisprudencia moderna, la teoría de la tradición se refiere a un enfoque particular de la demarcación del derecho público desde el derecho privado. La teoría de la tradición se refiere a la opinión de que ciertas áreas del derecho se asignan tradicionalmente al derecho público. Estos incluyen, por ejemplo, litigios dentro de la ley policial, regulatoria y administrativa.

Además de la teoría de la tradición, existen otras teorías de demarcación de interés, la teoría de la subordinación y la teoría de la tradición. En el campo de las ciencias auxiliares históricas, un uso cercano al significado jurisprudencial es común, si las transferencias de bienes inmuebles a los monasterios y su certificación se llaman tradición. (Weick, 1995)

\section{v. Tradición en la filosofía}

En filosofía, el concepto de tradición difícilmente juega un papel. Incluso en los manuales establecidos hay una falta de discusión sobre el tema y un análisis del término. El filósofo Karl Popper vio el desarrollo de una teoría de la tradición 
sobre todo como una tarea de la sociología, no de la filosofía. (1945) En este sentido, usualmente se utilizan definiciones sociológicas o socio-antropológicas. Filósofos como Josef Pieper, junto a su colega Alasdair Maclntyre, han sido de los pocos filósofos preocupados por la teoría de la tradición. Por encima de todo, Pieper se centró en la conexión entre la filosofía medieval y el catolicismo. En su obra Formas básicas de las normas sociales (1933) discutió la tradición principalmente debido a la incorporación histórica de toda la vida cultural. MacIntyre, como colaborador de Pieper, ha señalado la necesidad de estándares tradicionales y regionales para la ética y la política contemporáneas. En contraste con Pieper y MacIntyre y en particular con la teoría del discurso de Jürgen Habermas, Karsten Dittmann ha intentado recientemente entender la tradición como una condición de discursos intergeneracionales e ilimitados que hacen comprensibles los procesos de cambio de larga duración, como el proyecto de la llustración. (Dirrmann, 2004.)

\section{c. Tradiciones culturales}

Una tradición cultural es el cuerpo expresivo de la cultura compartida por un grupo particular de personas. Esta abarca las tradiciones comunes a esa cultura, subcultura o grupo. Incluyen tradiciones orales como cuentos, proverbios y chistes. Así mismo la cultura material, la cual abarca desde estilos de construcción tradicionales hasta juguetes hechos a mano. Una tradición cultural también incluye formas y rituales de celebraciones como la Navidad y las bodas, danzas populares o ritos de iniciación. Cada uno de estos, ya sea individualmente o en conjunto, se consideran parte de tradición cultural. Tan esencial como la forma, las tradiciones culturales también abarcan la transmisión de estos elementos de una región a otra o de una generación a otra. Estas tradiciones se transmiten informalmente de un individuo a otro, ya sea a través de instrucciones verbales o demostraciones.

La transmisión es una parte vital del proceso de tradición cultural. Sin comunicar estas creencias y costumbres dentro del grupo a través del espacio y el tiempo, se convertirían en fragmentos culturales relegados a los arqueólogos culturales. Las tradiciones culturales continúan transmitiéndose informalmente, como una regla anónima y siempre en múltiples variantes, está basado en la comunidad y 
nutre su conocimiento en la comunidad. "A medida que surgen nuevos grupos sociales, se crean nuevas tradiciones culturales como surfistas, motociclistas, programadores de computadoras". (Dundes, 1980, p. 7). En contraste directo con las bellas artes, donde cualquier obra de un artista nombrado está protegida por la ley de derechos de autor, las tradiciones culturales son una función de identidad compartida dentro de cada grupo social.

Habiendo identificado elementos populares, la comunidad se esfuerza por comprender el significado de estas creencias, costumbres y objetos. Estos elementos culturales no se transmitirían a menos que tuvieran alguna relevancia continua dentro del grupo (Dundes, 1980, p. 5). Sin embargo, ese significado puede cambiar y transformarse. Por ejemplo, el Mikve es hasta ahora un ritual de limpieza del judaísmo ortodoxo que significaba originalmente buena salud pública en una tierra con poca agua; sin embargo en nuestros días esta costumbre significa la importancia de ser considerado un judío ortodoxo. Así mismo el cepillado de los dientes, también transmitido dentro de un grupo, sigue siendo un problema práctico de higiene y salud y no se eleva al nivel de una tradición que define a determinado grupo. (Dundes, 1980, p. 1). Una vez que la tradición cultural pierde su propósito práctico, no hay razón para una transmisión a menos que haya sido atribuido un significado más allá de la practicidad inicial de la acción, este significado se encuentra en el núcleo de la tradición cultural. Con una sofisticación cada vez más teórica de las ciencias sociales, se ha hecho evidente que las tradiciones culturales son un componente natural y necesario de cualquier grupo social, de hecho es todo a nuestro alrededor. (Sims \& Stephens, 2005). Una tradición cultural no tiene que ser vieja ni anticuada, esta se sigue creando, transmitiendo y en cualquier grupo se utiliza para diferenciar entre "nosotros" y "ellos".

Los elementos individuales de las tradiciones culturales se clasifican comúnmente en tres tipos: material, verbal o tradicional. En su mayor parte, estas categorías incluyen objetos físicos (cultura material), dichos, frases, refranes, expresiones, historias y cantos (tradición cultural verbal) y creencias y formas de hacer las cosas (tradición cultural de costumbres). También hay un cuarto subgénero importante enfocado a los juegos de los niños, ya que la recopilación e interpretación de este tema fértil es peculiar de los patios escolares y en los 
barrios. (Opie \& Opie, 1969). Cada uno de estos géneros y sus subgéneros están destinados a organizar y categorizar los elementos de una tradición cultural; proporcionando un vocabulario común y un etiquetado consistente para que su difusión sea ligera y provechosa.

\section{i. Tradición cultural verbal}

La definición formal de tradición verbal son palabras, tanto escritas como orales, que son "formas habladas, cantadas y expresadas de expresiones tradicionales que muestran patrones repetitivos". (Dorson, 1972, p. 2). La información verbal no es una conversación cualquiera, sino palabras y frases que se ajustan a una configuración tradicional reconocida tanto por el orador como por el público. Por definición, los tipos narrativos tienen una estructura coherente y siguen un modelo existente en su forma narrativa. Como un simple ejemplo, en la frase "Se juntan un peruano, un chileno y un argentino..." marca instantáneamente el siguiente texto como una broma. Esto es tradición cultural en acción. Otro ejemplo es la canción infantil "En la granja de mi tío ia-ia-oh", donde cada actuación es distintiva en los animales nombrados, su orden y sus sonidos. Canciones como esta se usan para expresar valores culturales, las granjas son importantes y enseñan a los niños sobre diferentes animales domesticados. (Sims \& Stephens 2005, p. 13). Esto es tradición cultural en acción.

En 1846 William Thoms, escritor británico que acuñó el término folclore, realizó un pedido de ayuda dirigido a los estudiosos de todo el continente europeo con el fin de documentar elementos de la tradición verbal. A principios del siglo XX, estas colecciones habían crecido para incluir elementos de todo el mundo y a lo largo de varios siglos. Fue tan grande el acojo que se hizo necesario un sistema para organizarlos y clasificarlos. (Georges \& Jones, 1995, pp. 112-13). Antti Aarne publicó un primer sistema de clasificación para cuentos populares en 1910. Más tarde, Stith Thompson lo amplió al sistema de clasificación "AarneThompson" y sigue siendo el sistema de clasificación estándar para cuentos populares europeos y otros tipos de literatura oral. A medida que crecía el número de elementos orales clasificados, se observaron similitudes en elementos que se habían recopilado de regiones geográficas, grupos étnicos y épocas muy diferentes, dando lugar al Método Histórico-Geográfico, una 
metodología que dominó la tradición cultural en la primera mitad del siglo XX. Cuando William Thoms publicó por primera vez su llamamiento para documentar la tradición verbal de las poblaciones rurales, se creía que estos elementos populares se extinguirían a medida que la población adquiriera alfabetización. Durante los últimos dos siglos, esta creencia ha demostrado ser errónea; los folkloristas continúan recopilando información verbal, tanto escrita como hablada, de todos los grupos sociales. Algunas variantes podrían haberse conseguido de colecciones publicadas, pero gran parte de ellas aún se transmiten oralmente $y$, de hecho, continúan generándose en nuevas formas y variantes a gran velocidad.

\section{ii. Cultura material}

El género de la cultura material incluye todos los elementos que se pueden tocar, sostener, vivir o comer. Son objetos tangibles, con una presencia física prevista para su uso de forma permanente o no. La mayoría de estos elementos de tradición cultural son objetos individuales que se han creado artesanalmente para un propósito específico. Sin embargo, los elementos populares también pueden producirse en masa, como los dreideles (juguete judío) o las decoraciones navideñas. Estos artículos continúan siendo considerados tradición cultural debido a su larga historia (preindustrial) y su uso habitual. Todos estos objetos materiales "existían antes y continúan junto con la industria mecanizada (...) Se transmiten a través de las generaciones y están sujetos a las mismas fuerzas de tradición conservadora y variación individual que se encuentran en todos los elementos populares" (Dorson, 1972, p. 2). Estos elementos son de interés por su forma física, su método de fabricación o construcción, su forma de uso y la obtención de las materias primas y el significado para aquellos que hacen y usan estos objetos. Es también de importancia primordial el complejo equilibrio de continuidad sobre cambio tanto en su diseño como en su decoración. Por ejemplo, en Europa, antes de la Revolución Industrial, todo se hacía a mano. Mientras que algunos pobladores del siglo XIX querían asegurar las tradiciones orales de la gente rural antes de que la población aprendiera a leer y escribir, otros artesanos trataron de priorizar objetos hechos a mano antes de que sus procesos de producción se perdieran en la manufactura industrial. Así como la tradición verbal continúa siendo activamente creada y transmitida en la cultura actual, también estas artesanías, 
posiblemente con un cambio de propósito y significado, todavía se pueden encontrar a nuestro alrededor. Los objetos hechos a mano han adquirido prestigio ya que se invierte tiempo y esfuerzo en su creación y se valora su singularidad. (Roberts, 1972, p. 236). Para los artesanos, estos objetos hechos a mano incorporan relaciones multifacéticas entre ellos mismos y los usuarios, la cual carece completamente de artículos producidos en masa sin conexión con un artesano individual. (Schiffer, 2000). Independientemente de la motivación para la artesanía, este acto se considera tradición cultural en acción. Muchas artesanías tradicionales se han catalogado como artes finas o aplicadas y se enseñan en escuelas de arte, como la ferretería y la fabricación de vidrio. (Roberts, 1972, p. 240). O se reutilizan como arte popular, caracterizados como objetos en los que la forma decorativa supera sus necesidades utilitarias. El arte popular se encuentra en esculturas de hombre de hojalata hechas por trabajadores metalúrgicos, exhibiciones navideñas en el patio de una casa, dibujos en la última página del cuaderno de cualquier estudiante, tatuajes, etc. "Palabras como ingenuo, autodidacta e individualista se utilizan para describir estos objetos, y se presenta la creación más excepcional que representativa". (Dorson, 1972, p. 4). Sin embargo, este tipo manifestación cultural contrasta con la comprensión de elementos referidos a las tradiciones culturales que se nutren y transmiten en comunidad. Muchos de estos objetos materiales, así sean grandes o pequeños, son difíciles de clasificar, difíciles de archivar y difíciles de almacenar. La labor de preservar este tipo de elementos muchas veces voluminosos de la cultura material es una tarea asignada a los museos.

\section{d. Importancia de las tradiciones culturales}

Las tradiciones culturales juegan un papel muy importante en la identificación, definición, prevención y determinación del comportamiento humano (Pomianek, 2011). Estas son importantes porque transmiten valores, historias y objetivos compartidos de una generación a otra. Las tradiciones alientan a los grupos de personas a crear y compartir una identidad colectiva, que a su vez sirve para dar forma a las identidades individuales. Estas son expresiones de la cosmovisión de un grupo en particular y ayudan a las personas en ese grupo a marcar ocasiones significativas o transiciones de la vida. "A medida que el niño crece, 
se desarrolla un sentido de pertenencia no sólo a la familia, sino a la comunidad, la nación y un grupo cultural". (Hagerty, 1992).

Las tradiciones culturales se consideran importantes al ser conocimiento vivo y existente. Son conocimientos arraigados en la mente del hombre que han perdurado con el pasar de los años. Una tradición cultural promueve y difunde valores compartidos, historias, acciones que traspasan generaciones. La sociedad se ve motivada a participar en una identidad colectiva, que simultáneamente da vida a identidades culturales individuales. La identidad cultural "emerge y se reafirma en la medida en que se confronta con otras identidades, en el proceso de interacción social” (Giménez, 1996)

Cada ser humano pertenece a una cultura diferente, y esta delimita nuestra percepción de nosotros mismos como individuos y de nuestro entorno, a su vez es un nexo entre nuestros ancestros y tradiciones culturales. Cada ser humano tiene por necesidad identificarse con un grupo de personas, ese instinto de pertenencia es manifestado gracias al aprendizaje y al efecto de inculcar una herencia étnica, religiosa y cultural. Maslow (1954)

La llegada de la era digital acarrea un cuestionamiento que se enfoca en la relevancia de las tradiciones culturales en este nuevo siglo. Por ejemplo, Lima es conocida como una ciudad de inmigrantes, todos vinieron originalmente de algún otro lugar, ya sea nacional o internacional. Las tradiciones culturales que se ven surgen de patrones culturales que subyacen a los diferentes grupos étnicos. El lenguaje y las costumbres proporcionan una ventana a su visión de la realidad. "El estudio de diferentes visiones del mundo entre grupos étnicos en Lima sigue siendo una de las tareas pendientes más importantes para los antropólogos" (Degrégori \& Portocarrero, 2005)

Contrariamente a una preocupación generalizada, se puede percibir una pérdida de diversidad y una creciente homogeneización cultural en toda la tierra. Los críticos de esta teoría señalan que a medida que se mezclan diferentes culturas, el paisaje cultural se vuelve multifacético con la mezcla de aduana. Los limeños se dan cuenta de otras culturas eligen diferentes elementos para adoptar unos de otros.

\section{e. Tradiciones en el Perú}




\section{i. Tradiciones festivas}

En el Perú se celebran cada año alrededor de 3000 fiestas tradicionales, típicas de cada región del país. (PromPerú, 2012). La mayoría es para conmemorar el día de un santo patrono. Aquellos santos originalmente formaban parte del calendario cristiano en el período colonial, sin embargo estas celebraciones se mezclaban con la religión de regiones andinas. Un ejemplo de este sincretismo cultural es la Fiesta del Corpus Christi en Cusco. Este día religioso, originalmente introducido por los españoles, fue aceptado por los habitantes cusqueños incorporando a la celebración rituales de procedencia incaica Estas festividades se realizan en costa, sierra y selva y generalmente están relacionados con santos patronos, mitos antiguos o fechas importantes para la agricultura.

El 24 de junio de cada año se celebra el Inti Raymi, que en quechua significa "Fiesta del Sol". Es un festival religioso Inca en honor al Inti, el dios sol. Esta celebración marca el solsticio de invierno en el hemisferio sur de los Andes y se sigue celebrando simbólicamente en la fortaleza de Sacsayhuamán, a dos kilómetros de la ciudad del Cusco. Durante la época de los incas, el Inti Raymi era el más importante de los cuatro festivales celebrados en el Cusco, de acuerdo a informes del Inca Garcilaso de la Vega (1609), y marcaba el comienzo del año. Las celebraciones duraban 9 días en el que se realizaban bailes y sacrificios. El último Inti Raymi con la presencia del emperador Inca, se llevó a cabo en 1535. (Garcilaso de la Vega, 1609). Esta celebración fue prohibida en 1572 por el virrey Francisco de Toledo, al considerarlo un acto pagano, a partir de entonces se celebraba de manera clandestina. No fue hasta 1944 que el Inti Raymi volvió a renacer gracias a la reconstrucción histórica que realizó Faustino Espinoza Navarro, el cual en 1953 fundó la Academia de la Lengua Quechua. La reconstrucción se basa en la crónica del Inca Garcilaso de la Vega y sólo se refiere a la ceremonia religiosa. Desde esa fecha, la ceremonia ha vuelto a un evento público y una importante atracción turística. Hoy en día, el Inti Raymi es un espectáculo que despierta la conciencia nativa de los cusqueños, los cuales participan masivamente con entusiasmo. La representación, que reúne a miles de personas, comienza delante del Coricancha, donde el "Inca" realiza una invocación al sol. Los espectadores, sin embargo, esperan en la explanada de Sacsayhuaman, hasta que se presente la procesión. Es ahí donde se realiza el 
sacrificio a una alpaca, seguido de danzas típicas de la región. Con casi sesenta años de existencia, el nuevo Inti Raymi es ahora parte inseparable de la vida de Cusco.

Otra celebración importante es la del Corpus Christi, la cual se celebra en la mayoría de los departamentos del Perú, siendo el de Cusco una de las más impresionantes. Quince santos y vírgenes, organizados en varias procesiones, llegan a la catedral del Cusco a saludar al cuerpo de Cristo. Este acontecimiento se celebra 60 días después del domingo de Pascua. Durante el día se escucha la María Angola, la mayor campana de Iglesia del Perú, construida durante el siglo XVI por Diego Arias de la Cerda. Platos típicos como el olluquito con charqui lawa de chuño, pepián de cuy, acompañados con chicha de jora, adornan las mesas familiares durante las celebraciones. El día principal del Corpus Christi, alrededor del mediodía, se realiza la tradicional procesión, en donde la plaza de armas se llena de gente para ver a los santos. Después de la procesión, los santos regresan a la catedral y los representantes de las comunidades locales se reúnen, discutiendo problemas locales. Pasado los siete días, los santos participan en la procesión nuevamente, antes de volver a los lugares donde permanecerán por el resto del año. El Corpus Christi es una ceremonia muy colorida y tradicional en el Perú.

En Lima, una de las celebraciones más importantes es la del Señor de los Milagros, festival católico que se celebra en Octubre de todos los años. El origen se remonta al retrato de un Cristo negro crucificado, que se encontró en 1651 en una pared de barro en el barrio de Pachacamilla. El cuadro probablemente fue pintado por un esclavo negro originario de Angola, que habría emigrado con los españoles en el curso de la conquista del Imperio Inca. Según la leyenda, esta imagen en la pared resistió todos los intentos de removerla, sobreviviendo incluso al terremoto del 13 de noviembre de 1655, que destruyó casi toda la ciudad de Lima. (RPP Noticias, 2017). A continuación, la pared con la imagen se convirtió en un lugar de peregrinación para la comunidad afroperuana. El 20 de octubre de 1687, casi 32 años después, aconteció otro terremoto mucho más fuerte en la capital del Perú, Para sorpresa de muchos el muro de la imagen seguía intacto, es ahí donde todos los sectores de la población se unieron, hasta el día de hoy, rindiéndole culto. La procesión del Señor de los Milagros es una 
de las procesiones más importantes de Lima. En un anda de caoba de 2000 kilos lleva una imagen pintada al óleo del Cristo Moreno, es cargado sobre los hombros de 40 portadores de la Hermandad del Señor de los Milagros alternando cada 15 minutos. La procesión comienza en la iglesia de Las Nazarenas y termina en la iglesia de La Merced. El anda cruza el Centro de Lima, cubriendo una distancia de casi seis kilómetros. Detrás de la imagen, 75 sahumadoras entonan himnos tradicionales, posteriormente les siguen orquestas de música y por último, les sigue la población de Lima, conectándose con la procesión. Las personas pertenecientes a la hermandad, los fieles y sobre todo las mujeres visten de morado durante el mes de octubre. Este color se atribuye la fundadora del Instituto Nazareno, Antonia Lucía del Espíritu Santo, quien fue responsable de la elección de la ropa en el año 1677.

\section{ii. Tradiciones culinarias}

La cocina peruana es muy variada y el resultado de la fusión inicial de la tradición del antiguo Perú con la cocina española en su variante influenciada por la presencia de los moros en la Península lbérica e importante contribución de las costumbres culinarias traídas de la costa atlántica de África subsahariana por esclavos. (Rodríguez, 2007). A partir de entonces, este mestizaje se vio influenciado por el uso y costumbres culinarias de chefs franceses que huyeron de la revolución en su país para instalarse en la capital del Perú. Así mismo la influencia de la inmigración del siglo XIX, que incluyó chinos, japoneses e italianos, entre otros países de Europa. (Editores SD Portal UMAMI, 2017). Como particularidad exclusiva de la gastronomía del Perú, existen comidas y sabores de cuatro continentes en un solo país. El arte culinario peruano está en constante evolución y, sumada a la variedad de platos tradicionales, hace imposible establecer una lista completa de sus platos representativos. Una amplia variedad de comida peruana se basa en tres fuentes: la particularidad de la geografía del Perú, la mezcla de sus culturas y la adopción a la cocina moderna.

La presencia de diferentes niveles de altitud en los Andes del Perú permite una serie de microclimas y especies, desde regiones cubiertas de nieve hasta selvas tropicales, con 84 de las 104 zonas climáticas existentes en el planeta, es uno de los 12 países del mundo poseedores de una mega diversidad ambiental. Perú tiene condiciones adecuadas para el cultivo de frutas y verduras durante todo el 
año. Además, el agua de la corriente de Humboldt permite una amplia variedad de pescados y mariscos.

Desde la época pre colombina los Andes centrales peruanos fueron el más grande centro de domesticación de plantas del mundo antiguo, con especies nativas tales como el maíz, tubérculos con dos mil variedades de papas, camotes, yucas, maca, hierbas, quinua, kiwicha; frutas como la chirimoya, la lúcuma, el pacay, el tomate, la calabaza, la palta, sauco; legumbres, como frijoles, habas, maní y una multitud de hierbas aromáticas. Productos nativos que se siguen consumiendo hasta el día de hoy en diversas partes del mundo.

Antes de la llegada de los europeos, la geografía peruana cubría una amplia variedad de culturas, conquistado por el Imperio Inca, cada una poseía características gastronómicas particulares, aunque presentaban generalidades, según los cronistas de la época. Por ejemplo, los principales condimentos eran hierbas, yuyos, sal y especialmente el pimiento, llamado uchu en tiempos incas y ahora considerado un elemento clave de la cocina peruana. (Azcoytia, 2008) La preparación de alimentos se realizaba en forma deshidratada para impedir su descomposición, destacando la carne seca. Los antiguos peruanos, además, consumían grandes cantidades de peces y mariscos. También suplementaban su dieta con carne de pato, cuyes y camélidos domésticos, como llamas y alpacas. En las sociedades de la costa norte se consumía ciertos lagartos y ciervos. En las regiones de la Amazonía peruana se solía consumir una amplia variedad de especies de la flora y fauna de la selva. Desde tiempos antiguos los antiguos peruanos preparaban guisos y sopas. Por ejemplo, la carapulcra se considera el estofado más antiguo de la historia peruana. (Rodríguez, 2007)

Desde el inicio de la presencia española, se incorporaron nuevos usos y costumbres culinarias con el inicio Virreinato del Perú. Freír, el uso de productos lácteos, así como consumir carne de res, cerdo, huevos de pollo, aves de corral, etc. También sembraron cultivos que resultan hoy en día esenciales para la nueva cocina como la cebolla y el ajo, que combinados con la pimienta, son los principales ingredientes de muchos platos peruanos.

El material culinario traído por los españoles se adaptó con el tiempo a la tierra peruana. El conquistador español Francisco Pizarro, el cual crió cerdos en su 
infancia, era el aficionado principal al plato llamado chicharrón, platillo que se sigue disfrutando hasta el día de hoy. La dedicación de muchos conventos de monjas a la cocina en proximidades donde abundaba la plantación de azúcar (especies traídas por los españoles) y la enorme variedad de frutas nativas originó, además, una larga tradición de postres y decenas de dulces, destacando el alfajor. Los esclavos africanos contribuyeron a la gastronomía de la época con varios guisos, además de la utilización de trozos de carne que eran las sobras de los patrones. También implementaron la cocina en brasas. Gracias a estas prácticas la gastronomía del Perú posee una gran variedad de platos representativos de la corriente de comida criolla, por ejemplo: los anticuchos, la sangrecita, la papa rellena, el cau cau, la pancita, las mollejitas, la chanfainita, el choncholí y el tacu tacu.

Después de la independencia se dieron una serie de migraciones de diversas procedencias que integraron sus propias tradiciones a la dinámica culinaria local. La migración de los chinos cantoneses a mediados de siglo XIX popularizó el salteado de alimentos, sabores agridulces en la carne y el uso de nuevas hierbas y salsa de soja. Sin embargo su contribución más notable fue el arroz, aunque ya consumido desde el siglo XVI, es gracias a la inmigración china que el arroz se hizo popular y se convirtió en la guarnición peruana por excelencia, a expensas de pan. La forma preferida de arroz en el Perú es el arroz granulado, no demasiado cocido, sin embargo la preparación china dio instancia al uso de ajo y sal. Otra inmigración en la segunda mitad del siglo XIX fue la italiana, que popularizó el uso de masas, pasteles, postres, como el panettone (panetón), elemento obligatorio en el Perú en todas las navidades. Por último, la inmigración japonesa a finales del siglo XIX impactó la cocina marina peruana. Cortes y técnicas japonesas muy prolijas, unidas a las salsas y preparaciones peruanas dieron vida a una nueva vertiente culinaria en el Perú. Gracias a esta influencia japonesa, el Perú tiene platos como el popular ceviche, lomo saltado, entre otros. (Rodríguez, 2007).

En la última década del siglo $X X$ y a comienzos del siglo XXI la cocina peruana comenzó a popularizarse en el extranjero, siendo reconocido en el 2012 como un destino culinario importante en todo el mundo. La gastronomía del Perú está registrada como marca mundial a través de platos y productos que llevan la 
bandera del Perú. Debido a esta variedad y la armonía del gusto, la cocina peruana es constantemente premiada internacionalmente y sus cocineros a menudo hacen distinciones y premios internacionales. Un elemento destacado es su constante apertura a las innovaciones y el continuo desarrollo de nuevos platos, incorporando a la gastronomía la búsqueda continua de la experimentación y vanguardia.

Así como cada región conserva su riqueza culinaria, la alta gastronomía destaca la mezcla de colores y productos alimenticios. Un ejemplo de esto es la cocina novoandinos, un nuevo estilo culinario surgido en el Perú nacido del interés de los gastrónomos locales para reanudar las costumbres alimentarias del pasado prehispánico: recreándolas, rescatando y revalorizando la cultura del Perú. En esta recreación de la cocina andina, entran elementos procedentes de otros horizontes culturales. Algunos de los productos utilizados son nativos tarwi, chuño, quinua, amaranto, cochayuyu, maca, coca, uchu, olluco y papas. Lima, la capital y Arequipa han convertido en la sede principal de esta cocina actual, aunque principales puntos andinos como Huaraz, Juliaca, Cusco y Huancayo vienen siguiendo sus pasos.

\section{iii. Tradiciones artesanales}

Las tradiciones artesanales en el Perú es una categoría bien diversificada. Son producto de la influencia de una multitud de culturas antiguas que habitaban su territorio actual. Esta actividad también representa una importante fuente de ingresos para su población, que incluso se dedica a la exportación de gran parte de su producción. Los materiales utilizados en la confección la artesanía peruana son diversos: madera, piedra, oro, plata, cerámica, cuero, bambú, fibras vegetales y una serie de lanas, de oveja y de los famosos camélidos sudamericanos como la llama, la alpaca y la vicuña. De estas últimas se producen blusas y abrigos, así como los peculiares "chullos": gorros que protegen las orejas y que generalmente son bastante coloridos. Así mismo, como parte de la artesanía también se destacan los instrumentos musicales, como el charango y una infinidad de instrumentos de soplo como zampoñas, quenas, sicus, antaras, pututus, etc.

\section{B. Juegos infantiles}




\section{a. Tradicionales}

Los juegos infantiles son una manera de conocer y ponerse en contacto con el niño y por lo tanto forman parte de una herramienta esencial para su comprensión. Teniendo en cuenta las necesidades de conocer e integrar el mundo, existen diferentes juegos infantiles dependiendo de la edad del infante. El juego es un signo de la personalidad del niño, a través de las experiencias y sentimientos y la simbología del mismo juego. Además, los niños transforman en su imaginación juegos simbólicos, como simplemente jugar con muñecas, siendo muy significativo en su cultura. Por ejemplo, en algunas sociedades, los juegos cooperativos fomentan el trabajo en grupo; en otros, ganar el juego tiene mucha importancia y es vista desde una perspectiva individualista y competitiva. (George, 2004, p. 11). En el juego, las diferencias entre niñas y niños también son considerables: mientras que los juegos para niños son más físicos, las niñas juegan juegos más simbólicos. (George, 2004, p. 15). El juguete físico constituye la importancia y utilidad de jugar, ya sea una figura de acción, una pelota o una cuerda, este se considera necesario como objeto de transición. Jean Piaget ha sido una de las principales figuras en el campo de los juegos para niños, diferenciando las etapas de estas. María Montessori y otros educadores enfatizan la importancia de los juegos para el desarrollo infantil. El juego infantil es una actividad mundial, la cual fue, es y seguirá siendo desarrollada en los 5 continentes y en la historia universal. Los juegos infantiles presentan similitud en todo el mundo, adaptándose a las peculiaridades de cada país.

Conscientes de la importancia de los juegos infantiles, La Asamblea General de Naciones Unidas en el año 1989, publicó en la Convención del Niño acerca de los derechos de los niños a jugar y recrearse: teniendo derecho al descanso, ocio, recreación dependiendo de su edad y cultura. Así mismo el derecho de participar libremente en todo tipo de actividades recreacionales. (Asamblea General de Naciones Unidas, 1989). La sociedad globalizada del siglo XXI, influenciada por la era tecnológica, pone en riesgo a los juegos infantiles, ya que prioriza los juegos electrónicos, los celulares, y la televisión en vez que los juegos convencionales y de antaño.

\section{i. Teoría del juego infantil}


La primera referencia teórica enfocada a los juegos para niños fue la ley del filósofo Platón, la cual hablaba sobre los juguetes, su representación e influencia cuando los niños pasaban a ser adultos. Aristóteles también abogó por que los juegos infantiles ayuden a entrenar a los adultos. No fue hasta el siglo XIX, en donde el juego se convirtió en un centro de investigación pedagógica para incorporarlo en estructuras socioeconómicas. Recién desde esa época se comenzó a usar el juego para enseñar materias escolares, preparando al niño a la sociedad. Esta tendencia se desarrolló en Alemania, en donde Johann Bernhard Basedow, de la mano de John Locke y Jean-Jacques Rousseau, llegaron a la conclusión que es de vital importancia desarrollar el aprendizaje a través del juego, sin forzar a los niños (Wright, 1789). Estos pensadores entendieron el valor de la educación de un niño de manera óptima, sin embargo paradójicamente no lograron desarrollar sus teorías en las escuelas que ellos mismos crearon (Elschenbroich, 1979). En ese mismo siglo se crearon las primeras teorías sobre el juego infantil. Friedrich Fröbel, fundador del primer jardín de infancia y pedagogo, y Johann Heinrich Pestalozzi, trataron de hacer del juego una herramienta educativa, inventando juegos que fueran ideales para la escuela, incluyendo piezas de madera y escribiendo libros sobre el tema. Estos pedagogos también defendieron el valor de los juegos educativos. Sus ideas no se difundieron y sus opiniones sobre los juegos infantiles se perdieron a lo largo del tiempo. (Elschenbroich, 1979). A finales del siglo XX, Friedrich Schiller confirmó que desempeña el papel del filósofo para disipar el excedente de energía, basado en el juego animal: satisfaciendo la necesidad. Paulatinamente estas ideas comenzaron a tomar forma hasta coincidir con la teoría evolutiva del naturalista Charles Darwin. El psicoanálisis enfatizó la importancia de los juegos en el desarrollo emocional del niño. En este sentido, la psicóloga Melanie Klein, en su libro “El psicoanális de los niños" (1932) propuso el juego como una psicoterapia para los niños. Al mismo tiempo, basándose en las interpretaciones psicoanalíticas del juego, se expandieron nuevas experiencias directamente en la escuela, como la Escuela Summerhill, la cual promovió el juego completamente gratuito. Por otro lado, Jean Piaget y Lev Vygotsky. Destacan la importancia cognitiva del juego en sus teorías de las etapas cognitiva de la infancia. Piaget explora la función de socializar y expresar 
la realidad de una manera simbólica y Vygotsky confirmó la autorregulación de los juegos (Sawyer, 2010)

\section{ii. Importancia del juego infantil}

El desarrollo físico y emocional de un niño se debe en gran parte a los años que ha jugado durante su infancia.

Los beneficios de los juegos incluyen:

- Como psicomotor, desarrolla el cuerpo y los sentidos, controlando la motricidad y el equilibrio, experimentando con nuevas sensaciones y ofreciendo un funcionamiento completa del cuerpo.

- Desde el punto de vista de la inteligencia, el juego exige razonamiento y creatividad para los niños.

- En términos de socialización, abre las posibilidades de contactar con otros niños. Al igual que los adultos, los niños crean asociaciones infantiles que repiten normas y comportamientos sociales en los juegos infantiles; El juego da vida, placer y disfrute, y por lo tanto su desarrollo emocional esencial.

El psicólogo Jean Piaget ha separado tres edades referidos a los juegos infantiles. En los dos primeros años de la vida de un niño, el juego es un motivo sensorial, es decir, sus movimientos y actividades están relacionadas con sus sentidos, y es capaz de recrear estas actividades y repetirlas con placer. Dentro de este período, existen varios períodos: hasta los 6 meses, el niño juega con la boca, los dedos, las manos y los pies, tocando y chupando los objetos. Cuando aprende a sentarse, el niño juega con propiedades de rastreo. Cuando camina, juega arrastrando cosas. Con mayor destreza, manipula objetos con un período de 15 a 18 meses: tiene la facultad de abrir cajas o colocar objetos uno encima del otro. (Gaztelaniaz, 1990).

En el segundo período, entre los 2 y 6 años de edad, se desarrollan juegos simbólicos. El infante transforma la realidad, encarna las cosas y adapta a sí mismo de una manera simbólica. Incluyen actividades físicas, disfrutan de correr y saltar. Según Piaget, el juego simbólico permite reforzar el egocentrismo del niño, adaptando la realidad a sus propios matices (Gaztelaniaz, 1990). A partir 
de los 6 años los niños comienzan a jugar con reglas, participan en un grupo de amigos y cooperan. A través de un juego con reglas, el niño acepta la realidad. En esta etapa, el juego simbólico disminuye: a medida que el niño acepta la realidad, en lugar de transformar la realidad a través del juego simbólico, la realidad formará parte de su vida.

\section{iii. Juegos infantiles clásicos}

Las escondidas, por ejemplo, es un juego infantil conocido en todo el mundo donde un niño tiene que buscar a otros niños que se esconden. El área de juego para las escondidas es cualquier área interior o exterior la cual ofrece oportunidades para esconderse de los ojos del buscador. (Hirling, 2008). Si bien los niños más pequeños suelen estar satisfechos con un espacio pequeño como una sala, un árbol o arbustos en el jardín, los niños mayores necesitan un área más grande con escondites más rebuscados para ser desafiados. El niño que tiene que buscar, generalmente seleccionado por decisión del grupo, mantiene los ojos cerrados o tapa sus ojos con las manos, contando en voz alta hasta un cierto número que los demás niños puedan oírlo. Durante este tiempo, cada niño busca el mejor escondite posible en la casa o al aire libre. Si el niño que cuenta ha llegado al número especificado, agrega una frase diferente. Por ejemplo: "Quieran o no, allá voy". Es ahí en donde abre sus ojos y comienza a buscar a los otros niños. Dependiendo de la variante, si ha encontrado un niño, debe tocarlo o incluso llamarlo por su nombre (“iAmpay Rafael!”). Los niños descubiertos así son encontrados o atrapados. Como castigo, el siguiente buscador suele el primer niño encontrado. El juego termina cuando todos los niños han sido encontrados. (Williams, 2009)

Las chapadas, las atrapadas, la pega, también llamada la pega pega; es un juego popular en el mundo entero. Puede ser jugado por un número ilimitado de jugadores y posee innumerables variantes. (Vitoria, 2008). En general, el juego consiste en dos tipos de jugadores, los que atrapan y los que deben evitar ser atrapados. Cada variante del juego posee una forma diferente de establecerse como los demás serán atrapados, en general por medio de un toque. Quien sea tocado, automáticamente se convierte en el que atrapa, dependiendo del modo de juego. 
El juego del yas, conocido en España como "mata nenas" y juego de tabas, en el mundo entero, es uno de los juego más antiguos del planeta. Es normalmente practicado por niñas. Es un juego compuesto por piezas que, originalmente, eran piedras pulidas, sin embargo en la actualidad han sido remplazadas por pequeñas piezas de plástico. Los jugadores lanzan las piezas del juego en el aire e intentan coger el mayor número posible en la parte trasera de una mano mientras caen. Quien tome el mayor número de piedras gana. (David, 1962). En países de Latinoamérica se utiliza una pequeña bola de goma la cual hace al juego más complejo, también se agrega variaciones entre las piezas.

El matagente, también conocido como balontiro, quemado, matasapo; es un juego de deportes que probablemente se originó en Colombia. Es considerado como uno de los juegos infantiles más populares que se juega tanto en escuelas como en barrios populares. Este juego se realiza lanzando una pelota de goma a un oponente. Según la página oficial de Dodgeball, matagente en inglés, existen tres sistemas de juego diferentes para determinar el ganador: el sistema de eliminación, el sistema de tiempo y el sistema de puntuación. En el sistema de eliminación, el equipo ganador es el primer equipo que elimina con éxito a todos los miembros del equipo contrario. Mientras tanto, el sistema de tiempo usa el tiempo como un juego limitante y el equipo con el mayor número de jugadores que aún sobreviven es el ganador. En el sistema de puntuación, el cálculo del valor se realiza al final de la partida al observar el número de jugadores que aún están en el campo.

La liga es considerada uno de los juegos más desarrollados en patios escolares. Este juego para niños depende de la habilidad, el ritmo y el control del cuerpo del infante. El nombre proviene de la utilización de una liga como único elemento del juego. Generalmente existen tres participantes, aunque también se puede jugar solo o en pareja, sin embargo se requiere de una opción de sujeción, como un poste, letrero, silla, cubo de basura, etc., para asegurar la banda elástica. Las reglas varían de país a país, de ciudad a ciudad, incluso de escuela a escuela. En su mayoría se transmiten oralmente y se modifican y reinventan. El principio básico, sin embargo, sigue siendo el mismo: la liga se estira alrededor de los pies de dos participantes. Estos se enfrentan uno al otro, uno frente al otro. Un tercer jugador salta dentro, en o entre esta liga en ritmos previamente acordados. 
Si el jugador comete un error, pierde el juego, sin embargo si tiene éxito, aumenta su nivel de dificultad. (Gaussot, 2001)

Junto con la liga, el mundo, también llamado rayuela, paraíso o viaje a la luna es un juego infantil muy popular convirtiéndose en un juego de salto muy frecuente en los patios escolares. Este juego tradicional es uno de los más antiguos de la tierra: investigadores han encontrado diafragmas de este juego tallado en piedra en la antigua Roma. Se ha extendido desde Asia menor hasta el norte de Europa, en donde los romanos crearon superficies ideales para este juego de salto. Dado que los arqueólogos no pueden encontrar líneas dibujadas en la tierra, la historia de cómo se distribuyó por el planeta sigue siendo un misterio. Las reglas de este juego son tan variadas como los patrones, principalmente se suele dibujar con ayuda de una tiza o algún elemento que raye el asfalto un plano con números del 1 al 100. Se empleará un pequeño elemento para ser lanzado, comúnmente se utiliza una piedra, aunque también se suelen usar cadenas o pulseras. En una variante simple, la piedra debe lanzarse de la caja 10 a la caja 90 . Si se da en el campo correspondiente, se comienza a hacer autostop, es decir, a saltar sobre una pierna. Dependiendo de la variante, el juego se divide en rondas, al comienzo de la siguiente ronda, la piedra debe lanzarse un espacio más que en la ronda anterior. El primero en tirar en el último campo y saltar correctamente ha ganado. Si se comete un error en el lanzamiento, por ejemplo, si la piedra cae fuera de la línea, o si se desequilibra, el jugador perderá su turno. (Hirling, 2009)

\section{b. Modernos}

\section{i. Individuales}

En los videojuegos, el término jugador individual o un jugador se refieren a una variante de un juego en particular en el que solo juega un jugador. El juego para un jugador describe un juego que solo proporciona un jugador, mientras que el modo multijugador se refiere a un juego para varios jugadores. La mayoría de los primeros juegos por computadora solo proporcionaban un jugador. Actualmente la mayoría de las consolas de videojuego están diseñados para ser jugados por una sola persona, aunque muchos juegos tienen modos de dos 0 más jugadores. 
La mayoría de veces, como jugador individual, juegas una historia predefinida por el desarrollador en muchas áreas hasta el final del juego, en contraste con el modo multijugador, donde el jugador generalmente compite contra jugadores humanos sin una secuencia de acción definida. (Hans-Joachim, 2008). La historia jugada en el modo de un solo jugador es también llamada misión o campaña. Al estructurar el juego, por ejemplo, en niveles individuales, el diseñador del juego posee un mayor control sobre los desafíos que el jugador encontrará en el juego. Esto se puede manejar de manera diferente al ajuste del nivel de dificultad como en los títulos de varios jugadores y el flujo de información que debe controlar el jugador para otorgarle algunas opciones de planificación. Además, los títulos de un solo jugador pueden incluir influencias individuales de la temporada como la inserción de no jugar. (Bjork \& Holopainen, 2005)

En principio, los títulos para un solo jugador en sí no implican ninguna posibilidad de interacción social inmediata. Sin embargo, jugar tales juegos en presencia de otras personas, en una cabina de internet, puede provocar una interacción social espontánea entre el jugador y el espectador. Otras opciones incluyen el uso de tablas de puntaje alto que permiten la comparación del rendimiento del juego. También existe la realidad virtual del juego que conecta puntos entre jugadores del mismo título con un solo jugador. Esto puede provocar interacciones sociales en el juego, como el intercambio de experiencias o la asistencia mutua, especialmente en juegos con estructuras narrativas u opciones de exploración que pueden no ser obvias para todos los jugadores. (Bjork \& Holopainen, 2005). La ayuda y asistencia de otros jugadores puede resumirse como una solución completa al juego que será publicada en Internet. Esta es una forma de intercambio derivado muy común actualmente, generalmente son videojuegos grabados por los jugadores y comentados verbalmente durante el juego. Una misión de un solo jugador puede ser compatible con múltiples jugadores a través del modo cooperativo. Varios jugadores conectados a través de una red participan en un juego que corresponde estructuralmente a una misión típica de un solo jugador.

\section{ii. Colectivos}

En los juegos de computadora, el modo multijugador se refiere a un tipo de juego en el que uno juega con o contra otras personas. Es la contraparte del juego de 
un solo jugador, donde un solo jugador juega solo con la computadora. Los juegos de computadora multijugador son, hasta cierto punto, la extensión de los juegos de mesa al mundo digital. Permiten que varias personas jueguen juntas usando computadoras o consolas de juegos. El atractivo de interactuar con la computadora es experimentar experiencias de juego compartidas con otras personas, posiblemente distantes o hacer una comparación directa del rendimiento con personas reales. Por lo tanto, la experiencia de juego difiere significativamente del modo de un solo jugador, donde no tiene lugar la interacción social. En algunos casos, los jugadores solo encuentran el desafío deseado entre jugadores humanos, ya la inteligencia artificial de una computadora presenta comportamientos esquemáticos y fácilmente predecibles. La comunicación entre jugadores humanos que no juegan en el mismo espacio real se puede realizar a través de chat textual, comunicación de voz directa por medio de micrófono y auriculares o videollamada.

El modo multijugador surgió con uno de los primeros juegos de computadora "Tennis for two" del año 1958, en el que dos jugadores intentaron jugar con un respectivo oponente. Incluso las primeras máquinas comerciales de arcade como "Pong" de 1972 ofrecían solo un modo multijugador. La razón de esto era que en ese momento la programación de los oponentes en la computadora todavía se consideraba demasiado lenta, y el modo de un solo jugador aún no había sido reconocido como un modelo de negocio lucrativo. (Donovan, 2010) Los primeros videojuegos para el mercado privado tales como "La Odisea" de Magnavox, "Atari 2600" o "Philips G7000" fueron diseñados principalmente para juegos con dos compañeros de equipo. Para el "Atari 1977" hubo incluso un juego para cuatro jugadores con Video Olympics. Desde finales de la década de 1970, los juegos prevalecieron cada vez más, ofreciendo un modo para un solo jugador. Aunque algunos juegos, especialmente las máquinas recreativas, todavía ofrecían nominalmente el modo multijugador, esto consistía únicamente en el hecho de que los jugadores alternaban y jugaban uno tras otro individualmente contra la computadora. Desde la década de 1970, en universidades y escuelas, los juegos multijugador más complejos surgieron como proyectos de estudio. (Bright, 2010). Solo en 1983 llegó el juego "MULE", el primer juego de computadora multijugador de múltiples capas en el mercado 
abierto. Fue el pionero en permitir a cuatro jugadores una interacción simultánea. En 1987, el primer juego comercial apareció con "MIDI Maze", en el que participaban hasta 16 jugadores, los cuales no necesitaban estar sentados en la misma computadora, sino cada uno jugaba con computadoras individuales conectadas a través de una red local. En 1988, "Modem Wars" fue el primer juego comercial en línea en el que dos personas muy separadas podían jugar entre sí a través de módems. Desde entonces, una gran variedad de modos de juego multijugador han evolucionado con sus propias reglas. Los modos multijugador más jugados se pueden encontrar en juegos del género ego-shooter como "Counter-Strike", "Battlefield", "Unreal Tournament", "Quake III Arena" y juegos de estrategia en tiempo real como "Warcraft III", "StarCraft", "Blitzkrieg". Un género especial son los juegos de rol masivos en línea multijugador, también llamado los MMORPG, ya que son juegos de rol que solo existen en el modo multijugador.

\section{Seguridad ciudadana y la calle}

\section{a. Cómo influencia la seguridad y jugar en la calle}

"Por cuestiones de seguridad y de estilos de vida, así como el cambio en los valores, juguetes, actividades de los niños, jugar en la calle comienza a ser un término extraño". (Morgado 2016). Existen diversos estudios que subrayan la importancia del juego al aire libre, especialmente si es en la calle, situación que ha desaparecido de la vida de muchos niños y adolescentes.

La Sociedad para Prevención de Accidentes (RoSPA) de Inglaterra cita lo siguiente: "el niño debe estar tan seguro como sea necesario". Según el sociólogo y educador José Morgado, esta cláusula le parece excesiva y asfixiante, ya que inhibe a los niños experiencias y actividades contributivas para la capacidad de gestión de límites y riesgos, así como para el aumento de la autonomía de los niños, el cual es factor nuclear en su desarrollo y educación. "Los niños y niñas no tienen que ver jugar a la calle como una experiencia peligrosa y negativa, sino deben conocer los riesgos, límites y estrategias de protección, así mismo, esto los beneficiaría en la superación de dificultades o incidentes" (2016). La importancia de que padres y educadores asuman una actitud más flexible y abierta, junto con la convicción de que sigan velando por la seguridad de los más pequeños es también parte de la opinión de Morgado. 
En el año 2007, el reconocido escritor español Juan José Millas se hizo acreedor al premio Planeta por su obra "El mundo". El libro narra las emociones del jugar en la calle en la infancia enfocada en sus propias experiencias. Millas dijo al momento de recibir el galardón "Cuántas historias y experiencias de muchos de nosotros cargan de jugar y caminar en la calle y que han contribuido de formas diferentes a lo que somos y a lo que nos gusta".

El eje central de la acción educativa escolar o familiar es la autonomía, la capacidad y la competencia para tomar cuenta de sí (Negreiros, 2016). La calle, la apertura, el espacio, los desafíos, los límites y las experiencias son herramientas fortísimas para el desarrollo y promoción de esta autonomía.

\section{Lima}

En el año 1562 Lima contaba con unos 16.000 habitantes. En 1861, la población superaba el límite de 100.000 y para 1927, este número se había duplicado. Hoy en día, alrededor de siete millones de personas viven en Lima. La mayoría se vienen asentando en la periferia, de modo que la ciudad se expande en dirección norte y sur. La población de la ciudad se ha multiplicado por ocho en las últimas cinco décadas: En 1951 vivieron en la ciudad de 835.000 personas, y los resultados del censo del 2007 fueron de 6.960.943 y 8.574.974 en el 2017 (INEI, 2017). De estos, $91 \%$ tienen español y $8 \%$ quechua como su idioma nativo. La densidad de población es de 3209 habitantes por kilómetro cuadrado. Actualmente 910,431 personas viven en los suburbios y áreas rurales fuera del centro de la ciudad. El área metropolitana de Lima incluye los 43 distritos de la provincia de Lima y los seis distritos de la región del Callao con un total de 10 , 479,899 habitantes (2017).

Desde mediados del siglo $\mathrm{XX}$, aparecieron asentamientos marginales que surgieron de las invasiones de tierras: los denominados "pueblos jóvenes", en la que hoy viven aproximadamente dos tercios de la población de Lima. En términos de planificación urbana, estos se consideran asentamientos informales. Muchos de estos asentamientos humanos se encuentran actualmente en un proceso de consolidación gradual, a pesar de la falta de servicios básicos. En los últimos años, el crecimiento de la población de Lima se ha desacelerado y las entradas rurales están ahora más concentradas en las ciudades del centro de 
Perú. Dado que la mayor parte del crecimiento de las últimas décadas se debe a la ocupación de terrenos y la autoconstrucción en las afueras de la ciudad, casi no existe una construcción compacta de viviendas con casas multifamiliares. Toda la ciudad, con algunas excepciones, se caracteriza por viviendas unifamiliares con uno a tres pisos de diferente calidad. (Lloyd, 1980)

\section{a. Barrios populares}

El prototipo de una metrópolis latinoamericana con una pronunciada cultura de barrio es Lima. A finales del siglo XX, cada año llegaban a Lima hasta 200,000 personas de áreas rurales. Varias décadas antes, la clase media alta se había alejado del abarrotado centro de la ciudad. Se fundaron nuevos vecindarios como Miraflores o San Isidro, mientras que los muy ricos se mudaron a Monterrico y La Molina, al este de Lima. En barrios intermedios vivieron miembros de las clases media y baja.

En Lima, un barrio popular es sinónimo de vecindad, de hermandad y confraternidad. Es un espacio estrecho donde se reúnen diversos desarrollos sociales, culturas y personas. Las posibilidades concretas ofrecidas por el barrio influencian las posibilidades de sus habitantes puedan transformarse y desarrollarse. La vivienda y su entorno inmediato, la organización y la seguridad de los espacios públicos, posibilidades de acceso a la educación, acceso al transporte público y estructuras de abastecimiento definen la calidad de vida y las perspectivas de los habitantes. (Elias, 2002).

En las últimas décadas, los distritos y sus barrios han demostrado que disponen de gran fuerza de integración social y que ofrecen oportunidades de desarrollo social y económico. Son generalmente sinónimo de prosperidad e innovación, pero también lugares de desafíos especiales para la integración. El envejecimiento de la sociedad, la desigualdad social, la segregación, los problemas ambientales, las tensiones sociales y conflictos son especialmente evidentes en los distritos y sus barrios. Esta problemática es confirmada por el cuarto informe del gobierno peruano sobre pobreza y riqueza emitida en el año 2013. Este informe demuestra que el barrio y su origen social son decisivos en cuanto al nivel de instrucción, a las oportunidades del ascenso y el éxito de la prevención contra la pobreza. (2013) El barrio puede abrir oportunidades y perspectivas, pero también puede disminuirlas. Es principalmente en la elección 
del lugar de vivienda y de la escuela, en conexión con el miedo de declinación social, que se observan las tendencias a la segregación.

\section{b. Contexto social en los barrios populares}

La vida cotidiana de los residentes de varios barrios, sobre todo cuando son en zonas periféricas, de alguna manera es bastante pintorescos. Como Prost (1992) observó, son sonrisas, saludos, saludos que hacen de los barrios verdaderos escenarios de reconocimiento, de ser conocido y reconocido, apreciado y estimado.

Es en la sociabilidad construida cotidianamente que diversos actores sociales viven y conviven con sus iguales, participando de varias actividades en conjunto; principalmente cuando estas actividades están orientadas hacia el ocio; se reúne para resolver los problemas comunes: como la falta de energía eléctrica o ir al funeral de algún vecino, en este caso el vecino se vuelve una figura más que importante en la convivencia social. El barrio, de ese modo, no es sólo una demarcación territorial que divide la ciudad sino es la constitución de una ciudad, donde los vecinos que en él habitan se identifican, sociabilizan, crean lazos afectivos y sentimientos de pertenencia y, sobre todo, tradiciones. En el barrio se percibe dificultades y problemas. Problemas con el crecimiento poblacional, con infraestructura, con la violencia, con la falta de servicios, con la falta de empleo, etc. En este sentido, el barrio es el espacio de interacción mutua (Prost, 1992), la armonía, los trabajadores, el buen vecino, amistad, ocio, es también la vecina chismosa, la bodega de la esquina, entre otros.

El barrio convierte lo privado en público, es decir, permite a los vecinos participar y compartir un estilo de vida común, donde los residentes reconocen a sus compañeros, lo que hace del barrio una gran área privada, pero al el mismo tiempo es público al no ser cerrado y restringido sólo a un determinado grupo social. (Elias, 2002).

Un barrio digno de vivir es aquel con el que sus habitantes se identifican y que es utilizado y apreciado por personas de los barrios circundantes. Es un barrio activo cuyos habitantes participan y se comprometen, y está marcado por un trato de respeto mutuo entre las personas. Esto requiere una política de barrio holístico en que organización coloca el ser humano en el centro de la acción. El 
desarrollo del barrio junto con sus residentes y para ellos requiere también considerar la creciente diversidad de situaciones sociales, intereses y valores. Sólo así se puede garantizar que sus habitantes se comprometen por su barrio.

\section{E. Comunicación personal}

\section{a. Comunicación tradicional}

La comunicación es un proceso que implica el intercambio de información entre dos o más personas a través de signos o símbolos mutuamente comprensibles. Es un proceso social primario, que permite crear e interpretar mensajes que desencadenan a una respuesta. (Griffin, 2011)

Los pasos básicos de una comunicación efectiva son las motivaciones o la intención de comunicar, la composición del mensaje, la codificación y transmisión de los mensajes codificados, la recepción de las señales, la decodificación y finalmente la interpretación del mensaje por parte del receptor. El proceso de comunicación se define por la tecnología de comunicación, las características de los remitentes y los destinatarios de la información, sus códigos culturales de referencia, sus protocolos de comunicación y el alcance del proceso. (Castells, 2009).

La comunicación incluye cuestiones técnicas (por ejemplo, telecomunicaciones), biológicas (por ejemplo, la fisiología, la función y la evolución) y sociales (por ejemplo, el periodismo, las relaciones públicas, la publicidad, audiovisuales y medios de comunicación).

Para la semiótica, el acto de comunicar es la materialización del pensamiento de signos conocidos por las partes involucradas. Estos símbolos son transmitidos y reinterpretados por el receptor. También es posible pensar en nuevos procesos de comunicación, que engloban las redes colaborativas y sistemas híbridos, que combinan comunicación de masa y comunicación personal.

La comunicación es un concepto histórico y polisémico, que evolucionó entre los siglos XIX y XX, siendo definida, en un primer momento, como un conjunto de canales y medios para finalmente ser considerada como la positividad formada de las prácticas, discursos e ideales establecidos por una transmisión social de mensajes de las llamadas tecnologías de comunicación. (Castells, 2009) 
Es necesario considerar diferentes métodos de comunicación según la evolución de sus periodos: la comunicación corporal, oral, la escritura y la digital. De la misma manera, varios aspectos de la comunicación han sido objeto de estudios. Por ejemplo, en la antigua Grecia, el estudio de la retórica, el arte de hablar y persuadir, era una cuestión vital para los estudiantes. El desarrollo de la comunicación humana debe ser explicado por una teoría de transiciones, según Melvin DeFleur y Sandra Rokeach. Uno puede hablar de cinco etapas: el desarrollo de la señalización, el habla, la escritura, la impresión y la comunicación en masa. (DeFleur \& Rokeach, 2011). El primer paso fue en la prehistoria en donde la capacidad cerebral aumentaba lentamente y a su vez la comunicación mejoraba y los sistemas basados en símbolos y señales se fueron haciendo más elaborados y efectivos. Al considerar el lenguaje como un sistema de comunicación, los signos visuales y pictográficos también se califican relevantes en ese proceso. En este sentido, las formas gráficas primitivas, pictóricas o convencionales se consideran implícita o explícitamente como mensajes de comunicación (Raymond, 1992, p. 268). Los objetos, acciones y personas no pueden ser fácilmente separados de sus propios símbolos léxicos, de modo que los signos y símbolos pictóricos operan a través de un canal de lingüística, así como un canal visual (Raymond, 1992, p. 269).

Los seres humanos, con la aparición del Hombre de Cromañón, entran en la era del habla y del lenguaje aproximadamente entre 90 y 40 mil años atrás. En esa época, se realizaban representaciones de animales y seres humanos en huesos, piedras, marfil y otros materiales. Por otros cinco mil años más los seres humanos han hecho la transición de solo el habla a la era de la escritura, que fue inventado independientemente en más de una parte del mundo. (DeFleur \& Rokeach, 2011). Muchos años más tarde, en la mitad del siglo XV, llegó la época de la prensa. El primer libro fue producido por una prensa que usaba móviles fundidos en metal. Esta tecnología se extendió por toda Europa y partió hacia otras partes del mundo. Por último, surgió la era de los medios de comunicación, que de alguna manera se inició a principios del siglo XIX, con la llegada de periódicos y medios de comunicación como el telégrafo eléctrico y el teléfono. Junto con la radio, el cine y la televisión, estos medios promovieron la amplia expansión de la tecnología de la comunicación hasta la actualidad. (DeFleur \& 
Rokeach, 2011). La comunicación comenzó a ser considerada recién a principios del siglo XX, especialmente por el impacto que causó el surgimiento de nuevas tecnologías de comunicación. En siglos anteriores, como pasó en el silo XVIII y XIX, el término comunicación solo se refería a los medios de transporte y sus vías de comunicación: carreteras, autopistas, ferrocarriles, barcos, entre otros. Durante las tres primeras décadas del siglo pasado, fue visto como sinónimo de publicidad (Rudiguer, 2011). A inicios del siglo XX, muchos expertos comenzaron a estudiar la comunicación como una materia específica de sus disciplinas académicas, así mismo, la comunicación comenzó a emerger como un campo académico distinto. Marshall McLuhan, Theodor Adorno y Paul Lazarsfeld, fueron algunos de los pioneros en la zona. La comunicación ha evolucionado constantemente debido a las nuevas tecnologías y al uso de las redes sociales. La actual "era de las computadoras" viene transformando nuestra manera de comunicarnos, a tal punto que el siglo XXI es considerado la "sociedad de la información. (DeFleur \& Rokeach, 2011)

\section{i. Teoría de la comunicación}

Pensadores e investigadores de disciplinas de las ciencias humanas, tales como la filosofía, la sociología, la psicología y la lingüística, han realizado diversos análisis a lo que denominan " la teoría de la comunicación ": una visión general de ideas que apelan la comunicación entre las personas, en especial la comunicación mediada, como fenómeno social. En el siglo XX hubo una presión para realizar reflexiones teóricas reflejándolo en estudios empíricos con el advenimiento acelerado de los medios. Estas reflexiones sobre la comunicación apuntan a responder a la pregunta por la estructura, función y sentido de la comunicación en la sociedad. La comunicación social es un fenómeno complejo que no puede ser reducido a esquemas derivados de la teoría de la información, ya que ella no dispone de propia autonomía disciplinaria, pues se trata de una temática de investigación que se constituye necesariamente en el campo de una reflexión sobre los fundamentos de la vida social. (Rudiguer, 2011). La teoría de la comunicación es la disciplina encargada de desarrollar un programa de investigación en cuanto a la realidad social, la cual puede ser tematizada desde varios puntos de vista: desde pequeñas empresas, negocios, propagandas, 
medios de comunicación y las técnicas del proceso de comunicación (publicidad y el periodismo, etc. (Rudiguer, 2011).

\section{ii. Tipos de comunicación}

La comunicación depende del tipo de signo que usan los emisiores. En ese sentido, se puede hablar de la comunicación verbal y comunicación no verbal. En ocasiones, ambos signos se mezclan en un solo mensaje, dando lugar a una forma de comunicación mixta.

\section{La comunicación verbal}

El elemento principal de la comunicación verbal es la lengua y cualquier acto del habla implica un mensaje y otros cuatro elementos conexos: el emisor, el receptor, el tema o asunto del mensaje y el código utilizado. La relación entre ellos es variable. No existe en el dominio del lenguaje la propiedad privada, pues todo es socializado. La interacción verbal, como cualquier otra forma de interacción humana, requiere al menos dos interlocutores. El lingüista Roman Jakobson explica que un proceso normal de comunicación opera con un codificador y un decodificador. El primero recibe un mensaje, conoce el código; este mensaje es nuevo para él y, a través del código, la interpreta. (Jakobson, 2010)

El lenguaje humano se puede definir como un sistema de símbolos o signos lingüísticos, conocidos como lexemas y reglas gramaticales en la que se manipulan los símbolos. La lengua hablada utiliza fonemas como unidades de construcción, seguido de la unidad morfema como contrastivo y oraciones más complejas las cuales se construyen, de esta manera se elabora un mensaje (McGarry, 1999)

\section{La comunicación no verbal}

La comunicación no verbal es un medio para transmitir información que no utiliza el lenguaje hablado ni algún derivado de sonido (Mezquita, 1997). Implica los cinco sentidos existiendo interacción entre las personas sin que exista una interacción verbal. Los individuos también pueden comunicarse utilizando otras formas tales como expresiones faciales, la postura del cuerpo, distancia, etc. (Silva, 1996). La comunicación no verbal debe entenderse como acciones o 
procesos que tienen significado para las personas, con excepción de la expresión verbal. (Mezquita, 1997). Sin embargo, esto no se limita a la comunicación humana, ya que también se consideran otras formas, tales como la danza, la música, el teatro, la escultura, entre otros. (Mezquita, 1997). Este tipo de comunicación es en parte innato, a veces, imitativo y otras veces aprendido. En general, las diferentes partes del cuerpo pueden trabajar juntas para enviar el mismo mensaje, aunque a veces es posible enviar mensajes contradictorios, como cuando se está contando una historia divertida, pero su expresión es triste. (Torres, 2012)

Fue a comienzos del siglo XX que la investigación en la comunicación no verbal comenzó a producir interés, particularmente en lo que se refiere a la comunicación personal por medio de expresiones faciales. Los psicológicos observaron en esa época que el rostro no expresaba emociones de manera segura y fiel. Por lo tanto, los antropólogos observaron que los movimientos del cuerpo no son causales y que son legibles como un lenguaje. A medida que pasaba el tiempo, el interés público en la investigación sobre la comunicación no verbal aumentó considerablemente. (Davis, 1979). Se considera que un tercio del significado de los mensajes es transmitido por comunicación verbal y dos tercios por comunicación no verbal. También se dice que entre el 55-65\% de los mensajes recibidos provienen de la comunicación no verbal. (Silva, 1996).

Para el ser humano las comunicaciones no verbales son procesadas por medio de tres soportes: el primero es el cuerpo, en sus cualidades físicas, fisiológicas y en sus movimientos; el segundo es el hombre, es decir, objetos asociados al cuerpo como los adornos, ropas, marcas o cicatrices; y el tercer soporte refiere a la provisión de individuos en el espacio que va desde el espacio físico que rodea el cuerpo hasta el espacio en que se relaciona el espacio territorial (Mezquita, 1997). Los tipos de signos no verbales son: las acciones o movimientos corporales, el tacto, la postura corporal, las señales vocales, el espacio entre el emisor y el receptor, los objetos y adornos utilizados, el tipo de cuerpo de las personas involucradas en el proceso comunicativo y el momento en el que las palabras se expresan (Silva, 1996). En el caso de Knapp, se puede clasificar la comunicación no verbal en: paralelismo, modalidades de la voz; proxémica, uso del espacio por el hombre; táctil, lenguaje del tacto; 
características físicas, forma y apariencia del cuerpo; medio ambiente, disposición de los objetos en el espacio; y kinésicos, lenguaje corporal. (Silva, 2018)

En la comunicación intervienen múltiples variables e implica al mismo tiempo un proceso que se desarrolla en un continuo espacio temporal. La comunicación no tiene principio y fin bien definidos ya que los actos comunicativos son parcialmente indeterminables y, de algún modo, infinitos. El acto comunicativo es, precisamente, un proceso que implica la interacción social y cognitivo (Sousa, 2006). Por lo tanto, uno puede hablar de formas de comunicación humana (Sousa, 2006)

\section{Comunicación intrapersonal}

La comunicación intrapersonal es la que se realiza consigo mismo. Se produce siempre en un contexto organizado, es decir, en un plano articulado del sistema psicológico del individuo. Por ejemplo, se utilizan frases introspectivas y formas de pensamiento automático (Sousa, 2006). La comunicación intrapersonal se realiza cuando los procesos de comunicación se internalizan y son autoregulados (Torres, 2012). Se refiere el nivel básico de la comunicación humana y que el proceso de pensamiento interno, donde se conciben ideas para ser transmitidos e interpretados, son codificados y decodificados de forma permanente. (Wels, 2005)

El proceso se establece de manera personal, por medio de mecanismos conscientes, como pensamientos, planes; o inconscientes, como los sueños. Sobre todo es un proceso mental que puede contemplar también otras formas. Hay muchas maneras de que alguien se comunique consigo mismo, como cuando el individuo se ve al espejo y hace gestos que ayudan a comprender la intensidad de las emociones o cuando alguien toca un piano, es en la música a la que recurre como instrumento de comunicación. La comunicación intrapersonal es producida para dar sentido a nuestra propia existencia; para reflexionar sobre los demás, el mundo y ellos mismos. (Sousa, 2006)

\section{Comunicación interpersonal}


La comunicación interpersonal se produce entre dos individuos dentro de un pequeño grupo el cual representa la unidad social básica de una organización, lo que permite el desarrollo de relaciones humanas (Wels, 2005). Se presenta cuando se intercambian con otras personas información, intenciones, significados, deseos, emociones, entre otros, para sugerir, mandar, responder, preguntar, etc. Se produce, por ejemplo, cuando se llama por teléfono, al enviar una carta o un correo electrónico. Este tipo de comunicación integra más elementos en el contexto de la comunicación, como componentes no verbales (gestos, posición de los brazos, espacio físico entre los interlocutores, posición del cuerpo, expresiones faciales, etc.) y es tan relevante como la comunicación verbal (las palabras en sí). Esta clase de interacción interfiere directa e inmediatamente y es de procedimiento en el acto comunicativo interpersonal a través de percepciones, distancias, entonación, entre otros. (Sousa, 2006)

\section{Comunicación grupal}

A diferencia de la comunicación interpersonal, esta se realiza en el seno de grupos más grandes como familias, grupos de amigos o pequeñas asociaciones. Los grupos pueden formarse de diferentes maneras. La familia, por ejemplo, se forma en base a relaciones de consanguinidad, parentesco o similares. El grupo de amigos se forma por afinidades. Usualmente, los grupos mantienen una relación interpersonal directa de comunicación, cuyos comportamientos están determinados por las personalidades o roles que desempeñan dentro.

\section{b. Comunicación tecnológica}

La comunicación tecnológica se define como cualquier comunicación humana que se produce mediante el uso de dos o más dispositivos electrónicos. (Roudiger, 2011). Si bien el término se ha referido tradicionalmente a aquellas comunicaciones que se producen a través de formatos mediados por computadora, como mensajería instantánea, correos electrónicos, salas de chat, foros en línea, servicios de redes sociales; también se ha aplicado a otras formas de interacción basada en texto, como mensajes de texto. (Roudiger, 2011). La investigación sobre la comunicación tecnológica se centra principalmente en los efectos sociales de diferentes tecnologías de comunicación soportadas por computadora. Muchos estudios recientes involucran redes sociales basadas en Internet soportadas por software social. 
La comunicación mediada por computadora se puede dividir en dos formas: síncrona y asíncrona. (Griffin, 2011). La comunicación sincrónica mediada por computadora se refiere a la comunicación que ocurre en tiempo real. Todas las partes se comprometen en la comunicación simultáneamente; sin embargo, no están necesariamente todos en el mismo lugar. (Castells, 2009). Ejemplos de comunicación sincrónica son los chats de video y las llamadas de audio por Face Time. Por el contrario, la comunicación asíncrona mediada por una computadora se refiere a la comunicación que tiene lugar cuando las partes involucradas no se comunican al unísono. En otras palabras, el remitente no recibe una respuesta inmediata del receptor. La mayoría de las formas de tecnología mediada por computadora son asíncronas. (Castells, 2009). Ejemplos de comunicación asíncrona son mensajes de texto y correos electrónicos.

Académicos de una variedad de campos estudian fenómenos que pueden denominarse bajo el término de comunicación mediada por computadora (CMC). Muchos adoptan un enfoque socio psicológico de la CMC al examinar cómo los humanos usan computadoras, o medios digitales, para gestionar la interacción interpersonal, formar impresiones, establecer y mantener relaciones. (DeFleur, 2011). Estos estudios a menudo se han centrado en las diferencias entre las interacciones dentro y fuera de línea, aunque las investigaciones contemporáneas están avanzando hacia la idea de que La CMC debería estudiarse como parte de la vida cotidiana. (Haythornthwaite \& Wellman, 2002). Otra rama de la investigación de la CMC examina el uso de características paralingüísticas como los emoticones, reglas pragmáticas en el análisis secuencial y la organización de la conversación y los diversos sociolectos, estilos, registros o conjuntos de terminología específicos de estos entornos. (Arrenque 1999). El estudio del lenguaje en estos contextos generalmente se basa en formas de CMC basadas en texto, y denominándolas a veces "análisis del discurso mediado por computadora" (Arrenque, 1999)

La forma en que los humanos se comunican en entornos profesionales, sociales y educativos varían ampliamente, dependiendo no solo del entorno, sino también del método en el que se produce la comunicación, que en este caso es a través de computadoras u otras tecnologías de la información y la comunicación (TIC). El estudio de la comunicación para lograr la colaboración (productos de trabajo 
comunes) se denomina colaboración asistida por computadora e incluye solo algunas de las preocupaciones de otras formas de investigación de la CMC. Las formas más populares de CMC incluyen: correo electrónico, video, audio o chat, mensajería instantánea, servidores, etc. Estas configuraciones vienen cambiando rápidamente con el desarrollo de nuevas tecnologías. Los blogs también se han hecho populares, y el intercambio de datos RSS han permitido a los usuarios convertirse en su propio editor.

\section{i. Características}

La CMC, comunicación mediada por computadora, se examina y se compara con otros medios de comunicación a través de una serie de aspectos que se consideran universales para todas las formas de comunicación, incluidos, la sincronía, la persistencia y el anonimato. La asociación de estos aspectos con las diferentes formas de comunicación varía ampliamente. Por ejemplo, la mensajería instantánea es intrínsecamente síncrona pero no persistente, ya que se pierde todo el contenido cuando se cierra el cuadro de diálogo a menos que se haya configurado un registro de mensajes o se haya copiado la conversación manualmente. El correo electrónico y los tableros de mensajes, por otro lado, tienen poca sincronía ya que el tiempo de respuesta varía, ya que los mensajes enviados y recibidos se guardan. Las propiedades que separan al CMC de otros medios también incluyen la transitoriedad, su naturaleza multimodal y su relativa falta de códigos de conducta que estos rigen. (McQuail, 2005). La CMC puede superar las limitaciones físicas y sociales de otras formas de comunicación y, por lo tanto, permite la interacción de personas que no comparten físicamente el mismo espacio. El medio en el que las personas deciden comunicarse influye en la medida que las personas divulgan su propia información personal. La CMC está marcada por niveles más altos de auto-revelación en la conversación en lugar de las interacciones cara a cara. (Jiang, 2011). La auto-divulgación se define como cualquier comunicación verbal de información, pensamiento y sentimiento personalmente relevante que establece y mantiene relaciones interpersonales. (Jiang, 2011). De acuerdo al modelo de comunicación hiperpersonal de Walther (1996), la comunicación mediada por computadora es valiosa para proporcionar una mejor comunicación y mejores impresiones iniciales. Además, Ramírez y Zhang (2007) indican que la comunicación 
mediada por computadora permite más cercanía y atracción entre dos personas que una comunicación cara a cara. (Dunn, 2013). La gestión de impresiones en línea, la auto-revelación, la atención, la expresividad, la compostura y otras habilidades contribuyen a la competencia en la comunicación mediada por computadora. De hecho, existe una considerable correspondencia de habilidades en la interacción cara a cara mediada por computadora a pesar de la existencia de una gran diversidad de herramientas de comunicación en línea. (Bubas \& Spitzberg, 2013). El anonimato y, en parte, la privacidad y la seguridad dependen más del contexto y del programa en particular que se utilice o de la página web que se visite. Sin embargo, la mayoría de los investigadores en el campo reconocen la importancia de considerar las implicaciones psicológicas y sociales de estos factores junto con las limitaciones técnicas.

\section{ii. Beneficios}

La naturaleza de la comunicación tecnológica significa que es fácil para los individuos comunicarse con otros sin importar el tiempo o la ubicación. La comunicación mediada por computadora permite que las personas colaboren en proyectos que de otra forma serían imposibles debido a factores tales como la geografía. (Crum, 2012). Al permitir que una persona se comunique en el lugar de su elección, la llamada CMC ayuda a que una persona se comunique con un esfuerzo mínimo. (Carril, 2016). Hacer que un individuo se sienta cómodo a través de CMC también juega un papel en la auto-divulgación, lo que permite que un compañero comunicativo se abra más fácilmente y sea mucho más expresivo. Cuando se comunican a través de un medio electrónico, las personas tienen menos probabilidades de concebir estereotipos y son menos conscientes de las características físicas. El papel que desempeña el anonimato en la comunicación en línea también puede alentar a algunos usuarios a ser menos defensivos y establecer relaciones con otros más rápidamente. (Carril, 2016)

\section{iii. Desventajas}

Si bien la comunicación mediada por computadora puede ser beneficiosa, la mediación tecnológica también puede inhibir el proceso de comunicación. (Schouten, 2009). A diferencia de la comunicación cara a cara, las señales no verbales como el tono y gestos físicos, que ayudan a transmitir el mensaje, se pierden a través de la comunicación tecnológica. (Schouten, 2009). Como 
resultado, el mensaje que se está comunicando es más vulnerable a ser mal interpretado debido a una interpretación incorrecta del tono o el significado de la palabra. Además, según el Dr. Sobel-Lojeski de la Universidad de Stony Brook y el Profesor Westwell de la Universidad de Flinders, la distancia virtual que es fundamental para la comunicación tecnológica puede crear un sentido psicológico y emocional de desapego, que puede contribuir a los sentimientos de aislamiento social. (2016)

\section{c. Los niños y las tecnologías de comunicación}

La tecnología se ha convertido en una parte importante de la sociedad y de la vida cotidiana. Cuando las sociedades saben más sobre el desarrollo de una tecnología, pueden aprovecharla. Asimismo, cuando una innovación alcanza una importancia considerable, esta tecnología se convierte en parte de la sociedad. El uso de la tecnología en la educación proporciona a los estudiantes la alfabetización tecnológica, la alfabetización informacional, la capacidad para el aprendizaje y otras habilidades necesarias en el siglo XXI. (Puricelli, 2011). Desde la creación de computadoras se ha logrado un mejor enfoque para transmitir y almacenar datos. La tecnología digital se usa comúnmente para descargar música y ver películas en casa, ya sea en DVD o por servicios de streaming. Los registros de música digital, a diferencia de los medios de grabación tradicionales, son reproducibles, portátiles y gratuitos. (Walther, 1996)

Diversos países del mundo, especialmente los desarrollados, han comenzado a implementar tecnología educativa en escuelas, universidades y colegios. Según las estadísticas, a principios de la década de 1990, el uso de Internet en las escuelas era, en promedio, de $2 \%$ a $3 \%$. Continuamente, a fines de la década de 1990, la evolución de la tecnología aumenta rápidamente y llega al $60 \%$, y para el año 2008 casi el 100\% de las escuelas utiliza Internet de forma educativa. Según los investigadores del International Society for Technology in Education, las mejoras tecnológicas pueden llevar a importantes logros en las aulas. El sistema de aprendizaje electrónico ayuda a los estudiantes en el aprendizaje basado en proyectos y habilidades tecnológicas para resultados futuros en la motivación de los mismos.

A pesar de los beneficios de la tecnología en los niños, también hay efectos secundarios negativos. Dentro de este ámbito virtual, las plataformas de redes 
sociales como Instagram, Facebook y Snapchat han alterado la manera en que la cultura de esta generación, modificando la manera de cómo se ven a sí mismos. En los últimos años, se han realizado más investigaciones sobre el desarrollo de la depresión y su vinculación en redes sociales. La llamada "Depresión de Facebook" es cuando los usuarios se ven tan afectados por las publicaciones y las vidas de sus amigos que sus propios celos agotan su sentido de autoestima. Los niños y adolescentes se comparan con las publicaciones hechas por sus compañeros y se sienten indignos o monótonos porque sienten que sus vidas no son tan emocionantes como las vidas de otros. (Thurlow, 2004)

Otro ejemplo de los efectos negativos de la tecnología en los niños es la rapidez con que está empujándolos hacia la madurez. Con el mundo a su alcance, los niños pueden aprender todo lo que deseen. Con las fuentes sin censura de Internet y sin la supervisión adecuada, los niños pueden ser expuestos a material explícito en edades inapropiadas. (Walther, 1996). Esto se muestra al demostrar intereses prematuros al experimentar con maquillaje, al abrir una cuenta de correo electrónico o una página de redes sociales, todo cual puede convertirse en una ventana para depravados y otras entidades peligrosas que amenazan la inocencia de un niño. La tecnología tiene un efecto grave en la salud de los jóvenes. El uso excesivo de la tecnología está asociado con la privación del sueño, está relacionada con la obesidad y el bajo rendimiento académico en las vidas de los adolescentes. (Haythornthwaite \& Wellman, 2002).

\section{F. Teléfonos móviles y entretenimiento digital a. Smartphones}

Un teléfono inteligente, también conocido como smartphone, es un teléfono móvil que tiene capacidades de computadora y conectividad significativamente más completas que un teléfono móvil tradicional. Los primeros teléfonos inteligentes adaptaron las funciones de un asistente digital personal (PDA) o una tablet con la funcionalidad de un teléfono móvil. Posteriormente, el dispositivo compacto también tenía las funciones de un portátil: reproductor multimedia, una cámara digital y de video y un dispositivo de navegación GPS. 
Una característica clave de los teléfonos inteligentes modernos son las pantallas táctiles que controlan todas las funciones. Una conexión a Internet rápida se realiza mediante una conexión de banda ancha móvil a través del proveedor de servicios móviles o mediante WLAN. Una característica importante es que el usuario puede instalar fácilmente programas complementarios, llamadas aplicaciones, a través de un portal de descarga de Internet, por ejemplo una App Store, que está disponible para una amplia variedad de usos.

Los primeros teléfonos inteligentes ya existían a fines de la década de 1990, pero solo con la introducción del iPhone en 2007, ganaron una cuota significativa en el mercado. Hoy en día, la mayoría de los teléfonos móviles vendidos son teléfonos inteligentes. El acceso permanente a Internet provocó un cambio en el comportamiento del uso de Internet, especialmente en redes sociales como Facebook, Twitter e Instagram. Las enciclopedias en línea como Wikipedia también se benefician esta disponibilidad permanente, ya que los artículos también se pueden editar y las fotos se pueden cargar más fácilmente. El sistema operativo para teléfonos inteligentes más utilizado es el Android que utilizan casi todos los fabricantes. (Cuota de mercado por número del segundo trimestre de 2015, aproximadamente el 83\%), seguida por el Apple iOS utilizado solo en dispositivos Apple (cuota de mercado por números del segundo trimestre de 2015, aproximadamente el 14\%). (International Data Corporation, 2015)

\section{i. Características}

Los smartphones modernos pueden ser de gran utilidad gracias a una gran cantidad de funcionalidades dependiendo del equipo, como por ejemplo:

- Comunicación entre usuarios: teléfono móvil, navegador web, correo electrónico, SMS, MMS y telefonía IP (VoIP), mensajería instantánea (IM) $y$ chat, a veces fax, video llamada y circuitos de conferencias; pero también no intencionales: dispositivos de escucha, espionaje,etc.

- Administrador de información personal: (PIM) libreta de direcciones, agenda de citas, lista de tareas, bloc de notas, cumpleaños, etc. en comparación con una aplicación de computadora o a través de Internet.

- Dictáfono.

- Almacenamiento y envío de todo tipo de datos, en tiempo real. 
- Funciones multimedia con reproductor de medios, la radio, galería de imágenes, cámara de fotos y de video.

- Computadoras de bolsillo, por ejemplo, procesamiento de textos, hojas de cálculo, lectores de PDF, calculadoras.

- Navegación con sistema GPS y mapas o medios para determinar la propia ubicación por otros.

- Dispositivo para servicios basados en la ubicación, como la búsqueda de proximidad móvil.

- Consola de juegos móvil.

- Reemplazo de objetos cotidianos, por ejemplo un reloj, alarma, linterna, etc.

\section{ii. Ventajas y desventajas}

El "Enigma de Internet-AG" de la Universidad Johann Wolfgang Goethe de Frankfurt am Main abordó en 2013 la investigación de cómo los teléfonos inteligentes y las tablets influyen en la vida social. Los autores siguieron el principio guía de Karl Steinbuch: "Nada obliga al hombre a usar las posibilidades de la ciencia y la tecnología para su desgracia; todas las formas están abiertas para usar la ciencia y la tecnología en su propio beneficio". (Adam \& Ludwing, 2013) se llegaron a las siguientes conclusiones:

- Los smartphones permiten el acceso a un conocimiento ilimitado, siempre y en cualquier lugar, por lo tanto, pueden transformar a la sociedad en una "sociedad informada".

- Los smartphones permiten al usuario no solo ser un consumidor de contenido sino también un productor (redacción de textos, fotos, videos).

- La música se puede escuchar en cualquier momento y en cualquier lugar, al igual que fotos y videos.

- Ya no hay obstáculos para tomar una variedad de fotos.

- Ya no tienes que salir de casa para ir de compras.

- Datos de salud se podrán recopilar y transmitir de forma continua.

- Contactos sociales se pueden mantener de forma remota en tiempo real y de forma económica. 
En el libro "La epidemia del Smartphone: Riesgos para la salud, la educación y la sociedad" (2018), el neurólogo y psicólogo de medios de comunicación Manfred Spitzer, expone en su tesis que los teléfonos inteligentes contribuyen de manera especial a la demencia digital especialmente en aquellos que utilizan el medio de manera excesiva. Esto reduce la inteligencia promedio de las personas en aquellos países donde la digitalización está progresando fuertemente. Según Spitzer, el uso frecuente de teléfonos inteligentes conduce a inactividad física, obesidad, trastornos posturales, diabetes, hipertensión, miopía, insomnio, incremento en el número de accidentes y enfermedades de transmisión sexual, miedo, intimidación, trastorno por déficit de atención, depresión, tendencias suicidas, pérdida de la empatía, disminución de satisfacción con la vida, alcohol y adicción a las drogas, adicción a teléfonos inteligentes y los juegos en línea, menos educación, menos confianza mutua, menor capacidad para formar una voluntad, menos experiencia de la naturaleza, menos promoción de la sostenibilidad, más anonimato, menos solidaridad, más aislamiento social y soledad, menos salud de la población y una amenaza para la democracia. (Manfred, 2018, p. 149)

\section{b. Tablets}

Una tablet, tableta o bloc de notas es una computadora portátil con pantalla táctil sin teclado mecánico desplegable. Debido al diseño liviano y a la pantalla sensible al tacto, las tablets se caracterizan por su facilidad de uso. Los dispositivos son similares en cuanto a alcance, operación y diseño de los smartphones modernos y comparten similitudes en cuanto a sus sistemas operativos. Debido al teclado en pantalla, que solo aparece cuando es necesario, las tablets son menos adecuadas para escribir grandes volúmenes de texto. Así mismo estas suelen estar equipadas con baterías no extraíbles. Muchos de estos dispositivos se ofrecen con un módem integrado (incluido UMTS o LTE como radio de datos), por lo que el teléfono móvil se puede usar sin tener que depender de un módem móvil externo (como un puerto USB ). La conexión por cable a dispositivos externos no se proporciona para la mayoría de las tablets. Usualmente también se utilizan para el control remoto de dispositivos digitales, como cámaras, receptores AV, televisores, etc. 
Desde el punto de vista pedagógico, las tablets pueden ser utilizadas en diferentes aspectos del proceso de aprendizaje, desde la activación del conocimiento previo y mejora de la enseñanza, permitiendo el procesamiento del conocimiento didáctico a través de tareas de aprendizaje complejas, así como permitiendo la práctica de tareas parciales para evaluar el conocimiento y las habilidades del alumno. Por eso, varias escuelas integran las tablets en prácticas de enseñanza para conseguir una educación más activa y personalizada y fortalecer las habilidades individuales de sus alumnos. La encuesta anual en materia de Tablets y Conectividad, realizado en mayo de 2014 por la British Educational Suppliers Association, reveló que el $76 \%$ de las escuelas secundarias adoptaron el uso de tablet en sus clases. (van-Hove \& Vanderhoven, 2017)

\section{c. Consolas}

Una consola o consola de juegos electrónicos, también conocido como videojuego consola, es un microprocesador dedicado a ejecutar juegos de vídeo de diversos géneros, como juegos de tiro, juegos de acción, música y otros. La consola ejecuta un juego a la vez, pero que se puede intercambiar fácilmente de acuerdo al deseo del usuario. Los amantes de los videojuegos existen en ambos sexos y todos los grupos de edad, desde los niños hasta los adultos.

La biblioteca de títulos y estilos de juego para los jugadores es extensa y puede grabarse en un disco óptico, como CD 's, DVD ' s, BD 's, o medios especializados, como en el caso de la PSP y Game Cube, en el propio disco duro de la consola, en las tarjetas de memoria o cartuchos. En este tipo de juegos, se puede interactuar a través de órdenes dadas por un control que es usualmente llamado "mando". Actualmente también es posible controlar un videojuego a través de comandos de voz y gestos, así como funciones básicas de la consola, seleccionar un juego de la biblioteca, administrar el contenido de su disco duro, ajustar la fecha y la hora, etc. La información de los juegos se procesa en el interior del dispositivo y es puesto a disposición de los jugadores a través de una interfaz gráfica y de sonido. A su vez se presenta en algún dispositivo de audio y vídeo (TV, monitor de vídeo, auriculares, etc. de imágenes y animación, el habla, efectos de sonido y música) y, a menudo se tocan a través de la vibración de control o los auriculares. 
Los videojuegos han sido criticados por grupos de padres psicólogos, políticos y algunas organizaciones religiosas (BBC News, 2007) por presuntamente glorificar la violencia, la crueldad y el crimen, y por exponer a los niños a estos elementos. Para algunos es particularmente inquietante que algunos videojuegos les permitan a los niños representar delitos, por ejemplo la serie Grand Theft Auto, y que los recompensen por hacerlo. Las preocupaciones de que los niños jueguen videojuegos violentos se debe a que pueden desarrollar una tendencia a actuar más agresivamente en el patio de recreo. En vista de esta circunstancia se ha llevado a cabo la adopción de sistemas de calificación por parte de la industria, como el sistema de calificación ESRB en los Estados Unidos y el sistema de calificación PEGI en Europa. Su objetivo es educar a los padres sobre los tipos de juegos que sus hijos están jugando para permitirles tomar una decisión informada sobre si les permiten jugar. Los estudios han demostrado que la mayoría de los padres que se quejan de que sus hijos pequeños son cada vez más agresivos y violentos en el patio de la escuela debido a los videojuegos (Shepherd, 2012) ya que no siguen los sistemas de calificación de ESRB y PEGI.

Sin embargo, investigaciones llegan a la conclusión de que la violencia en los videojuegos no está relacionada con tendencias agresivas. Esta fue la conclusión de un estudio realizado en 1999 por el gobierno de los Estados Unidos, la cual llevó a cargo el cirujano general David Satcher al decir: "Asociamos la violencia de los medios con el comportamiento agresivo, pero el impacto es muy pequeño en comparación con otras cosas". Esta fue también la conclusión de un meta-análisis del psicólogo Jonathan Freedman, quien revisó más de 200 estudios publicados y encontró que la mayoría encontró ningún un vínculo causal. (1984)

\section{d. Problemas generados por el mal uso de la tecnología}

La dependencia de la tecnología, también conocida coloquialmente como adicción a la tecnología, se asigna como una dependencia de un subformulario de dependencias independientes de la sustancia, que consiste en el uso compulsivo de smartphones, tablets, juegos de computadora y video, entre otros. La sumisión a estos aparatos tecnológicos puede considerarse como una enfermedad porque restringe el grado de libertad de la persona en cuestión y, 
por lo tanto, resulta en una renuncia y pérdida de libertad. No está claro si el uso excesivo de juegos de computadora puede considerarse una enfermedad en el sentido de abuso y dependencia.

En Estados Unidos, el problema de la adicción a la tecnología ha generado mucho debate. La Asociación Médica Americana se reunió en junio de 2007, (Chicago Tribune, 2007) para discutir este problema, con el resultado de que se necesitan más investigaciones antes de que la dependencia de la tecnología se pueda considerar como un diagnóstico formal. Se solicitó a la Asociación Americana de Psiquiatría (APA) que investigue si el diagnóstico para su inclusión en el DSM-IV-Manual, diagnóstico y estadístico de trastornos mentales. Michael Brody, miembro de la Academia Americana de Psiquiatría Infantil y Adolescente, señaló que a pesar de que la tecnología podría ser adictiva, no cree necesariamente que el diagnóstico justifique su inclusión en el DSM. En una declaración oficial del 25 de junio de 2007, la APA anuncia que "actualmente no considera la dependencia a la tecnología como un trastorno mental".

\section{i. Físico}

La revista alemana especializada en temas médicos ÄrzteZeitung publicó en diciembre de 2018 los riesgos para la salud que ocasionan los smartphones. Después de meses de investigación se llegó a la conclusión lo siguiente:

- Los smartphones pueden llegar a ser adictivos.

- Dañan la espalda y las manos del usuario.

- Los consumidores que pasan mucho tiempo mirando su smartphones en la noche tienden a tener dificultades para conciliar el sueño.

- La luz azul de la pantalla podría dañar la retina de los ojos e incluso provocar ceguera.

- La radiación electromagnética de los smartphones podría causar cáncer.

- La operación inalámbrica de un smartphone causa radiación dañina.

- Un smartphones en el bolsillo de un pantalón en los hombres podría reducir la fertilidad. (Kieselbach, 2018)

El uso excesivo de smartphones también afecta a los pulgares. El Síndrome de lesión por esfuerzo repetitivo, por ejemplo, describe el dolor persistente en el pulgar. Esto se debe al hecho de que el pulgar está diseñado anatómicamente 
solo para contrarrestar a los otros dedos, pero no para el toque fino en la superficie de un teléfono inteligente. (Timm, 2014)

El neurólogo Hans-Peter Thier duda que exista el tema de la "demencia digital": "Bajo demencia la medicina comprende una pérdida de las habilidades cognitivas originalmente disponibles: una pérdida de la memoria, una limitación de la mente, desorientación y, en última instancia, una desintegración de la estructura de la personalidad. La demencia puede tener muchas causas. Un ejemplo es el daño cerebral debido a trastornos circulatorios. El denominador común de las causas son los cambios en la estructura y los procesos fisiológicos en el cerebro. Cualquiera que sea el uso de medios digitales en el cerebro, no hay evidencia de que conduzca a cambios patológicos tangibles en el cerebro". Thier dice que es imposible decirle a un cerebro si pertenece a un usuario de medios intensamente digital. (Lossau, 2013). Por el contrario, hay indicios de que navegar por Internet en personas mayores tiene un efecto positivo en la profilaxis del Alzheimer. Investigadores de la Universidad de Zúrich, sin embargo, encontraron en un estudio que el uso constante de consolas para videojuegos cambia el cerebro en la medida en que se usa con frecuencia la corteza somatosensorial. Esta asegura que el uso de un mando para videojuego modifica las áreas que son responsables de los dedos pulgar e índice. Este estudio ha sido efectuado gracias a la electroencefalografía. (Willems, 2014).

Los científicos de la facultad de Ciencias de la Vida Médica de la Universidad Furtwangen han adoptado la teoría generalizada de que las pantallas de los smartphones y las tablets pueden acumular varios tipos de gérmenes y bacterias patógenas, que amenazan la salud del usuario. Varias pruebas de laboratorio han demostrado que en promedio se recolectan alrededor de 100 tipos diferentes de bacterias dañinas no peligrosas. Así mismo un estudio realizado en Estados Unidos reveló que casi la mitad de todos los conductores entre 18 y 29 años utilizan Internet mientras conducen un automóvil. En el año 2010, 3092 personas murieron en Estados Unidos y 400,000 personas resultaron heridas porque el conductor estaba distraído. (Gomoll, 2012).

Los accidentes causados por la imprudencia de peatones también van en aumento. Cuando se lee la pantalla de un celular, la cabeza suele bajar y, por lo tanto, el enfoque de atención va solo en el dispositivo. Los peligros pueden ser 
de diversos grados, desde un tropiezo hasta un choque automovilístico. En el lenguaje juvenil, un peatón con este comportamiento se conoce como smombie, palabra que proviene de los términos smartphone y zombie.

Así mismo se han reportado en todo el mundo caídas a precipicios por tomarse selfies atrevidos, especialmente al borde de terrenos y barandas, así como accidentes de automóvil causados por querer filmar o fotografiar mientras se conduce.

\section{ii. Emocional}

La dependencia a la tecnología se puede considerar como hábitos y trastornos anormales del control de impulsos (F. 63.8) y el juego patológico (F. 63.0). Las opciones de diagnóstico y tratamiento son, por lo tanto, considerablemente más difíciles. Si bien la dependencia hacia la tecnología aún no se ha incluido en ningún sistema de clasificación, síntomas similares aparecen en otras dependencias mentales, aunque el deseo no se manifiesta de la misma manera en todas las personas. Reiner Obert establece una analogía con la dependencia del alcohol. (Obert, 2014).

La OMS ha asignado un número de código (6C51 Tech Disorder) en el borrador de la undécima revisión de la CID sobre la dependencia a la tecnología y los ha clasificado en el campo de los trastornos mentales, del comportamiento y del desarrollo neurológico. (OMS, 2015). Algunos expertos critican esta decisión y advierten contra el mal uso del diagnóstico. Por lo tanto, las personas afectadas tendrían que ser examinadas para detectar problemas como la depresión y los trastornos de ansiedad social. (Przybylski, 2018)

Un estudio realizado por El Instituto de Investigación Criminológica (KFN), encuestó a 44610 jóvenes de 15 en 61 condados alemanes seleccionados aleatoriamente y ciudades independientes. Encontró que más de 14,000 jóvenes ya son adictos a los juegos de computadora y otros 23,000 están en riesgo. Según el estudio, los adolescentes de 15 años que usaban World of Warcraft tenían un promedio de 3.9 horas de juego al día y la proporción de adolescentes con comportamiento adictivo con pérdida de control y abstinencia era del $8,5 \%$. (KFN, 2010). 
Una encuesta realizada en Estados Unidos en abril del 2007 por investigadores de Harris Interactive encontró que el 8,5\% de los 1,178 jugadores adolescentes "pueden ser clasificados como morbosos o clínicamente dependientes de los videojuegos". (Harris Interactive, 2007). Otra encuesta realizada en noviembre del 2006 en Reino Unido mostró que el 12\% de los 7,000 encuestados eran adictos. El 94\% de los jugadores entrevistados eran hombres. Uno de cada nueve jugadores cumplió con los criterios de adicción. (BBC News, 2006). Al otro lado del mundo, el gobierno de Corea del Sur encontró que el 2,4\% de los surcoreanos de entre 9 y 39 años son adictos, con un 10,2\% más de casos en el límite. (Washington Post, 2006)

Un estudio en el año 2008 por la Escuela de Medicina de la Universidad de Stanford mostró que la dependencia de los juegos por computadora es más pronunciada en los hombres que en las mujeres cuando el concepto del juego es sobre el control territorial. (Brandt, 2008). En un estudio de imágenes de la Escuela de Medicina de la Universidad de Stanford, los científicos han demostrado que durante un videojuego, los centros de recompensa del cerebro son más activos en hombres que en mujeres; "Estas diferencias de género pueden ayudar a explicar por qué los hombres se sienten más atraídos por los juegos de computadora y atrapados que las mujeres", escribieron los investigadores en su reciente publicación en el Journal of Psychiatric Research.

Con respecto a los smartphones, se ha creado un nuevo término: nomofobia: temor (separación) de ser inalcanzable para los contactos sociales y de negocios sin un teléfono móvil, un estudio en el Reino Unido mostró en el año 2008, que la mitad de sus habitantes poseedores de un teléfono móvil presentaban nomofobia. En el 2012 ya el $66 \%$ de los británicos se vieron afectados por este miedo. (Reuters, 2012)

\section{iii. Relación entre la tecnología y el comportamiento en niños de 10}

\section{a 12 años}

Los niños actualmente pasan tanto tiempo delante de la pantalla de un smartphone, tablet o consola como en la escuela. El riesgo de abuso estas tecnologías es particularmente alto para los niños con antecedentes de desventaja educativa. Los médicos también juegan un papel en la prevención. 
Los medios modernos se han extendido rápidamente y están reduciendo el tamaño del mundo al facilitar la comunicación en la escuela, el trabajo y el ocio hasta un punto que los hace indispensables. Por otro lado, son evidentes los riesgos, especialmente para los niños y adolescentes, que carecen de la competencia necesaria para utilizar los medios de manera inteligente. Los niños de familias más débiles a menudo abusan de los medios pasivos e interactivos a través del uso excesivo de estos medios, empeorando sus perspectivas futuras ya insatisfactorias. Las consecuencias somáticas, psicológicas y sociales del abuso crean un problema social que la atención médica debe enfrentar. (Przybylski, 2018)

Los términos "adicción a los medios de comunicación", "dependencia de los medios de comunicación" y "abuso de los medios de comunicación" han aparecido repetida y recientemente en periódicos de todo el mundo desde aproximadamente diez años. Como la investigación en esta área aún está "en pañales", no existe una definición válida universalmente. Además, la sintomatología aún no está clasificada como un diagnóstico clínico en directorios internacionales (ICD y DSM).

El consumo de medios se refiere al uso de medios de pantalla para el consumo pasivo, para jugar o para la comunicación. Los tipos de dispositivos (televisores, computadoras, consolas de juegos, teléfonos celulares) ahora permiten todos estos tipos de uso. Los siguientes criterios de diagnóstico para el abuso de los medios y la adicción a los medios como una definición de trabajo se basan en definiciones generales de adicción y dependencia de trastornos relacionados con sustancias y la definición de adicción a Internet. Para el abuso de computadoras e Internet, una orientación hacia el juego patológico (ICD -10, DSM-IV-TR) es alternativamente posible. (Obert, 2014).

En el año 2005, una cuarta parte de los escolares, la mitad de los niños y las dos terceras partes de los jóvenes tenían su propio televisor en su habitación, por lo que la proporción por género (varones, $41.8 \%$, niñas, $30.5 \%$ ), tipo de escuela y nivel de educación (nivel bajo). $57.3 \%$, alta $16 \%$ ). Tener televisión propia aumenta el tiempo de visualización diario de la televisión en una hora, duplica el consumo de películas con problemas de desarrollo (32.5 \% contra $15.5 \%$ ) y lleva a una subestimación del consumo de los padres. El control parental del consumo 
se correlaciona negativamente con el consumo de niños y adolescentes. Baja educación, obesidad, depresión y el estrés infantil. (ZDF Online Studies, 2005). Por el contrario, el uso de internet en adolescentes aumentó de un promedio de 6,3 a 97 minutos al día entre 1997 y 2006 (ZDF Online Studies, 2006). El comportamiento social disfuncional, la inteligencia social disminuida, la ansiedad social, la soledad, el estado de ánimo depresivo y la evitación de estrategias de resolución de problemas (huir de la realidad) se identificaron como factores de riesgo por el uso excesivo de Internet. En Estados Unidos, el $3.2 \%$ de los usuarios fueron clasificados como adictos y el $6.6 \%$ como vulnerables. El uso de PC también aumentó significativamente de cinco a 45 minutos por día entre 1997 y 2006.

Ser propietario de una consola de juegos varía según el género (niños $38.1 \%$, niñas $15.6 \%$ ) y educación de los padres (42.7\% bajo, $11.3 \%$ alto) y lleva a un aumento de cuatro veces en el consumo (20.2\% vs $6.6 \%$ ) de los juegos con problemas de desarrollo. En una encuesta, el $9.3 \%$ de los niños de 9 a 12 años de edad se consideraban usuarios excesivos de computadoras y videojuegos. Los factores de riesgo para el juego de pantalla, ya sea smartphones, consolas o por computadora, de modo excesivo identificaron ansiedad social, contacto social de baja calidad, apoyo social bajo para enfrentar el estrés, baja autoestima, entre otros. El $25 \%$ de los niños de 10 años y el $90 \%$ de los de 14 años ya son propietarios de teléfonos móviles. (ZDF Online Studies, 2017).

\subsection{Estado del arte}

\section{A. Antecedentes nacionales}

\section{El Pez en la Luna (2011)}

El Pez en la Luna es una organización que funciona para desarrollar en niños de 6 a 12 años habilidades físicas y emocionales a través de las artes expresivas: teatro, danza, actuación, etc. Durante más de 7 años Georgina Santibáñez, fundadora de El Pez en la Luna ha basado junto a su equipo las artes expresivas para promover la imaginación y creatividad en los niños. "El Pez en la Luna es una organización que agrupa educadores, artistas, psicólogos y terapeutas en artes expresivas (...) Trabajan con niños que hoy han perdido el espacio del juego, generándose una necesidad urgente de juego y arte para ellos" expresa la reportera Zoë Massey. 
El Pez en la Luna inició sus actividades en el 2011, en un contexto donde el niño actual no disfrutaba de sus momentos al aire libre sanamente. "En el auge de los videojuegos o del internet, estos niños solían pasar horas en el computador, no aprovechando la etapa tan linda como es la de la niñez" expresa Santibáñez, fundadora del proyecto. Actualmente El Pez en la Luna dispone de amplios espacios, ubicados en sus sedes de Surco, Magdalena y La Molina, en donde el niño puede divertirse sanamente.

Una de las ventajas y oportunidades que trae esta organización es que su equipo está constituido por profesionales expertos en temas como la infancia, la pediatría y las artes expresivas, por lo que es asegurado que el infante y sus apoderados se encontrarán bien asesorados.

\section{Operación Servir (2014)}

En el año 2014 la Asociación Scout del Perú se propuso recuperar espacios públicos en estado de abandono para que los niños, en su derecho a jugar, puedan divertirse libremente. Para ello diversas tropas de scouts de todo Lima actuaron en conjunto para que, con materiales reciclados como llantas, troncos y tubos, crearan estructuras lúdicas que beneficiaría a niños y niñas del sector. El proyecto se llevó a cabo en 5 zonas del distrito de San Juan de Lurigancho.

Este aporte a la sociedad hace un llamado de reflexión a que los niños tienen que jugar en espacios abiertos donde puedan desarrollar sus habilidades psicomotoras, socializar y actuar sobre valores como el respeto y la amistad. Así mismo, al reutilizar elementos reciclables, contribuyen al medio ambiente creando espacios eco-amigables.

La elaboración del proyecto duró 5 semanas, y contó con la participación de más de 150 scouts de diferentes distritos de la capital limeña, así mismo participaron de vecinos y voluntarios de la zona. Los resultados fueron muy beneficiosos para la comunidad. Una vez acabada la implementación se contempló de que niños y niñas efectivamente hacían uso del espacio lúdico, viéndose altamente beneficiados por este proyecto. Municipalidades aledañas al distrito como Independencia, Comas y El Agustino se inspiraron en este proyecto para también implementarlo en sus distritos. 


\section{Techo (2017)}

Techo es una ONG fundada en Chile en el año 2007, expandiéndose en países de Latinoamérica y El Caribe cuyo objetivo es erradicar la pobreza en zonas vulnerables de cada país. Viene operando en el Perú contando con sedes en Lima y Píura. Actualmente viene trabajando en más de 32 asentamientos humanos en el Perú.

Celebrando los 10 años de la organización, se realizó un proyecto, dirigido por la voluntaria Carla Arizmendi y con el apoyo de más de 50 voluntarios, el cual consistía en realizar una kermesse pro fondos para crear una biblioteca en el asentamiento humano "Bella Esperanza" ubicado en Manchay. Una de las actividades principales fue el de hacer torneo de juegos infantiles tradicionales, como jugar canicas, mundo, yaces, liga, soga, entre otros. El costo de la participación fue el de donar un libro en buen estado para que la biblioteca de Bella Esperanza pueda ser un deseo hecho realidad. Afortunadamente la actividad fue un éxito, con la participación de más de 100 personas, entre vecinos, voluntarios e invitados y la venta de pachamanca se logró recaudar los fondos presupuestados implementándose así la primera biblioteca en Bella Esperanza, para que niños, niñas y pobladores puedan verse beneficiados con ella.

\section{B. Antecedentes internacionales}

\section{Juguemos (2018) - Brasil}

Pensando en el rescate de los juegos de antaño, la Red de Solidaridad Marista, una organización perteneciente a la comunicad Marista en Brasil, con acciones en defensa de los derechos del niño y el adolescente, creó la plataforma "Juguemos". En el cual padres, madres y educadores tienen acceso a un paso a paso de las actividades infantiles y que se pueden poner en práctica tanto en casa, como en escuelas y en lugares públicos.

La pedagoga Vivian Aparecida, directora educativa de la Dirección Ejecutiva de Acción Social del Grupo Marista, afirmó que el objetivo fue crear un conjunto de juegos. "Durante el juego, el niño es protagonista de aquel momento y el libre juego accede la ingenuidad, la creatividad y la fantasía, las elecciones y los hallazgos. Incluso con el mundo cada vez más tecnológico y una variedad de 
equipos electrónicos a disposición, el niño decide cómo será el juego y cuáles son las reglas, estimula la imaginación, además de incentivar que exponga sus opiniones y defienda sus ideas ", evalúa.

El proyecto actualmente dispone de un sitio web en el cual se puede compartir los juegos del niño con otros usuarios de Internet. Para ello, basta con inscribirse en la plataforma, como explica la pedagoga Vivian Aparecida: "La persona necesita registrarse vía e-mail o vía Facebook, explicar el paso a paso y adjuntar un vídeo para detallar el juego Es muy intuitivo y fácil de compartir"

El objetivo del proyecto es el valorar la cercanía y el contacto del niño con los padres, abuelos, tíos, amigos, hermanos y otros niños. En un momento en que los familiares están cada vez más distantes y "esclavos" del tiempo, promover juegos entre ellos torna saludable y abre una posibilidad de diálogo más abierto entre padres e hijos.

\section{Kronstadt, capital de los juegos tradicionales (2015) - Rumanía.}

Con la intención de promover los juegos infantiles tradicionales en plena era digital, la Biblioteca Regional de Brasov, en Rumanía, creó un proyecto que se implementó tanto en nidos como en escuelas. Este proyecto fue financiado por gobiernos de Noruega, Islandia, el principado de Liechtenstein y por el Gobiernos de Rumania con aproximadamente 65,200 leu rumanos, a través de un programa de la Unión Europea que apoya la diversidad cultural.

Se organizó un evento con ayuda de psicopedagogos, docentes y demás involucrados el cual se desarrolló el viernes 2 de octubre del 2015. La actividad contó con alrededor de 400 niños y sus apoderados, los cuales llegaron al Coresi Shopping Resort para aprender y jugar juegos rumanos tradicionales en la cultura infantil como "La Stobor", "Halea-Malea", "Tzicul". Estos juegos se desarrollaban en equipos y entrenaban ciertas habilidades, incluso tenían que aprenderse viejos refranes. Los organizadores registraron a través de fotografías las costumbres y juegos de pobladores húngaros y transilvanos como evidencia de la diversidad cultural y étnica, así como para enfatizar que los juegos infantiles pueden ser un medio de comunicación muy simple y directa entre los grupos 
étnicos. Además de los juegos, también se establecieron talleres donde los niños podían armar muñecas de trapo, muñecos de dedos y otros juguetes de gran significado cultural.

\section{Juegos tradicionales para la protección del niño (2012) - Francia.}

Tierra de hombres es una ONG que desarrolló en Francia un manual mundial de los juegos infantiles tradicionales. Este manual con 16 juegos se realizó gracias a la experiencia adquirida por facilitadores de Moldavia y Albania. Basado en juegos tradicionales como "El zorro y las gallinas", "La ronda" o "Las escondidas" para niños de 4 a 14 años. El objetivo principal de este valioso manual fue el de fortalecer las habilidades para la vida, como cooperación, responsabilidad, flexibilidad, empatía, etc.; de los niños, así como el desarrollo de su capacidad de resiliencia y autoprotección.

El manual presenta una introducción que resume los beneficios de los juegos para la protección de los niños, los beneficios de juegos tradicionales, habilidades globales desarrolladas a través de juegos y un capítulo final para cada juego que contiene preguntas directamente relacionadas con temas de protección.

Este libro fue distribuido por toda Francia, en la cual facilitadores de todas las ciudades francesas encontrarán por cada juego una ilustración, una descripción, los objetivos físicos, emocionales y mentales y preguntas para realizar la retroalimentación al final del juego, con el fin de promover la participación infantil y libertad de expresión.

\section{CAPÍTULO IV}

\subsection{Estructura del proyecto}

\section{A. Concepto del proyecto}

El concepto del proyecto se basa en la alegría y dinamismo que evoca el ser niño. Estos conceptos tienen como objetivo el posicionar en la mente de los niños las sensaciones que el juego al aire libre conlleva. Los problemas asociados al sedentarismo tecnológico ocurren cuando el infante ve al aparato como única 
fuente de distracción, al no percatarse que hay un mundo lleno de experiencias al jugar al aire libre.

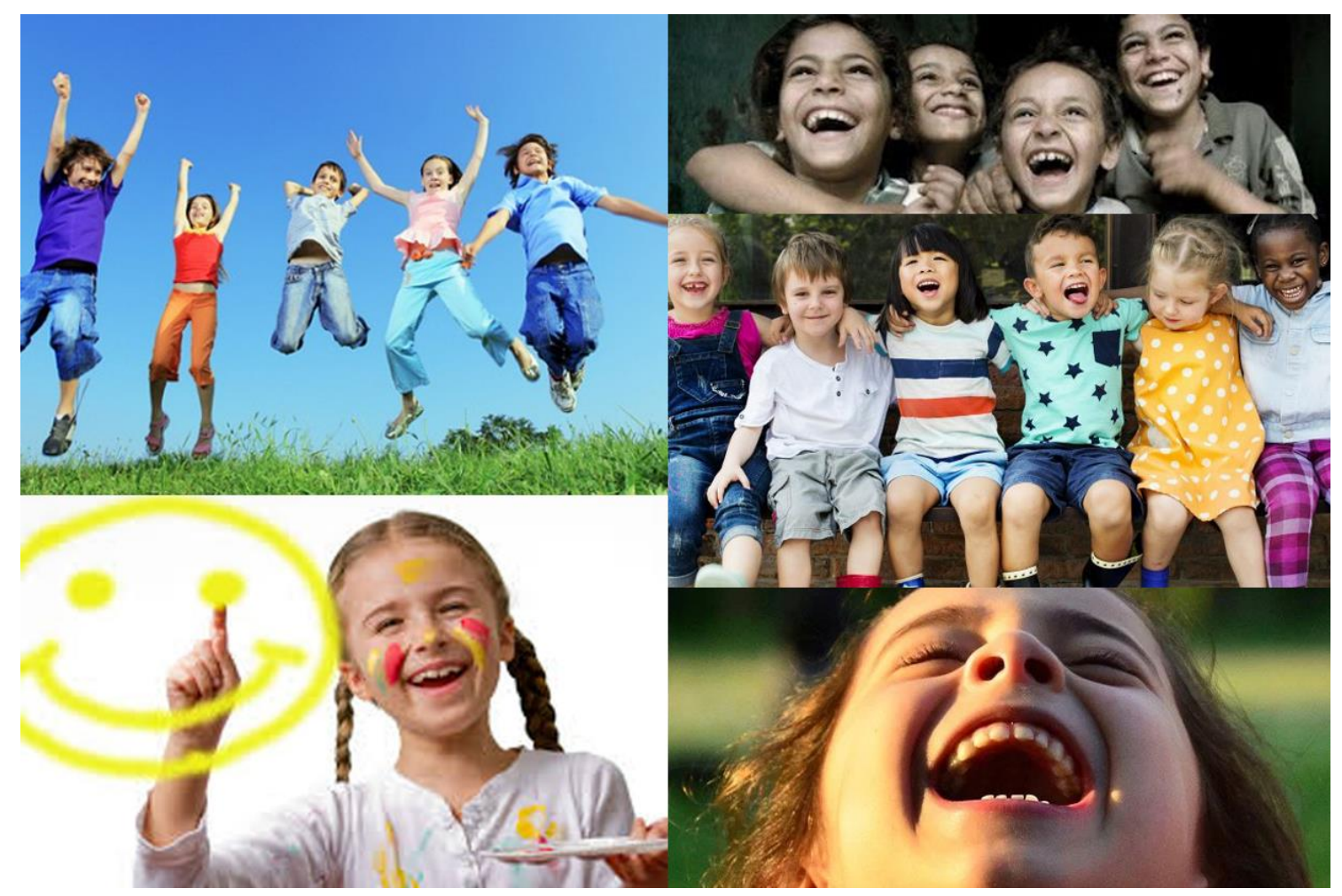

\section{B. Nombre del proyecto}

El nombre del proyecto es Chepi Bola, una frase que fue y es muy popular en el argot infantil. El término se usa por los niños cuando buscan pausar el juego, por lo que el título define la acción de pausar, darse un tiempo, stop, detener, alto. Crear una alerta para generar una pausa, reflexionar y tomar una acción que solucione un problema actual, en este caso, alertar que se está perdiendo los juegos tradicionales, los cuales han sido trasmitidos de generación en generación, y cómo la tecnología digital no solo ha desplazado estas tradiciones, sino también perjudicado la salud física y mental de los niños. El nombre del proyecto busca llegar a mi público objetivo con un mensaje de pausa, alerta y recordar.

\section{Fundamentación del proyecto}

Según una encuesta realizada por UNICEF Perú en el año 2017, el 85,3\% de los niños y niñas del Perú, los cuales fluctúan la edad de 6 a 12 años, usan sus 
dispositivos celulares únicamente para actividades de entretenimiento como descargar música, ver videos, jugar videojuegos, entre otros. Estas actividades se asocian al sedentarismo tecnológico infantil, los cuales dejan de lado el correr, reír y disfrutar de los juegos al aire libre. Así mismo causan problemas físicos, como la obesidad, la falta de coordinación y motricidad; y problemas emocionales como el aislamiento, la falta de empatía y la poca o nula comunicación interpersonal. Las consecuencias que acarrean la falta de juego sano en los niños se pueden ver reflejadas en la adolescencia y en la posterior adultez, manifestándose en la falta de habilidades físicas, emocionales y mentales.

Entidades nacionales e internacionales, como UNICEF, La Organización de Naciones, Save the Children, entre otras, encomiendan a la familia y a las instituciones educativas como responsables, los cuales se ven en el compromiso de impartir en sus enseñanzas valores que inculquen una sana convivencia en el niño y su entorno a través del juego al aire libre. Lo que antes era tan simple y natural en los niños, hoy necesita ser estimulado. Además de construir conocimiento y dar sentido al mundo, es en el juego, donde el niño resuelve problemas, lidia con reglas y amplía posibilidades comunicativas. Por estos motivos, jugar al aire libre es parte fundamental del desarrollo infantil.

El proyecto Chepi Bola nace de una preocupación al ver como el juego infantil tradicional, los cuales nos han traído muchas alegrías y buenos recuerdos, están siendo sustituidos por juegos virtuales en los cuales el niño desarrolla ociosidad y falta de empatía. El propósito de este proyecto es el de crear una memoria visual fotográfica, a través de un libro que demuestre que los niños nacidos en la década del 2000, por su naturaleza de ser niños, pueden también disfrutar del juego al aire libre, sin necesidad de estar conectados a un dispositivo tecnológico, siempre y cuando se les estimule al juego. Este libro contiene fotografías de una implementación en la cual se demostró visualmente las alegrías y habilidades de niños jugando juegos de antaño como yaces, soga, y mundo. Así mismo la meta a mediano plazo del proyecto es que el libro llegue a manos de padres de familia y maestros, los cuales tienen el compromiso de estimular en los niños los beneficios del juego al aire libre, siendo esta la vía adecuada. 


\subsection{Público objetivo}

\section{A. Actores involucrados en el problema}

Los actores involucrados en el problema son niños, los padres de familia, amigos de los hijos que pueden influenciar la moda de tener un celular o jugar videojuegos en consola, la municipalidad, el Ministerio de Educación y el Ministerio de Cultura. Los niños tienen entre 10 a 12 años y a pesar que son de sector socioeconómico $\mathrm{C} / \mathrm{D}$ poseen de un celular con internet. Vienen de familias en donde el diálogo familiar es poco o nulo, sin embargo, sí tienen un vínculo muy cercado con amigos, ya sea del barrio o del colegio, los cuales tienen influencia sobre ellos, sintiendo presión social. Estos amigos tienen intereses afines: juegan videojuegos como Fornite y usan aplicaciones musicales como TikTok. Estos niños se caracterizan por dejarse influenciar por las modas actuales sin darse cuenta que como niños deberían estar jugando al aire libre, generalmente son niños que se creen adolescentes. La familia es desinteresada, suelen ser familias monoparentales, en donde solo padre o madre convive con el menor. Los padres suelen tener un teléfono inteligente con acceso a internet, suelen dedicarse únicamente al trabajo dejando la crianza de sus hijos a terceras personas. No existe un tiempo "padre e hijo". La manera de que estos padres suelen demostrar el amor a sus hijos es pagándole los servicios básicos 0 comprándole algún incentivo cuando sea necesario. Estos padres de familia acostumbran estar estresados o irritados por la carga laboral y solo quieren llegar a la casa a descansar después del trabajo. Habitúan entrar al hogar, cenar y ver televisión. Son personas que usan como excusa el estar cansados como para poder pasar un rato con sus hijos. Actúan pensando en el momento y no suelen estar conscientes de lo que ocurre alrededor suyo, para ellos todo está bien. A pesar de todo esto, aman a sus hijos y darían la vida por ellos. En cuanto a los amigos del niño, tienen entre 10 y 15 años de edad, pertenecen al mismo sector socioeconómico. La situación de sus familias es igual: no hay comunicación con los padres y están jugando sólo las aplicaciones de moda, pudiendo pasar más de 3 horas usando el celular por día. Se creen adolescentes y copian las actitudes de chicos realities de la televisión o de influencers en Instagram. Suelen rechazar a niños que no compartan los mismos gustos y aficiones, se dejan guiar por estereotipos de la sociedad. 
Los ministerios de cultura y educación del Gobierno del Perú también son considerados como actores al ser estas entidades del estado que velan por la educación e identidad del alumnado, siendo estos en un futuro parte de la sociedad de todo un país.

\section{B. Fundamentación del público objetivo elegido}

Chepi Bola es un proyecto en el cuál se busca hacer una publicación editorial que rescate los valores, las tradiciones y el concepto que engloban los juegos infantiles tradicionales. El proyecto se enfoca en tener un libro que muestre el registro y evidencia de lo que significó los juegos de antaño. Por lo tanto, el público objetivo elegido fueron miembros del Ministerio de Educación y del Ministerio de Cultura, al ser estas entidades del estado que velan por la integridad física y mental de los alumnos, así también de su educación y de su identidad. Estos órganos del Poder Ejecutivos del Perú serán claves en el proceso de difundir, mediante el libro, una memoria fotográfica, la cual servirá para tomar consciencia de la situación y mantener viva en la memoria los juegos infantiles tradicionales.

\section{Descripción del público objetivo}

El público objetivo son miembros del Ministerio de Educación y Cultura, adultos que viven en Lima Metropolitana, que fluctúan de 30 a 60 años de edad, pertenecientes a un nivel socioeconómico A ○ B. Son personas con estudios superiores, que se han ganado el puesto de trabajar en un ministerio del Gobierno del Perú, generalmente son licenciados o han realizado ya una maestría o doctorado. En su mayoría, tienen vocación por servir al su patria a través de proyectos gestionados que fomentan cultura y buenas prácticas. Suelen trabajar con un equipo de profesionales altamente calificados y será mediante el trabajo grupal que logran sus objetivos. Suelen estar en búsqueda de ideas frescas para invertir en proyectos, en su mayoría sociales, para construir un Perú mejor. 


\section{CAPÍTULO V}

\subsection{Análisis del diseño}

\section{A. Simbolismo}

Chepi Bola presenta un isologotipo el cual tiene como elementos el logo, identificado por el texto "Chepi bola" y el isotipo, que es una reloj, la parte simbólica de la marca. El logo denota dinamismo, al tener una ligera inclinación hacia la derecha, lo cual evoca una percepción de movimiento y rapidez. Como elemento integrador rememorando a la infancia se presenta un reloj con una flecha en contra de sus manecillas, como isotipo. Este elemento es el símbolo universal de regresar en el tiempo, denota memoria, recuerdos y pasado: "Juguemos como antes". El isologotipo trasmite remembranza, de una manera no invasiva. Evoca a dar un viaje al pasado de la niñez del espectador, trasmitiéndote felicidad y nostalgia, pero a la vez dinamismo y conciencia.

A pesar de todo el desorden imaginario que puede causar hablar sobre juegos de la infancia en la calle, el estilo gráfico de esta campaña se distingue por ser limpio, ordenado, enérgico y de comunicación directa. Los trazos evocan a la memoria colectiva, es por eso que se prioriza al color blanco, el cual significa pureza, nostalgia, libertad, estimula la memoria y el pensamiento racional. Sin embargo también se da uso a colores vivos que denotan alegría infantil. Las tipografías seleccionadas reflejan la seriedad de la problemática en cuestión.

\section{B. Pragmatismo}

La pieza principal del proyecto es un libro el cual recopila fotografías tomadas el día de la implementación como testimonio gráfico que servirá para la posteridad como un aporte a conservar nuestras tradiciones. El libro se divide en dos capítulos, el primero habla del significado del juego al aire libre, los beneficios que estos trae, las habilidades mentales, físicas y emocionales que conlleva, así también cómo la tecnología y la seguridad ciudadana vienen afectando la manera en que los niños juegan; el segundo capítulo es mucho más visual, en la cual podemos apreciar a través de fotografías el proceso de 5 juegos tradicionales: mundo, yaces, soga, lingo y mata gente. Así mismo el segundo capítulo lleva consigo los testimonios de generaciones que jugaron estos juegos y sus opiniones que abarcan cómo en la actualidad los niños ya no disfrutan de 
estos juegos. Este libro se donará a la Biblioteca Nacional del Perú, al Ministerio de la Cultura y al Ministerio de Educación.

La implementación, evento clave del cual se sacarán las fotos para el libro, fue realizado en la Institución Educativa Jorge Chávez 6044, ubicado en Surco Pueblo. Contó con la participación de alumnos del sexto grado "A", los cuales rondan a edad entre 10 a 12 años. En esta implementación, con ayuda del tutor Alejandro Torres, se jugó al aire libre con los alumnos, los cuales exploraron los beneficios del juego sano.

\section{Estética}

El estilo gráfico se caracteriza por ser dinámico, ágil, amigable y limpio. Utilizando un lenguaje sencillo y ameno. Se hace uso de la fotografía como herramienta visual principal invitando al usuario a que se interese por el tema presentado. El estilo también denota alegría por la vida, dinamismo visual, siempre conservando el orden y la seriedad del problema principal.

\section{Sintaxis}

El isologotipo está compuesto por dos elementos básicos: el nombre del proyecto y la imagen. El nombre del proyecto es Chepi Bola, para lo cual se eligió una tipografía gruesa, alargada y sin serif, ligeramente cursiva. Lo cual le da relevancia y dinamismo. Al lado inferior izquierdo se encuentra la imagen de un reloj envuelto de una flecha que señala en contras las manijas, la que evoca la remembranza al pasado.

\subsection{Diseño de la comunicación}

El objetivo del proyecto es el de crear un libro que recopile a modo de fotografías de qué manera se jugaban los juegos infantiles tradicionales, así como el concepto detrás de estos, el contexto actual, la problemática del por qué ya no se juegan, etc. Para ello fue necesario realizar una implementación previa en un colegio, el cual se escogió estratégicamente teniendo en cuenta el nivel socioeconómico, la ubicación, cómo se relaciona la problemática, etc. Una vez acabada a implementación, se diseñó el libro "Juegos tradicionales" el cual tiene como meta a mediano plazo ser distribuido al Ministerio de Educación y Cultura, para que estas entidades puedan observar la problemática, analizar y ejecutar 
un plan de acción para que los beneficios del juego al aire libre sea de provecho por todos los niños y niñas del Perú.

Las fotografías, diagramación y la redacción del libro será visualmente impactante, por lo que se espera llamar la atención de nuestro público objetivo, así mismo el contenido del libro estará correctamente validado por un experto, por lo que cumplirá con todas las normativas correspondientes de un texto verificado.

La importancia y peso de los Ministerios en el Perú ayudarán a que el libro perdure con el tiempo, pues sirve de material gráfico y como memoria visual para que generaciones futuras observen y conozcan cómo jugaban generaciones pasadas. Así mismo servirá este libro de material de apoyo para que alguna entidad elabore y ejecute un plan de acción que pueda contrarrestar el sedentarismo tecnológico usando los beneficios de los juegos tradicionales. 


\section{CAPÍTULO VI}

\subsection{Análisis de los resultados}

\section{A. Aplicación}

Etapa I: Se escogió al colegio "Jorge Chávez 6044", perteneciente a la UGEL 07, ubicado en Jirón Grau 500, Santiago de Surco. En previas investigaciones realizadas como trabajo de campo se reveló que los alumnos del colegio, especialmente los de 5to y 6to de primaria, y la gran mayoría de los de secundaria, llevaban sus teléfonos celulares a la institución educativa, omitiendo las normas de convivencia y usándolos a su gusto. Al momento de ser encuestados los alumnos argumentaban que el motivo por el cual llevan sus celulares a la escuela es para comunicarse con su familia, ya sea papá, mamá o la persona que esté a su cargo, como medidas de seguridad. Sin embargo, muchos de ellos lo utilizan con el trasfondo de comunicarse con alumnos de otras aulas, escuchar música, jugar videojuegos, escuchar partidos de fútbol, coordinar encuentros en el baño del colegio e incluso para el uso del ciberbullying. A todo esto se realizaron registros fotográficos cuidando la identidad del alumno que no quería ser expuesto.

Etapa II: Una vez analizada la problemática del sedentarismo tecnológico y al percatarse que en los recreos el alumnado saca a escondidas su celular, no disfrutando de este momento de recreación fuera de las aulas, se analizó y planteó a los directivos del colegio el realizar una sesión de clases enfocada al juego al aire libre. Una vez aprobados todos los permisos correspondientes, y con ayuda del tutor del aula, el licenciado Alejandro Torres del Solar, el día miércoles 20 de marzo de 2019, a las 09:00 am se dio inicio a una sesión de clases, divida en dos horas. La sesión se realizó en el 6to grado "A". En el primer momento de la sesión de clases el profesor de Comunicación dio inicio mediante una reflexión sobre la importancia de los juegos al aire libre. Realizando las preguntas correspondientes al tema: “¿Qué actividades realizan en su tiempo libre?”, “¿Cuántas horas pasan en el celular?”, “¿Conocen los juegos tradicionales, como mata gente, 7 pecados y los yaces? ¿Los han jugado?”. La respuesta de los alumnos fueron variadas: las actividades realizadas en su tiempo libre iban desde salir con sus amigos al cine, ir a jugar fútbol e ir a las cabinas de internet; suelen pasar más de 2 horas al día en su celular y sí, la gran 
mayoría conocía de estos juegos, pero no los practicaba. En ese momento el profesor informó a los alumnos la visita de Ismael Josué León Matos, alumno de la carrera de Arte y Diseño Empresarial de la Universidad San Ignacio de Loyola. Luego de saludarlos, Ismael, gestor del proyecto "Chepi Bola", les explicó al alumnado acerca de los beneficios del juego al aire libre, así como las habilidades físicas, emocionales y mentales que acarrea jugar estos juegos.

Una vez acabada la teoría se llevó a los alumnos a la alameda del proyecto, para ejecutar la práctica. La alameda del colegio Jorge Chávez es un espacio donde se reúnen a la hora del recreo alumnos de todos los grados. Es un pasadizo amplio, rodeado de áreas verdes el cual desemboca a una gran cancha de deportes. Este espacio fue ideal para poder poner en práctica la implementación puesto que es un espacio que inspira libertad y dinamismo.

El objetivo de llevar a los alumnos a la alameda del colegio fue para que ellos puedan jugar 5 juegos tradicionales: mundo, mata gente, yaces, soga y lingo. Cada juego contaba con un facilitador, siendo 5 en total. Estos facilitadores estaban separados a lo largo de toda la alameda y eran fácil de distinguir, pues usaban un polo institucional con la marca del proyecto impresa en su vestimenta. Los facilitadores eran los responsables de explicar a cada grupo de alumnos las reglas del juego, así mismo se encargaban de que se respetaran las normas y de que el juego sea limpio. Así mismo velaban por la seguridad del alumno.

Una vez que los alumnos, acompañados del tutor y del gestor del proyecto, llegaron a la alameda, se dividieron en grupos de 5, para que puedan jugar cada juego tradicional y cada 7 minutos, luego del sonido de un silbato, ellos tenían que ir rotando, a manera de circuito, para que así puedan completar todos los juegos. Cada facilitador tenía cartillas y stickers los cuales se usarían con el objetivo de que el proceso sea más ordenado. Cabe señalar que el material de sogas, yaces, pelota, el diseño del mundo, ya estaban instalados en el espacio donde se realizaron estos juegos, así mismo los facilitadores estaban previamente capacitados para ejecutar sus acciones.

Se contó con la ayuda de dos fotógrafos profesionales, incluido el gestor del proyecto, para la toma de fotografías las cuales servirían en un futuro para el material visual del libro a presentar. 
La actividad se consideró un éxito, los alumnos, saltaban, seguían reglas, tomaban la iniciativa, y sobre todo se divertían. Se confirmó que el juego al aire libre los hacía interactuar entre ellos, compartiendo momentos gratos.

Para hacer una retroalimentación de la actividad realizada, una vez acabada esta los alumnos, el equipo de facilitadores, el tutor y el ejecutor se trasladaron hacia el aula, en donde se les otorgó tomatodos, diseñados con frases alusivas a lo divertido y sano que puede ser jugar al aire libre. También se les entregó una botella de agua y una lonchera nutritiva.

Para ver las opiniones y comentarios de la actividad vivida, el profesor Alejandro Torres les pidió a los alumnos hacer una reacción en una hoja de papel. Los comentarios fueron positivos en su totalidad, expresando gratitud, demostrando la comprensión de los beneficios del juego y afirmando que jugarán estos juegos a la hora de recreo.

\section{Etapa III}

A la semana siguiente, con el objetivo de consolidar la sostenibilidad a futuro en el colegio, se entregó al departamento de Tutoría para el bienestar del niño, una caja de plástico grande, con el logo del proyecto, que contenía elementos como sogas, yaces, pelotas, ligas, entre otros, para que los alumnos puedan pedirla y jugar a la hora de recreo.

Así mismo, con ayuda del personal de la institución educativa, se diseñó, trazó y pintó un mundo en un lugar estratégico para que alumnos de todos los grados puedan disfrutar del juego al aire libre.

10 días después de la implementación se visitó el colegio y gratamente se pudo corroborar que alumnos de diversos grados estaban jugando estos juegos tradicionales comprobando las reacciones favorables a la implementación.

\section{Etapa IV}

Con el material visual del registro de la problemática, la implementación y la post implementación, se realizó un libro de 66 páginas llamado “Juegos tradicionales", el cual se divide en dos capítulos. El primer capítulo habla del significado del juego, de los beneficios y las habilidades, como trabajar en equipo, la resolución de problemas, comunicación asertiva y de cómo la tecnología ha desplazado estos juegos tradicionales, siendo remplazados por videojuegos. Así mismo, este 
primer capítulo, habla del contexto actual de la seguridad ciudadana en la calle. El segundo capítulo del libro es mucho más visual, y en este se muestran 5 juegos tradicionales del día de la implementación y cómo se desarrollaron. En este capítulo habla de los siguientes 5 juegos: yaces, mundo, matagente, soga y lingo. Así mismo incluye testimonios de gente cuya infancia trascurrió en los años 70 y cómo en esa época se jugaban estos juegos y sus opiniones de la situación actual del juego infantil tradicional.

\section{B. Diseño de la metodología}

Para poder elaborar el proyecto se contó con el apoyo del personal del colegio Jorge Chávez. Directivos, psicólogos, el área de TOE (Tutoría para el bienestar de las niñas, niños y adolescentes) y personal docente, los cuales en conjunto ayudaron a plantear la metodología del proyecto. Estos profesionales lidian día a día con las diversas problemáticas en el alumnado, y son las personas ideales para saber el contexto en la cual se desenvuelve el alumno.

Se obtuvo una cita con la licenciada Marisol Medina, psicóloga del colegio desde el año 2007, la cual es testigo de cómo los avances tecnológicos han afectado la manera en la que los alumnos pasan su recreo. Esta profesional ha visto el cambio de cómo a medida que ha ido evolucionando el celular, también el tiempo al aire libre del alumno ha ido cambiando, volviéndolos más dependientes de la tecnología y apartándolos del juego al aire libre.

El licenciado Alejandro Torres, tutor y profesor de comunicación del aula en la que se desarrolló la implementación, fue también pieza clave en el desarrollo del evento. Pues gracias a su análisis crítico, brindó ideas para que el proyecto sea más viable, por ejemplo: el pintar un mundo en un lugar estratégico del colegio, para que la implementación presente sostenibilidad en el futuro; la cartilla y los stickers para que el proceso de la implementación sea mucho más ordenado, entre otras buenas ideas.

Así mismo se trabajó de la mano con la señora Clorinda Matos, auxiliar encargada del área de Tutoría para el bienestar de las niñas, niños y adolescentes, trabajadora del Colegio Jorge Chávez por más de 25 años y conocedora por experiencia del comportamiento del alumnado.

Se llegó a elegir la metodología del uso de los juegos tradicionales en la implementación porque, luego de charlas con el personal docente, los tutores y 
psicólogos especialistas, se llegó a la conclusión de que el juego es una actividad de placer, esencial e imprescindible para un buen desarrollo sensorial y cognitivo, por lo tanto, para potenciar todas las capacidades físicas y emocionales del niño, permitiéndole que interactúe con su entorno y con la realidad que lo rodea.

\section{Evaluación de la metodología}

Una vez acabada la implementación, en donde los alumnos jugaron juegos tradicionales: yaces, mata gente, mundo, soga y lingo; los alumnos redactaron en una hoja de papel sus experiencias de la actividad vivida. Se recolectaron 22 hojas escritas de las cuales los comentarios fueron positivos en su totalidad. "Mi experiencia fue increíble, porque jugué los juegos que siempre jugaba cuando era pequeño (...), estuvieron buenos todos los juegos pero el que más me gustó fue el mata gente. Para mí ha sido una buena experiencia que no voy a olvidar nunca", redacta el alumno Víctor Villanueva, como ejemplo de que la actividad cumplió los objetivos.

Visualmente se puede apreciar en las fotografías tomadas los rostros de felicidad de los alumnos al jugar al aire libre. En estas fotografías podemos apreciar como el niño resuelve problemas, lidia con reglas, interactúa con otros niños, explora diferentes movimientos y amplía las posibilidades comunicativas.

Luego de la implementación se realizaron entrevistas personales a 5 alumnos voluntarios, en las que comentaban frente a la cámara que esta actividad les ha servido para relacionarse más con alumnos los cuales no habían hablado nunca, estrechándose así nuevas amistades. Así mismo se hacen un compromiso personal que volverán a jugar estos juegos tradicionales en el futuro, a la hora de recreo.

Al día siguiente, con ayuda del personal de limpieza del colegio, se pintó un mundo, previamente diseñado, en un lugar estratégico del colegio. Se usó pintura de alto tránsito para que permanezca por varios años. Así mismo se entregó un envase de plástico considerablemente grande el cual contenía elementos como yaces, soga, ligas, pelotas, etc. Después de 10 días se volvió a visitar al colegio a la hora de recreo y efectivamente alumnos de todos los grados estaban saltando mundo, saltando soga y jugando yaces, comprobando las reacciones favorables al proyecto. 


\section{Registro de la implementación}

SOLICITO: PERMISO PARA DESARROLLAR IMPLEMENTACIÓN

JUEGOS TRADICIONALES.

Santiago de Surco, 8 de Marzo de 2019

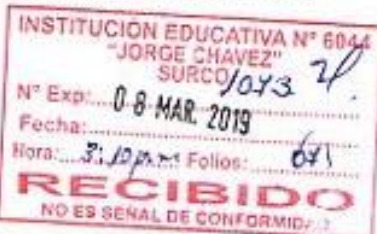

Señora

Lic. Raquel Ramos Centeno

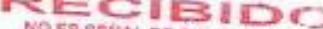

DIRECTORA DE LA INSTITUCIÓN EDUCATIVA "JORGE CHÁVEZ" - SURCO UGEL 07

Yo, Ismael Josué León Matos, identificado con DNI 73190921, con domicilio en Calle Loma Umbrosa 649, Santiago de Surco, estudiante de licenciatura de Arte y Diseño Empresarial de la Universidad San Ignacio de Loyola, solicito a su superior despacho lo siguiente:

Que, con el propósito de implementar mi trabajo de tesis acerca de LA PERDIDA DE LOS JUEGOS TRADICIONALES EN LOS NIÑOS Y ADOLESCENTES, solicito a su despacho que me otorgue el permiso correspondiente a fin de poder desarrollar el tema en la hora tutorial del docente tutor del primer año de secundaria en una sesión de clases en donde se tocaría el tema y los beneficios de poner práctica los juegos infantiles de antaño en la hora de recreo.

Es gracia que espero alcanzar por ser de justicia.

Atentamente,

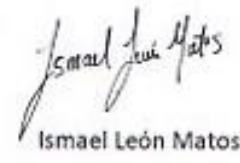

7319092

ADJUNTO FOTOCOPIA Y DNI,

ASI MISMO EL PROYECTO DE MI TESIS 

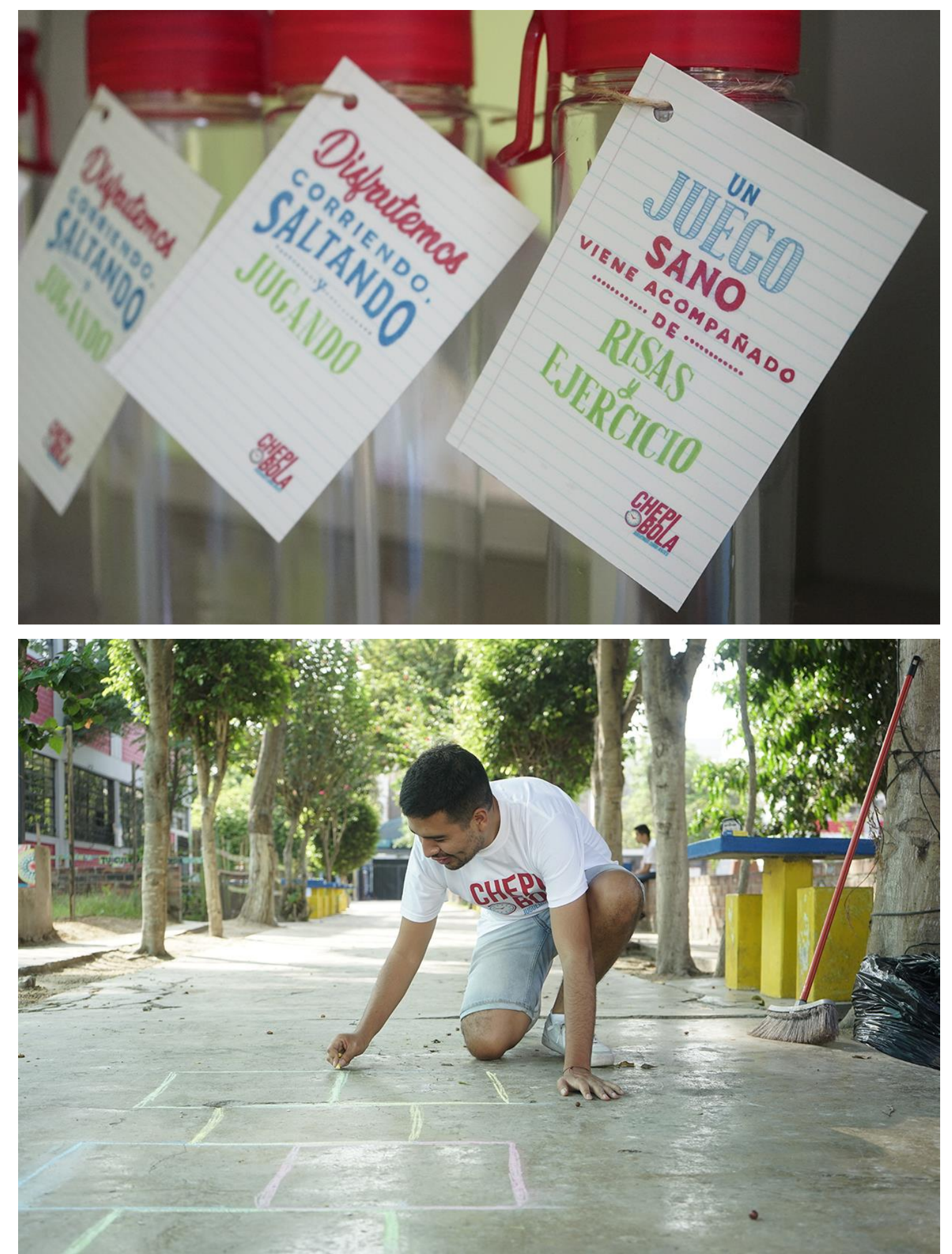

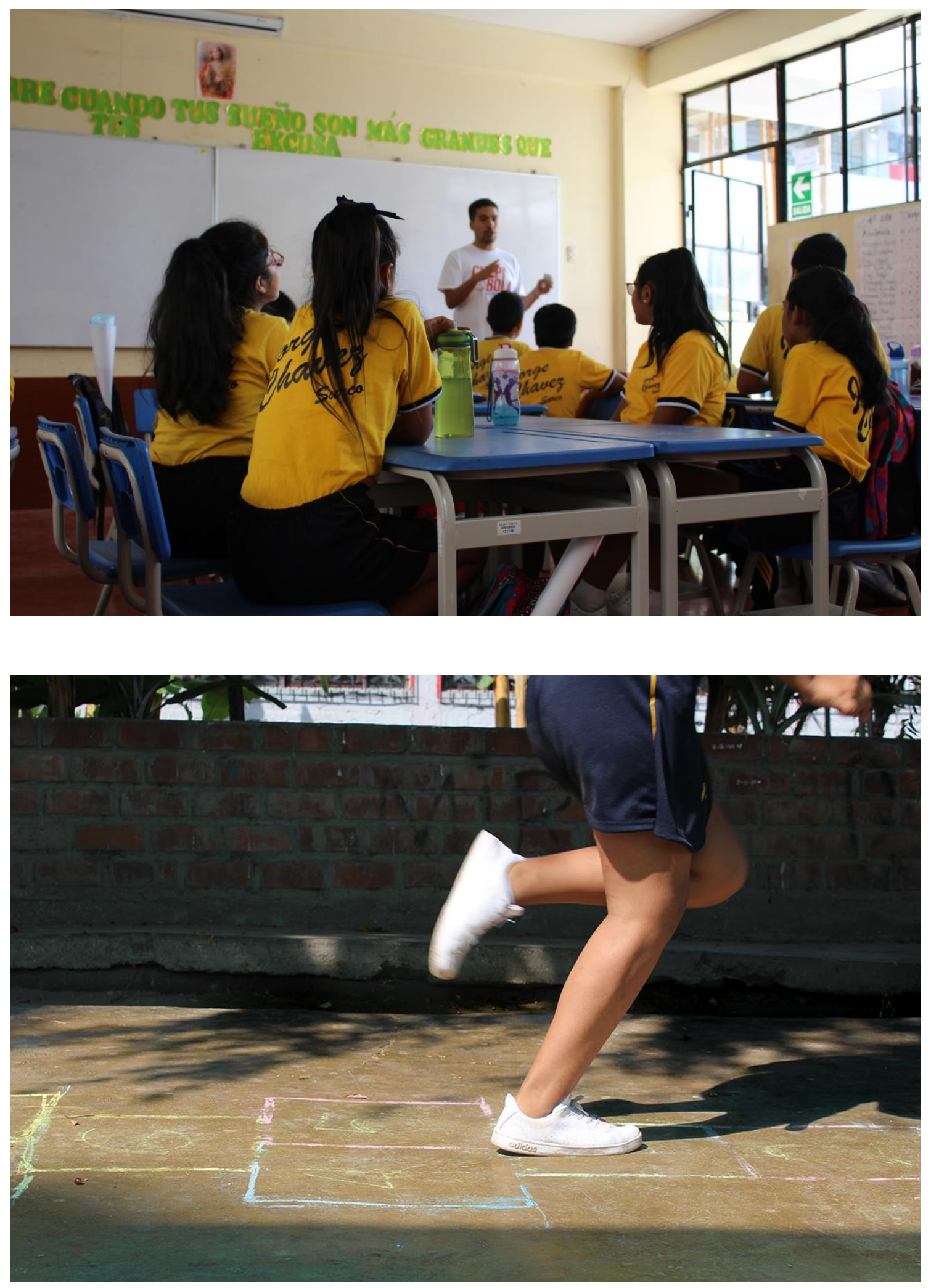

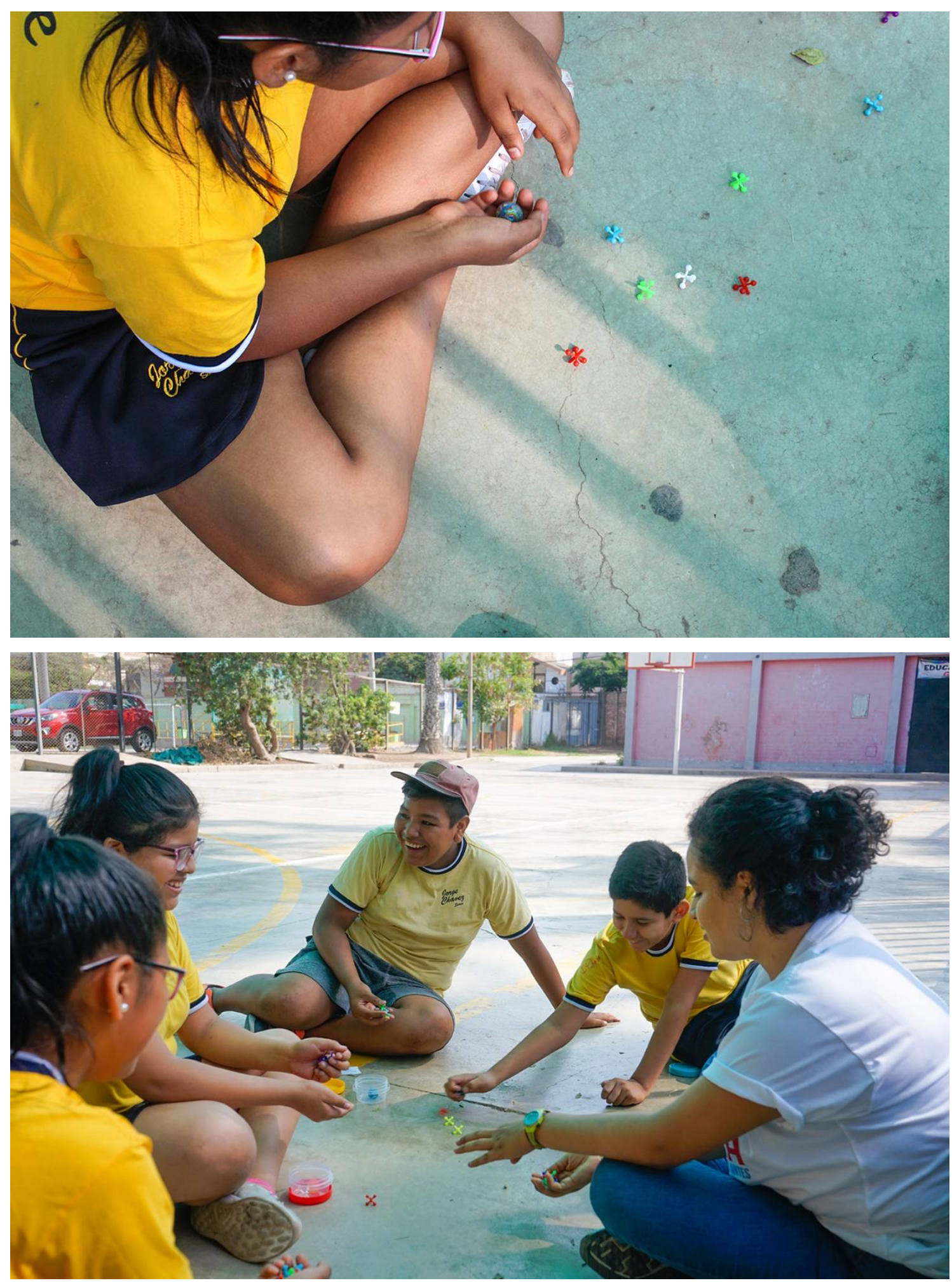

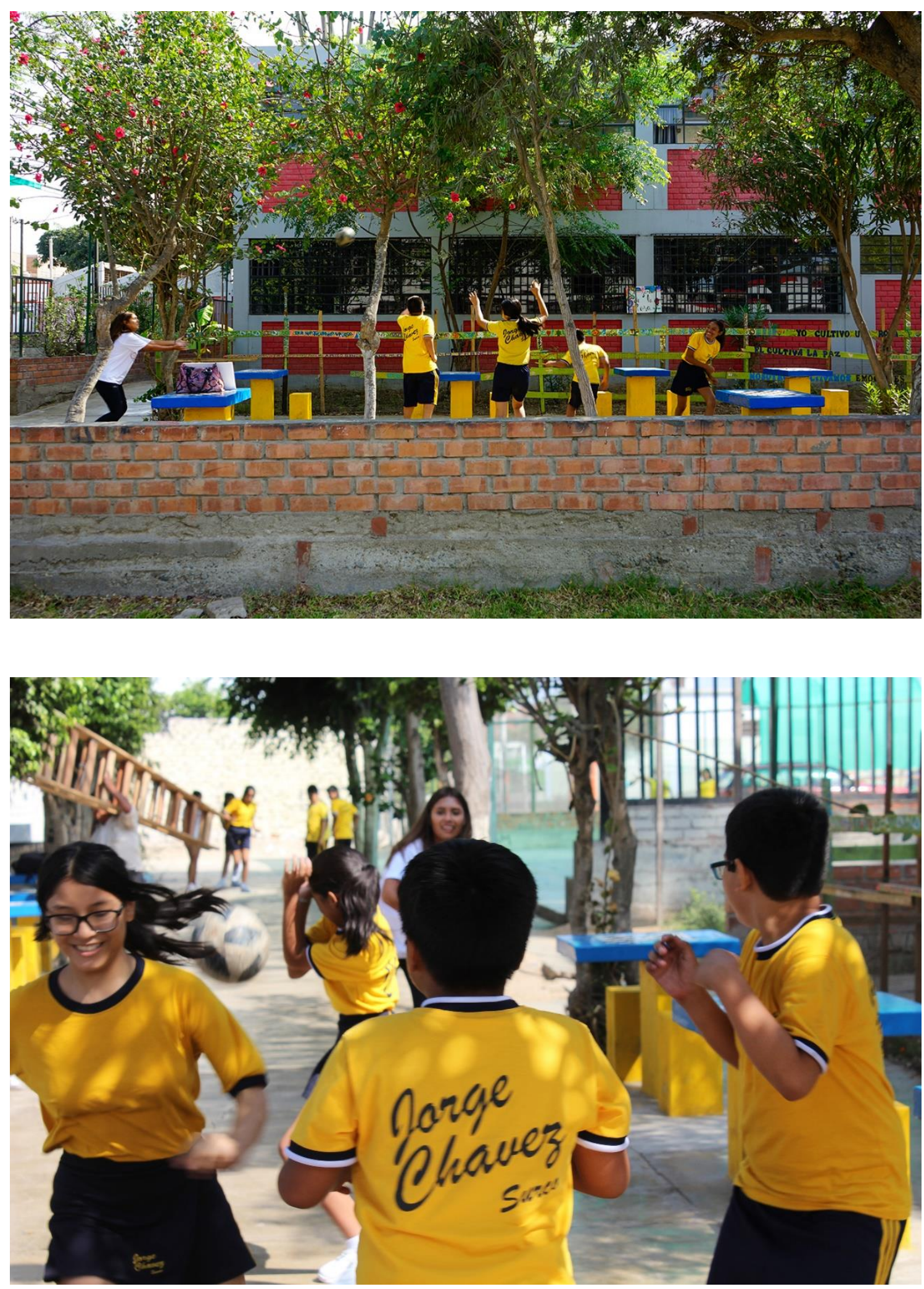

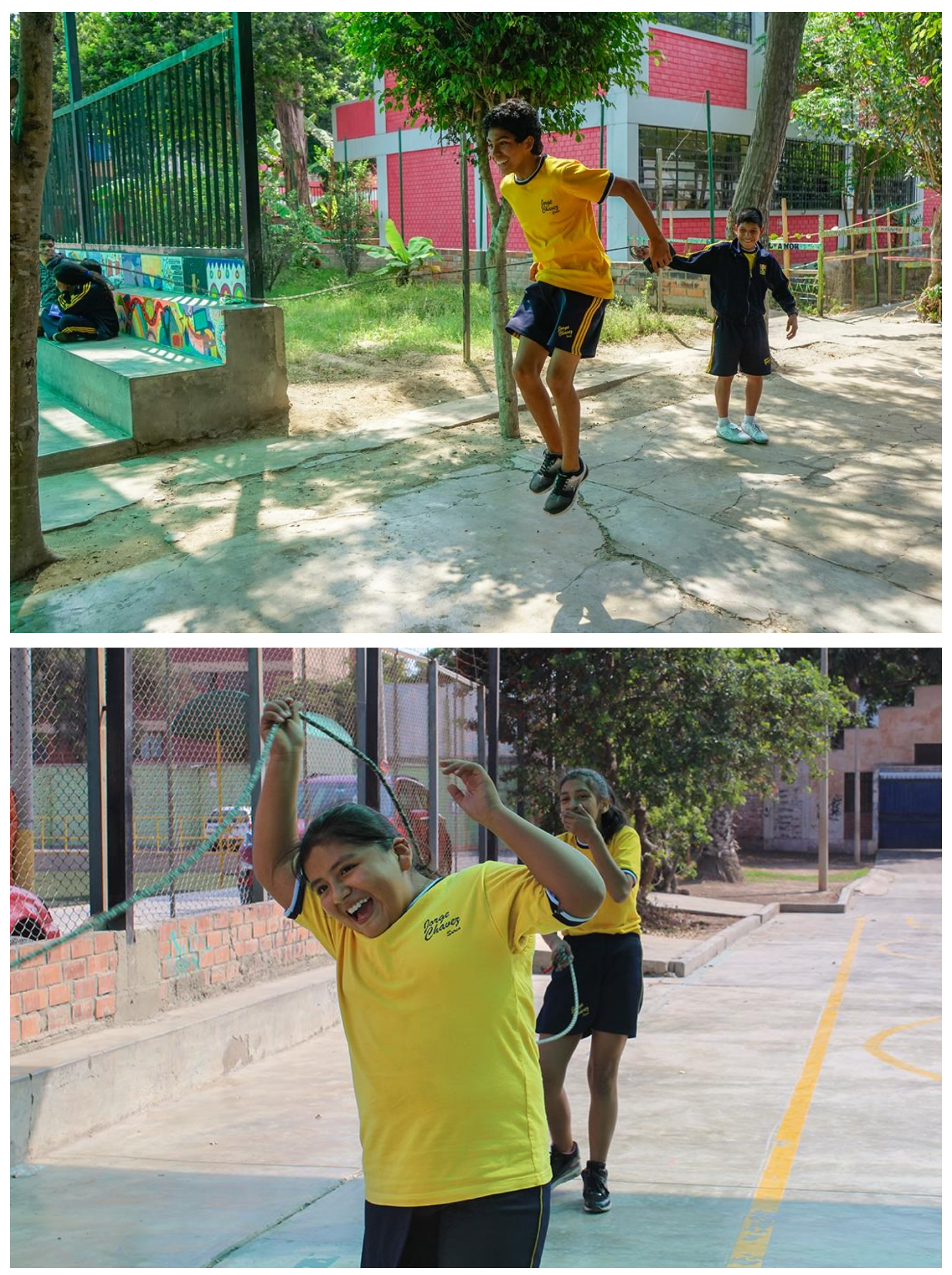

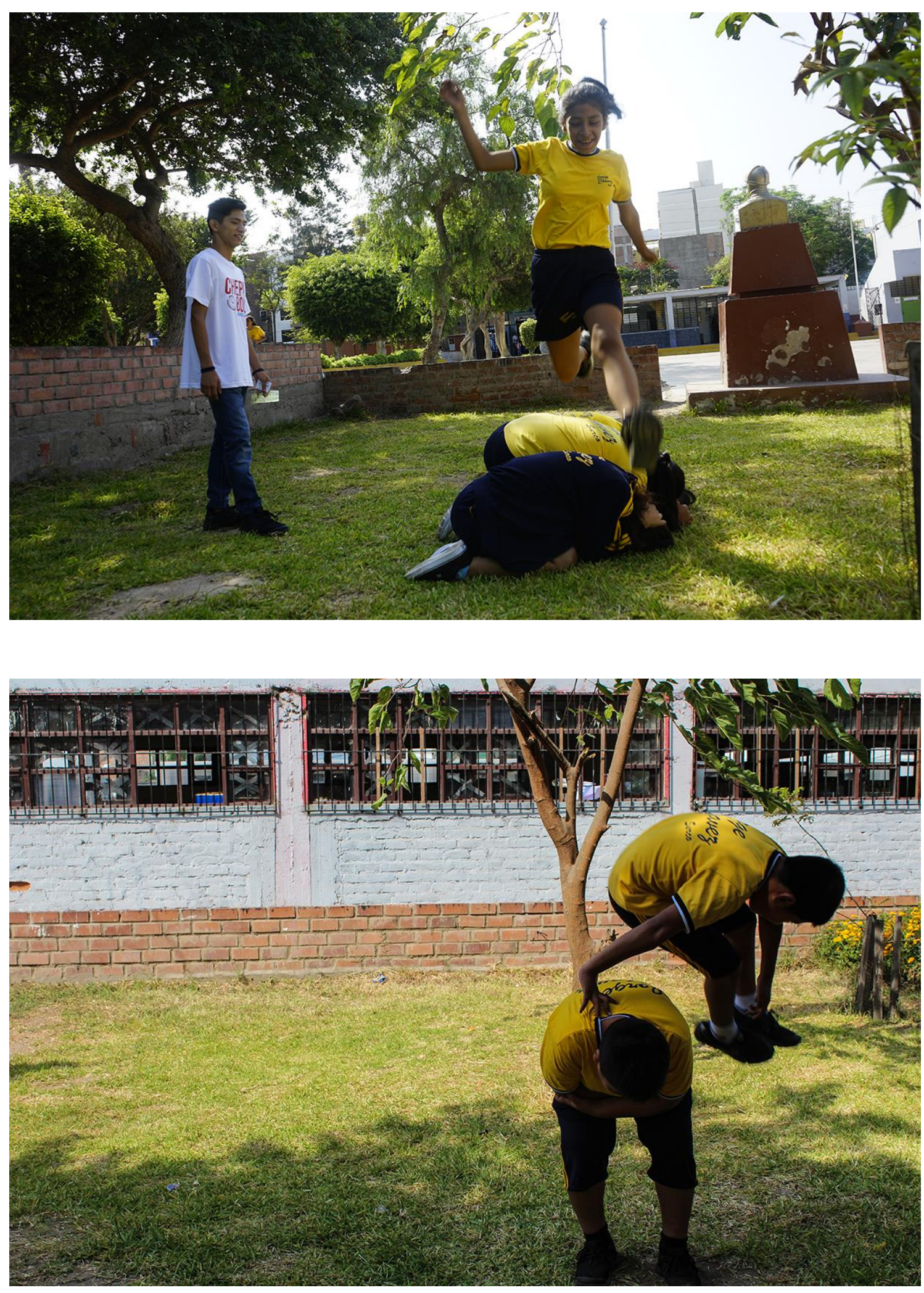

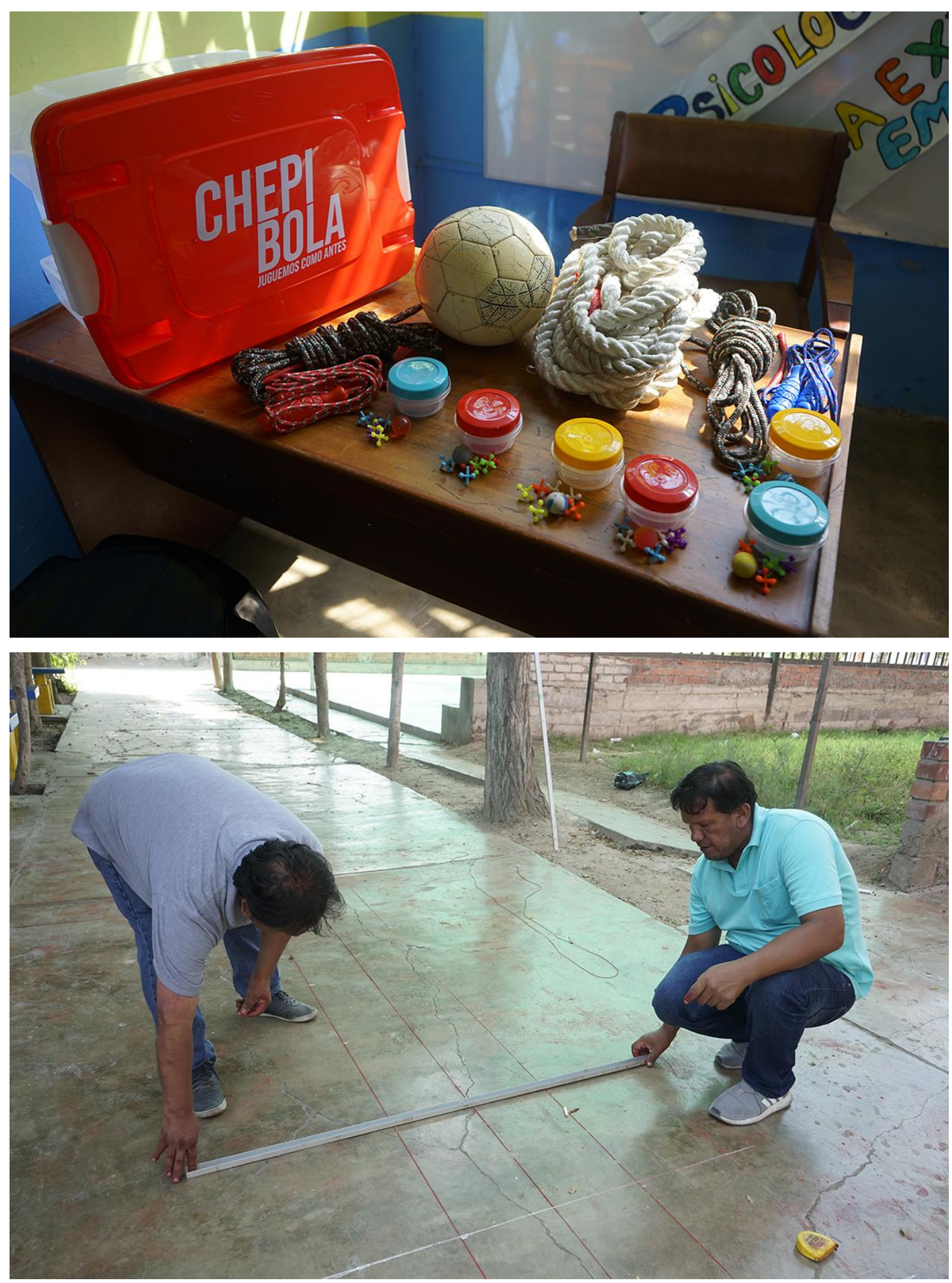


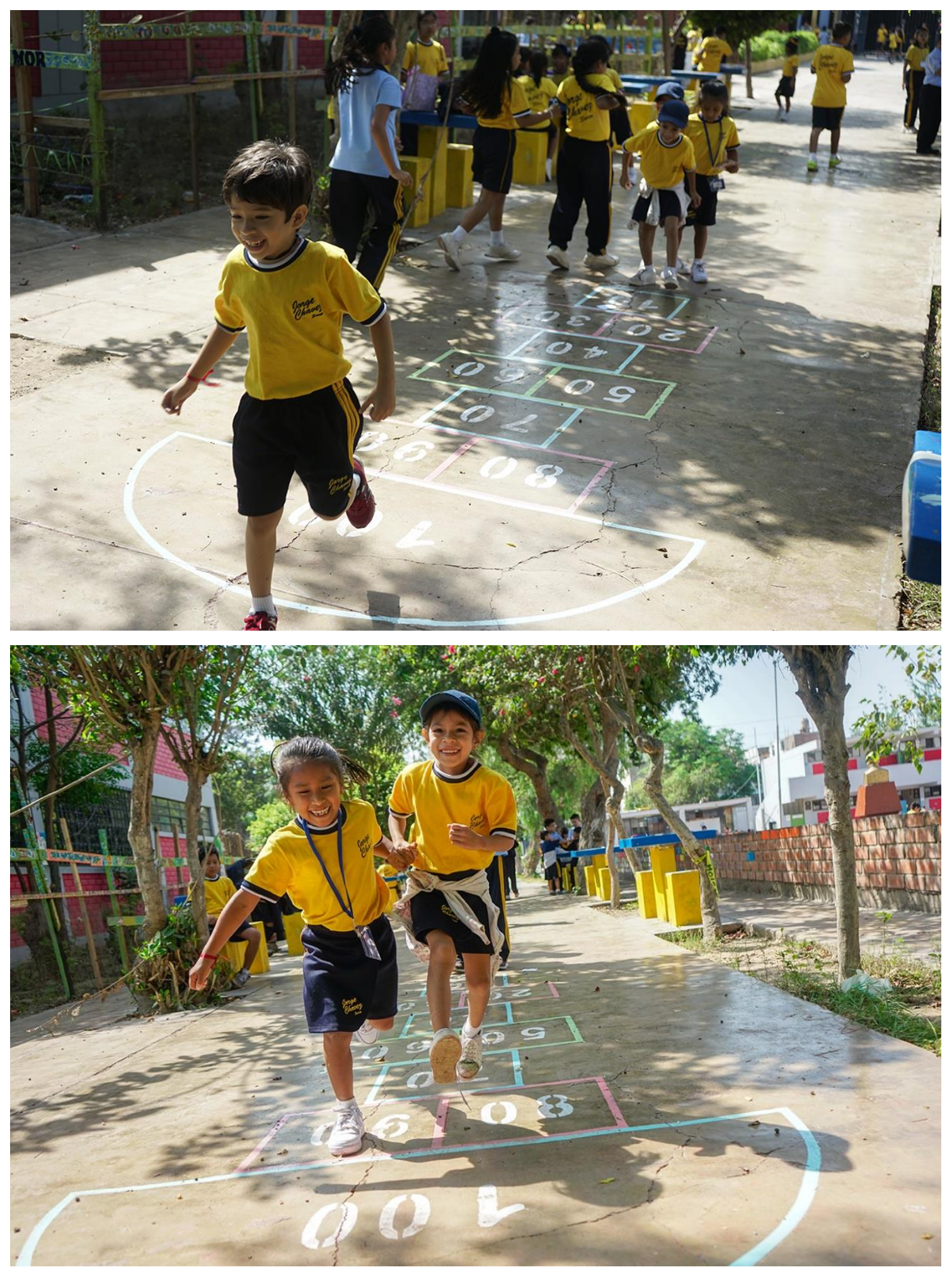




\section{F. Documentos que acrediten la evaluación de pares}

El proyecto Chepi Bola es una iniciativa realizada por el alumno Ismael León Matos, con el que compartí aulas en la Universidad San Ignacio de Loyola. Yo, Michelle Sánchez Mendoza, licenciada e Diseño Gráfico e identificada con DNI 70492261 testifico el compromiso y ardua labor con la que Ismael ha venido desarrollando este proyecto. Así mismo felicito que haya implementado con niños, los cuales son el futuro de nuestra sociedad.

\section{Michelle Sánchez Mendoza Licenciada en Diseño Gráfico 70492261}

Yo, María Lucero Canales Durand, licenciada en Diseño Gráfico por la Universidad San Ignacio de Loyola, doy fe de que el alumno Ismael León Matos, bachiller en Diseño Gráfico, identificado con DNI 73190921, viene realizando exitosamente el proyecto Chepi Bola. He sido testigo y consejera de su implementación, colaborando también en ella. El reforzar la identidad de un niño o niña, a través de juegos clásicos es una actividad que merece toda la atención, así mismo el velar por su salud física y mental es de vital importancia.

Como licenciada en Diseño Gráfico y conocedora del tema, afirmo que el recurso de la memoria fotográfica como registro visual es una idea viable y visualmente atractiva para que futuras generaciones puedan conocer cómo fueron estos juegos que muchos disfrutamos en nuestra infancia.

El diseño del libro ha sido pulcro, limpio y sobre todo directo, contando con texto citado y digerible. Las fotografías impecables. El manejo de la composición, iluminación y sobre todo velocidad se ve reflejada en la alegría y dinamismo de los niños.

\section{María Lucero Canales Durand Licenciada en Diseño Gráfico 47829765}




\section{CAPÍTULO VII}

\subsection{Conclusiones y recomendaciones}

- Es importante inculcar en las nuevas generaciones nuestras tradiciones culturales, ya sean festivas, culinarias o artesanales. Estas tradiciones se consideran parte fundamental para construir la identidad de una persona y de una sociedad. El trasmitir estas tradiciones, las cuales vienen de generación en generación es importante para vivir conscientes de nuestra riqueza cultural.

- A través de sus vínculos culturales, los juegos tradicionales tienen un impacto en reforzar la identidad del niño, además al jugarlos el niño desarrolla habilidades mentales, como ser creativos, el seguir instrucciones, encontrar soluciones; habilidades emocionales, como tomar iniciativa, compartir alegría, ser un buen perdedor; y habilidades físicas, como ser ágil, tener flexibilidad y desarrollar motora fina.

- Es innegable afirmar que la seguridad ciudadana en Lima, especialmente en los barrios populares, ha venido decreciendo en las últimas décadas. Los peligros están en todos lados. Es responsabilidad de nuestras autoridades el velar por nuestra integralidad física y la de nuestros niños. Sin embargo, el juego al aire sí es posible: en las escuelas. La hora de recreo es un momento ideal para que los infantes vuelvan a jugar los juegos de toda la vida. Bajo la custodia del personal docente el niño podrá jugar sanamente con toda seguridad.

- La comunicación interpersonal es de gran importancia para el infante. Con ella puede intercambiar ideas, compartir experiencias, expresar emociones. Sólo así el niño podrá manifestar sus deseos y convertirse en el futuro en un adulto emocionalmente estable.

- Los avances tecnológicos que acarrean este siglo son necesarios, al formar parte del desarrollo de toda una sociedad. No podemos negarle a un niño el usar dispositivos tecnológicos. Sin embargo, el menor de edad tiene que estar supervisados por un adulto responsable, toda vez que esta persona le va a establecer normas que incluye el contenido y tiempo frente a una pantalla. La 
definición del término "juego" ha cambiado en los últimos años. No se puede comparar el jugar un videojuego a jugar al aire libre.

El juego debe tomarse en serio, aplicando a todas las edades. Lo que antes era tan simple y natural en los niños, hoy necesita ser estimulado. Además de construir conocimiento y dar sentido al mundo, es en el juego, donde el niño resuelve problemas, lidia con reglas y amplía posibilidades comunicativas. Por estos motivos, jugar al aire libre es parte fundamental del desarrollo infantil. 


\section{Fuentes.}

Spaemann, R. (1952) El origen de la sociología desde el espíritu de la restauración. Alemania: Cascade Books.

Weber, M. (2014) Conceptos sociológicos fundamentales. Berlín: Alianza Editorial.

Giddens, A. (1993). Tradición en la sociedad post-tradicional. Londres: Social World

Shils, E. (1991). Tradición. Chicago: Universidad de Chicago.

Weick, K. (1995). Sensemaking en las organizaciones. Nueva York: Editorial Sage.

Herder, H (1933). Formas básicas de las normas sociales. Baviera: Editorial Herder.

Dundes, A (1980). Interpretando el folcklore. Indiana: Universidad de Indiana.

Sims, M \& Stephens, M (2005). Viviendo el Folckore: Introducción al estudio de la gente y sus tradiciones. Utah: Universidad Estatal de Utah.

Opie, I \& Opie P (1969). Juego de niños en la calle. Oxfordshire: Universidad de Oxford.

Georges, R (1995). Folkloristas. Indianapolis: Universidad de Indiana.

Dorson, R (1972). Introducción al folcklore. Chicago: Universidad de Chicago.

Degregori, C \& Portocarrero G (2005). Cultura y globalización. Lima: Universidad del Pacífico.

Rodriguez, G (2007). Ampay Perú. Lima: Editorial Aguilar.

Azcoyta, C (2008) "Historia de los orígenes de la gastronomía peruana". Consultado el 18 de febrero de 2019.

RPP Noticias (2017). “El Señor de los Milagros: Historia y Tradición” Consultado el 1 de marzo de 2019.

George, W (2004). Juego de niños. Massachusetts: Editorial SAGE. 
Asamblea General de las Naciones Unidas (1989). Convención sobre los Derechos del Niño; Artículo 31.1.

Elschenbroich, D (1979). El juego de los niños. Berlín: Editorial Zero.

Sawyer, K (2010). La historia del juego: creencias acerca del juego. Oxfordshire: Universidad de Oxford.

Empleados de Google y Apple prefieren escuelas sin computadores para sus hijos (2017). Consultado el 07 de abril de 2019 de https://www.mundonuevo.cl/empleados-de-google-y-apple-prefieren-escuelassin-computadores-para-sus-hijos/

Garaigordobil, M (1990). Juego y desarrollo infantil. Bilbao: Editorial Seco Olea. Frances, C (2009). La caída del juego. Georgia: Editorial Exchange.

Los niños ya no juegan en la calle (2018). Consultado el 07 de abril de 2019 de https://www.elcorreo.com/padres-hijos/educacion/ninos-juegan-calle-prefierenmovil-20181024104553-ntrc.html

Garvey, C (1985). El juego infantil. Madrid: Editorial Morata.

Williams, J (2009). 30 juegos al aire libre clásicos para niños. Buenos Aires: Editorial Wired.

Cosmo, V (2008). Producción y la enseñanza del saber. Paraná: Ministerio de Educación de Argentina.

Gaussot, L (2017). El juego del niño y la construcción social de la realidad. Paris: Editorial Le Carnet.

Instituto Nacional de Estadística e Informática; Censo 2017. Consultado el 7 de febrero de 2019.

Prost, A \& Vincent, G (1992). Historia de la vida: Desde la Primera Guerra Mundial hasta nuestros días. Denver: Editorial DU.

Lloyd, P (2009). Pueblos jóvenes en Lima: Aspectos de la urbanización en el Perú. Cambridge: Archivo CUP. 
Griffin, E (2011). Un primer vistazo a la teoría de la comunicación. Nueva York: Editorial McGraw-Hil

Castells, M (2009). Comunicación y Poder. Madrid: Alianza Editorial.

DeFleur, M \& Ball-Rokeach, S (2011). Teorías de la comunicación en masa. Rio de Janeiro: Zahar.

Williams, R (1992). Historia de la comunicación: del lenguaje a la escritura. Barcelona: Bosh Comunicación.

Rudiguer, F (2011). Las teorías de la comunicación. Porto Alegre: Editorial Artmed

Jakobson, R (2010). Lingüística y comunicación. Sao Paulo. Editorial Cultrix.

Mezquita, R (1997). La comunicación no verbal: relevancia para la práctica profesional. Lima. Editorial Aguila

Torres, M (2012). Psicología de la comunicación. Barcelona: Universidad de Barcelona.

Davis, Flora (1979). La comunicación no verbal. Sao Paulo: Summus.

Sousa, George (2006). Elementos de teoría y comunicación. Rio de Janeiro. Editorial Puerto.

Wels, A (2005). Conexión, comunicación y cultura. Buenos Aires: Editorial Flor Haythornthwaite, C \& Wellman, B (2002). Internet en la vida cotidiana: una introducción. Oxford: Editorial Blakckwell.

McQuail, D (2005) Teoría de la comunicación en masas. Londres: Publicaciones SAGE.

Jiang, C \& Hancock, J (2011) De la percepción al comportamiento: revelación de la reciprocidad y la intensificación de la intimidad en la comunicación por computadora. Londres: Publicaciones SAGE.

Dunn, R (2013). Teorías de la identidad y tecnología. Tennessee: Universidad Estatal de Tennessee. 
Bubas G \& Spitzberg, B. (2015) Las relaciones de las habilidades de comunicación. Consultado al 19 de febrero de 2019 de http://www.scielo.org.pe/scielo.php?script=sci arttext\&pid=S2219-

\section{$\underline{71682016000200001}$}

Crum, C (2012). Ventajas y desventajas de la comunicación mediada por computadora. Consultado al 19 de febrero de 2019 de

https://www.researchgate.net/publication/28083840 Los Estudios de Comuni cacion Mediada por Computadora una Revision y algunos Apuntes

Sobel, C \& Martin, I (2016). Distancia virtual: la tecnología está reescribiendo el libro de reglas para la interacción humana. Consultado el 19 de febrero de 2019 de https://bit.ly/2VvDaSB

International Data Corp. (2016). Consultado el 19 de febrero de 2019 de https://www.businessinsider.com/android-and-ios-continue-to-dominate-global-

\section{smartphone-market-2015-2}

Spitzer, M (2018). La epidemia de los teléfonos inteligentes. 7 tesis en la verificación de hechos. Berlin: Editorial GG

Jiang, M (2011). Estudio de la absorción de 63Ni (II) en bentonita unida a CMC de la Tecnología Móvil. Japón: Universidad de Kyoto.

Puricelli, $F$ (2011). La tecnología de transporte de principios del sigo XX y la creación de la cultura estadounidense moderna. (PDF). Consultado al 19 de febrero de 2019 a https://bit.ly/2Z18ZVA

Thurlow, C \& Tomic, A (2004). Comunicación mediada por ordenador: interacción social e internet. Londres: Publicaciones SAGE.

El teléfono fuera del reloj (2012), Consultado el 20 de febrero de 2019 de https://bit.ly/2ImqSrK

Vogt, Verena (2016). 100 por ciento lenguaje juvenil. Munich: Langenscheidt.

Shepherd, I (2010) La dependencia de los videojuegos en la infancia y la adolesencia. Hannover: Instituto de Investigación Criminológica de Baja Sajonia. 
BBC News ¿Qué dicen los jugadores en línea? (2006). Consultado el 20 de febrero de 2019 de

http://news.bbc.co.uk/2/hi/uk news/england/nottinghamshire/6193462.stm 